Prepared in cooperation with the Maine Geological Survey

\title{
Groundwater Recharge Estimates for Maine Using a Soil-Water-Balance Model-25-Year Average, Range, and Uncertainty, 1991 to 2015
}
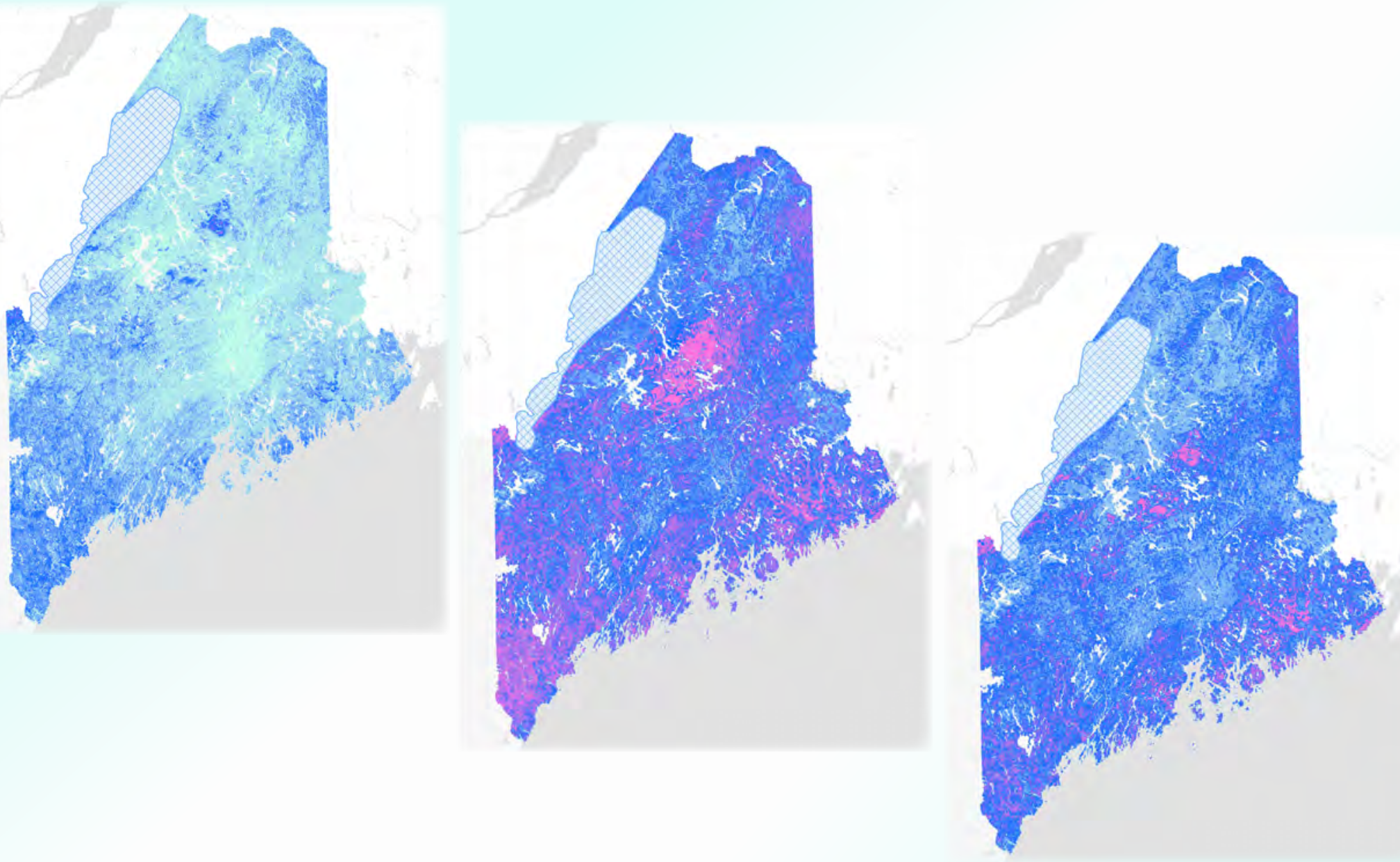

Scientific Investigations Report 2019-5125 
Cover. Base map of figures 17 (left), 18 (middle), 16 (right) from this report. 


\section{Groundwater Recharge Estimates for Maine Using a Soil-Water-Balance Model-25-Year Average, Range, and Uncertainty, 1991 to 2015}

By Martha G. Nielsen and Stephen M. Westenbroek

Prepared in cooperation with the Maine Geological Survey

Scientific Investigations Report 2019-5125 


\title{
U.S. Department of the Interior \\ DAVID BERNHARDT, Secretary
}

\author{
U.S. Geological Survey \\ James F. Reilly II, Director
}

U.S. Geological Survey, Reston, Virginia: 2019

For more information on the USGS — the Federal source for science about the Earth, its natural and living resources, natural hazards, and the environment—visit https://www.usgs.gov or call 1-888-ASK-USGS.

For an overview of USGS information products, including maps, imagery, and publications, visit https://store.usgs.gov/.

Any use of trade, firm, or product names is for descriptive purposes only and does not imply endorsement by the U.S. Government.

Although this information product, for the most part, is in the public domain, it also may contain copyrighted materials as noted in the text. Permission to reproduce copyrighted items must be secured from the copyright owner.

Suggested citation:

Nielsen, M.G., and Westenbroek, S.M., 2019, Groundwater recharge estimates for Maine using a Soil-Water-Balance model-25-year average, range, and uncertainty, 1991 to 2015: U.S. Geological Survey Scientific Investigations Report 2019-5125, 56 p., https://doi.org/10.3133/sir20195125.

Associated data for this publication:

Nielsen, M.G., 2019, Soil-Water-Balance (SWB) model archive used to simulate potential annual recharge in Maine, 1991-2015: U.S. Geological Survey data release, https://doi.org/10.5066/P9GRP7DH.

Nielsen, M.G., and Westenbroek, S.M., 2019, Simulated 25-year median potential recharge datasets for Maine, 1991-2015: U.S. Geological Survey data release, https://doi.org/10.5066/P9052ULY.

ISSN 2328-0328 (online) 


\section{Contents}

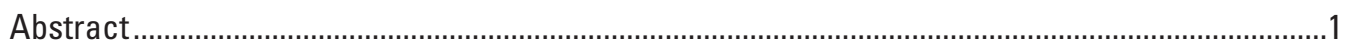

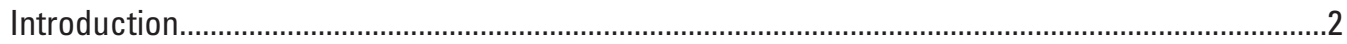

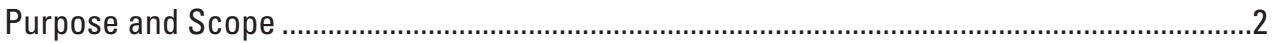

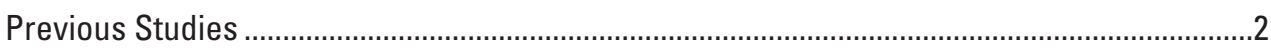

Use of the Soil-Water-Balance Model for Regional-Scale Recharge Estimation ............2

Description of Study Area .................................................................................................

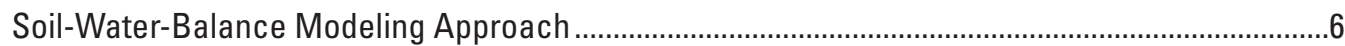

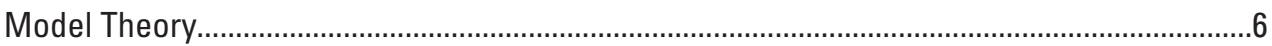

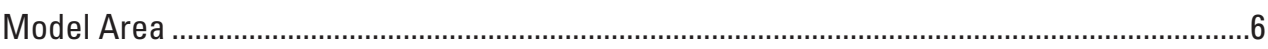

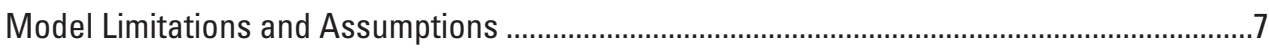

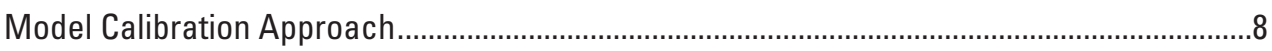

Processing of Calibrated Model Output.................................................................................

Model Uncertainty Representation ..............................................................................................

Maine Soil-Water-Balance Model Description and Calibration.........................................................

Model Input Data Summary ..............................................................................................

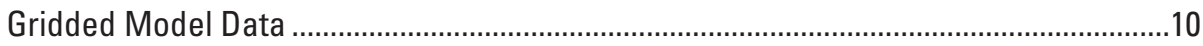

Lookup Tables and Control File .....................................................................................16

Calibration of Maine Soil-Water Balance Model ................................................................16

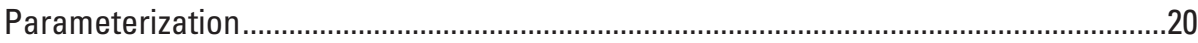

Calibration Targets and Weights ................................................................................

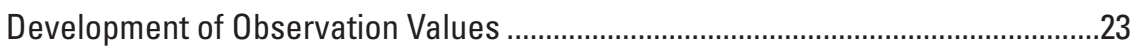

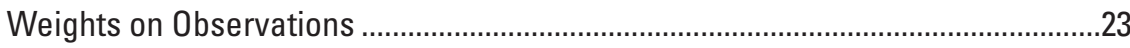

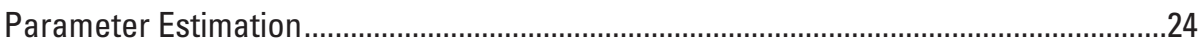

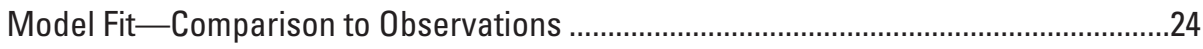

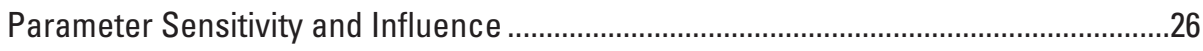

Groundwater Recharge Estimates for Maine, 1991-2015 …………………………....................30

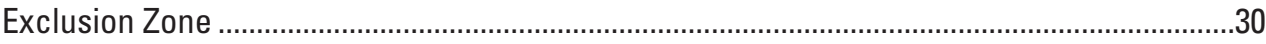

Recharge Grids-Annual Average and 25-Year Minimum, 25-Year Maximum

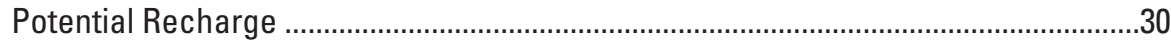

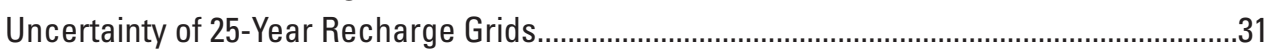

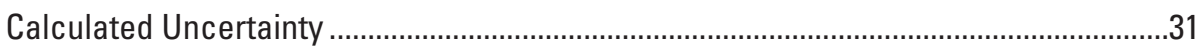

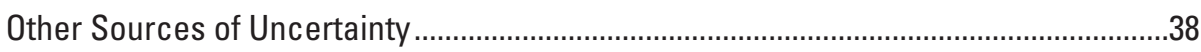

Comparison of Average Recharge to Previous Studies ..........................................................38

Estimated 25-Year Potential Recharge Statistics and Ranges for Calibration

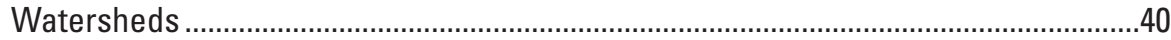

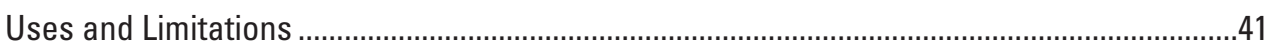

Appropriate Uses and Example Use Application ..........................................................43

Limitations to the Availability and Use of the Potential Recharge Grids.........................43

Summary and Conclusions.....................................................................................................

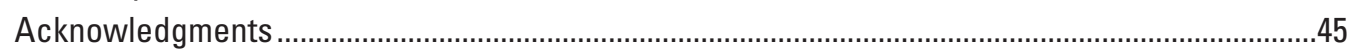

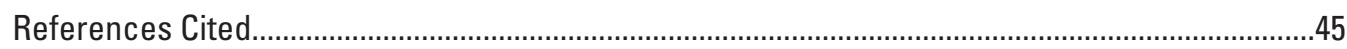

Appendix 1 Details of Soil-Water-Balance Model Input for Maine ............................................50

Appendix 2 Details of Soil-Water-Balance Model Calibration Information ..................................53

Appendix 3 Annual Values of Modeled Recharge, Runoff, Evapotranspiration, and Precipitation for Calibration Watersheds, 1991-2015 …………………………………......56 


\section{Figures}

1. Map showing calibration watersheds used in the Maine Soil-Water-Balance model and location of the study area.

2. Diagram showing operation of daily Soil-Water-Balance calculations and water-balance output.

3. Map showing land use for the Maine Soil-Water-Balance model and calibration watersheds

4. Map showing hydrologic soil groups of the Maine Soil-Water-Balance model and calibration watersheds

5. Graph showing the abundance of land use class:hydrologic soil group categories for the top 35 categories in the Maine study area..

6. Map showing available water capacity of the Maine Soil-Water-Balance model and calibration watersheds

7. Histograms showing the distribution of available water capacity values for each hydrologic soil group in the Maine Soil-Water-Balance model

8. Map showing DayMet average annual precipitation, 1991 to 2015, for the Maine Soil-Water-Balance model and calibration watersheds

9. Map showing Parameter-elevation Regressions on Independent Slopes Model (PRISM) normal annual precipitation 1981 to 2010, for the Maine Soil-Water-Balance model and calibration watersheds

10. Graphs showing overall model calibration results.

11. Graphs showing relations between observed and simulated values for watershed recharge, runoff, and evapotranspiration for 32 calibration watersheds during 2000-12, and plots of residuals compared to observed values........26

12. Graphs showing annual comparisons of observed and simulated recharge, runoff, and evapotranspiration for 2001-12 in six calibration watersheds

13. Graphs showing the identifiability of the top 40 most-sensitive parameters used in the Parameter ESTimation model calibration, by parameter group (appendix 2)........29

14. Histograms showing range of 25-year modeled mean, median, minimum, and maximum potential annual recharge across Maine

15. Map showing simulated 25-year mean annual potential recharge to groundwater for Maine, 1991 to 2015

16. Map showing simulated 25-year median annual potential recharge to groundwater for Maine, 1991 to 2015

17. Map showing simulated 25-year minimum annual potential recharge to groundwater for Maine, 1991 to 2015

18. Map showing simulated 25-year maximum annual potential recharge to groundwater for Maine, 1991 to 2015

19. Map showing calculated standard deviation on the median annual potential recharge to groundwater for Maine, 1991 to 2015

20. Histogram showing the distribution of the calculated standard deviation of the potential median annual recharge.

21. Plots showing highest and lowest median annual potential recharge by land-use class:hydrologic soil group category, with standard deviations

22. Graph showing a comparison of previously published annual average recharge values in a selection of study areas in Maine, and corresponding median potential annual recharge from the Maine Soil-Water-Balance model, with 95 -percent confidence intervals calculated from the standard deviation grid 


\section{Tables}

1. Calibration watersheds used in the Maine Soil-Water-Balance model and associated streamgage information................................................................................

2. Land-use classes for the Maine Soil-Water-Balance model...........................................8

3. Hydrologic soil groups used in the Maine Soil-Water-Balance model ...........................12

4. Percentage of Maine Soil-Water-Balance model and calibration watersheds covered by each combination of land-use class and hydrologic soil group..

5. Example land-use lookup table for runoff curve numbers, maximum recharge rate, interception, and rooting zone depths used by the Soil-Water-Balance model.....21

6. Example irrigation lookup table for plant growth settings and bare soil evapotranspiration used by the Soil-Water-Balance model.............................................22

7. Identifiability of parameters and parameter groups for the Maine Soil-Water-Balance model.

8. Median potential annual recharge rates and standard deviation for the highest and lowest 10 land-use class:hydrologic soil group categories in the Maine Soil-Water-Balance model...

9. Median and mean estimated annual potential recharge rates for the 20 most-abundant land-use class:hydrologic soil group categories in the Maine Soil-Water Balance model

10. Annual potential recharge statistics calculated for Soil-Water-Balance model observation watersheds

11. Example of calculations for a watershed using the annual potential recharge grids in Maine. 


\section{Conversion Factors}

U.S. customary units to International System of Units

\begin{tabular}{|c|c|c|}
\hline Multiply & By & To obtain \\
\hline \multicolumn{3}{|c|}{ Length } \\
\hline inch (in.) & 2.54 & centimeter $(\mathrm{cm})$ \\
\hline foot $(\mathrm{ft})$ & 0.3048 & meter $(\mathrm{m})$ \\
\hline mile (mi) & 1.609 & kilometer (km) \\
\hline \multicolumn{3}{|c|}{ Area } \\
\hline square mile $\left(\mathrm{mi}^{2}\right)$ & 259.0 & hectare (ha) \\
\hline square mile $\left(\mathrm{mi}^{2}\right)$ & 2.590 & square kilometer $\left(\mathrm{km}^{2}\right)$ \\
\hline \multicolumn{3}{|c|}{ Flow rate } \\
\hline cubic foot per second $\left(\mathrm{ft}^{3} / \mathrm{s}\right)$ & 0.02832 & cubic meter per second $\left(\mathrm{m}^{3} / \mathrm{s}\right)$ \\
\hline inch per year (in/yr) & 25.4 & millimeter per year (mm/yr) \\
\hline \multicolumn{3}{|c|}{ Hydraulic conductivity } \\
\hline foot per day (ft/d) & 0.3048 & meter per day $(\mathrm{m} / \mathrm{d})$ \\
\hline
\end{tabular}

Temperature in degrees Fahrenheit $\left({ }^{\circ} \mathrm{F}\right)$ may be converted to degrees Celsius $\left({ }^{\circ} \mathrm{C}\right)$ as ${ }^{\circ} \mathrm{C}=\left({ }^{\circ} \mathrm{F}-32\right) / 1.8$.

\section{Datum}

Horizontal coordinate information is referenced to the North American Datum of 1983 (NAD 83). 


\section{Abbreviations}

$\begin{array}{ll}\Phi & \text { phi } \\ \text { AWC } & \text { available water capacity } \\ \text { FA056 } & \begin{array}{l}\text { Food and Agriculture Organization of the United Nations Drainage and } \\ \text { Irrigation Paper } 56\end{array} \\ \text { gSSURG0 } & \text { gridded Soil Survey Geographic Database } \\ \text { K } & \text { plant growth coefficient } \\ \text { MAE } & \text { mean absolute error } \\ \text { MELCD } & \text { Maine Land Cover Dataset } \\ \text { netCDF } & \text { Network Common Data Format } \\ \text { NRCS } & \text { Natural Resources Conservation Service } \\ p \text {-value } & \text { probability } \\ \text { PEST } & \text { Parameter ESTimation } \\ \text { PPCC } & \text { probability plot correlation coefficient } \\ r & \text { correlation coefficient } \\ \text { RMSE } & \text { root mean square error } \\ \text { SSEBop } & \text { operational Simplified Surface Energy Balance } \\ \text { SVD } & \text { singular value decomposition } \\ \text { SWB } & \text { Soil-Water-Balance } \\ \text { USDA } & \text { U.S. Department of Agriculture } \\ \text { USGS } & \text { U.S. Geological Survey } \\ & \end{array}$





\title{
Groundwater Recharge Estimates for Maine Using a Soil-Water-Balance Model-25-Year Average, Range, and Uncertainty, 1991 to 2015
}

\author{
By Martha G. Nielsen and Stephen M. Westenbroek
}

\section{Abstract}

To address the lack of information on the spatial and temporal variability of recharge to groundwater systems in Maine, a study was initiated in cooperation with the Maine Geological Survey to use the U.S. Geological Survey Soil-WaterBalance model to evaluate annual average potential recharge across the State over a 25-year period from 1991 to 2015. The Maine Soil-Water-Balance model was calibrated using annual observations of recharge, runoff, and evapotranspiration for 32 calibration watersheds in the State during 2001-12 (902 total observations). Observations of recharge, runoff, and evapotranspiration were developed for each watershed to reduce the possibility of nonunique combinations of model parameters during the calibration. The Maine Soil-WaterBalance model was run using an optional evapotranspiration calculation method that provides more control for calibration than the standard method. The model was calibrated using the Parameter ESTimation software suite.

The overall mean model error (average of all annual residuals for recharge, runoff, and precipitation) was 0.39 inches. The mean of the absolute value of the residuals, or the mean absolute error, was 2.32 inches. The root mean squared error for the calibrated model overall was 3.14 inches. Statistical tests indicated that the model residuals are normally distributed. To determine the potential uncertainty in the median annual potential recharge that results from uncertainty in the parameters as they relate to information contained in the observations, 300 alternate model realizations were run, and the standard deviation of the median potential recharge value at every pixel was calculated.

Simulated 25-year median potential recharge across the State is widely variable; this variability closely follows patterns of precipitation, with additional variability contributed by the patchwork nature of the combinations of land-use class and hydrologic soil group inputs, and distribution of available water capacity in the soil across the State. Overall, the 25-year median annual potential recharge across the State is 7.5 inches, ranging from a low of about 5 inches to over 30 inches. The statewide range in the 25 -year minimum values is from just over 2 inches to just over 20 inches. The statewide range in the 25-year maximum potential recharge is between 15 and 48 inches per year.

The model areas with the highest simulated median potential recharge include areas underlain by type A soils (sandy and well drained), particularly those that also have land uses with low or little vegetation (blueberry barrens, developed, open space, scrub/shrub, and cropland, for example). The potential recharge values for these areas are similar to previously published values for comparable soil types.

The 25-year average potential recharge grids were compared to recharge evaluated through groundwater-flow models or other methods in four hydrogeologic settings at six study areas in the State. A key factor in the ability of the Soil-Water-Balance model to reproduce the earlier study results was whether the available water-capacity data were an appropriate match for the hydrologic soil groups. The Maine Soil-Water-Balance model does a good job in representing an accurate potential recharge under circumstances where the surficial mapped soils extend below the surface to the watertable aquifer and where the available water-capacity data are in an appropriate range for the hydrologic soil group. One hydrogeologic setting that was challenging for the model was where a silt and clay layer was below a shallow soil unit that did not have available water-capacity data that were appropriate for the hydrologic soil group. In these cases, typically the available water-capacity data were very low, not accounting for the impedance of water flow provided by the underlying soil. The model also does not simulate well areas where bedrock surfaces are above the water table but below the plant rooting zone.

The data products accompanying this report are intended to be used to provide first-cut estimates of recharge for geographic areas no smaller than the smallest watersheds used in the calibration of the model-or about 1.5 square miles. It is recommended that the grids are used to calculate an area-wide average potential recharge for any given area of study, and an uncertainty around the mean should be calculated from the standard deviation grid at the same time. 


\section{Introduction}

A small amount of groundwater recharge (or potential recharge) information exists for the State of Maine. Groundwater recharge is one of the most difficult components of the water cycle to determine, yet it is important for determining water availability for almost any purpose (for example, irrigation or drinking-water withdrawals, and in-stream flows for aquatic resources). Few site-specific recharge estimates in the State, either from calibrated groundwater-flow models or other analytical studies, have been published, and all the estimates published to date cover small geographic areas. Most groundwater used in Maine falls under three general categories: domestic private-well usage, crop irrigation, and public-water supply. Groundwater availability varies greatly across the State: productive sand and gravel aquifers (many of which are narrow valley-fill aquifers) are spatially discontinuous and cover a relatively small percentage of the landscape, and less productive glacial till and bedrock areas cover most of the State.

The largest limiting factors to sustainable groundwater use are the ability of an aquifer to store and transmit water and the amount of recharge to aquifers. Recharge is also highly variable - published values range from 2 to over 27 inches per year (in/yr) — and the physical characteristics of the soil and material above the underlying aquifers contribute greatly to the amount of recharge in any given location. Recharge also varies year-by-year depending on climate conditions, such as temperature and the amount and timing of rainfall and snowmelt.

To increase the ability of managers to understand the spatial and temporal variability of recharge to groundwater systems across the State of Maine and to analyze water budgets across the landscape, a study was initiated by the U.S. Geological Survey (USGS), in cooperation with the Maine Geological Survey to use the USGS Soil-WaterBalance (SWB) model to evaluate annual average potential recharge across the State. This study constructed and calibrated an SWB model of annual potential recharge over a 25-year period (1991 to 2015). Results are presented as 25-year annual average potential recharge (mean and median), the range of annual potential recharge (minimum and maximum) over the same time period, and the standard deviation of the mean 25-year average potential recharge, which was calculated using Monte Carlo methods (for a description of this method applied in groundwater modeling, see Anderson and others, 2015, p. 471).

\section{Purpose and Scope}

The purpose of this report is to document the construction and calibration of the SWB model for the State of Maine, and to describe the average (mean and median), minimum, and maximum annual potential recharge for the State from 1991 to 2015 and the uncertainty of those calculations. The SWB model archive is available in an accompanying data release (Nielsen, 2019). This study provides a baseline of information on potential recharge rates for the State of Maine. The methods and a summary of the project results are presented in this report; detailed data in the form of geospatial layers of average annual, minimum, and maximum potential recharge and model uncertainty are made available in an accompanying data release (Nielsen and Westenbroek, 2019).

\section{Previous Studies}

Few data are available from published studies on groundwater recharge rates in Maine. Although consultants and State agencies have constructed numerous small groundwater-flow models for the analysis of groundwater availability for public drinking-water supplies and for the delineation of wellhead protection zones, the recharge rates used in those models are not available publicly and have not been published. A compilation of recharge rates for many typical soil types across the State was published in 1996 by the Geological Society of Maine (Gerber and Hebson, 1996) using results from several calibrated groundwater models conducted by consulting companies in the early 1990s, but that was the last published summary of available data and included relatively few studies primarily in southern Maine. Recharge rates for glaciomarine silt/clay soils ranged from 2 to $12 \mathrm{in} / \mathrm{yr}$, rates for sandy glacial outwash were reported as high as $27 \mathrm{in} / \mathrm{yr}$, and recharge to bedrock units ranged from 2 to $6 \mathrm{in} / \mathrm{yr}$. The USGS has published a limited number of groundwater studies with recharge analyses (Morrissey, 1983; Tepper and others, 1990; Nielsen, 2002; Nielsen and Locke, 2012, 2015), but these are limited in geographic coverage and report recharge values within the same range as earlier studies. To date (2019), there have not been any previous attempts at providing even a general statewide average of recharge rates for various aquifers, soil types, or both across the whole State.

\section{Use of the Soil-Water-Balance Model for Regional-Scale Recharge Estimation}

In recent years, the USGS has made frequent use of a computer code called the Soil-Water-Balance (SWB) Model (Westenbroek and others, 2010, 2018) to generate spatial datasets of potential recharge for large geographic areas such as the State of Minnesota (Smith and Westenbroek, 2015) and the glaciated terrain across the northern United States (Trost and others, 2018). The SWB method of recharge estimation calculates potential recharge to groundwater using inputs of precipitation, temperature, land cover, and soil information, and estimates of potential and actual evapotranspiration (ET). The calculations done using this method traditionally have been used in the agricultural sector to estimate crop water demands, but they also can be used to provide estimates of excess soil moisture, which is the source of recharge to groundwater (Westenbroek and others, 2010). Using 
independent data on recharge for a particular study area, others have calibrated the SWB output for long-term (annual to multiyear average annual) recharge in Minnesota (Smith and Westenbroek, 2015), Rhode Island (Friesz and Stone, 2014), the Lake Michigan Basin (Feinstein and others, 2010), the North Atlantic Coastal Plain (Masterson and others, 2013), the Appalachian Plateau (McCoy and others, 2015), and the USGS glacial aquifers study area (Trost and others, 2018). Long-term base flow from unregulated USGS streamgages has been used by many of these studies to represent spatially averaged watershed recharge as a calibration target dataset for SWB models. A thorough summary of the use of base-flowderived recharge estimated by various methods of hydrograph separation used as a calibration target dataset for large SWB models is given in Trost and others (2018). For the Maine SWB model, streamflow data from 32 unregulated watersheds were used for the recharge and runoff calibration targets (fig. 1; table 1).

Although the SWB software simulates other components of the overall water budget, including direct runoff and actual ET, few SWB model calibrations to date have used more than observed recharge values to calibrate the model. The SWB model software includes many potential adjustments that control ET and runoff, and the values chosen for these parameters cascade through the calculations to impact potential recharge as well. None of the previous examples of calibrated SWB recharge models reviewed for this study constrained the calibration using ET data, which could result in a nonunique and possibly inappropriate fit of the model parameters. The Maine SWB recharge model presented in this report was calibrated using all available water-balance terms (recharge, direct runoff, and ET), which should result in a more robust and better constrained model. Furthermore, none of the SWB model studies published to date have attempted to quantify the uncertainty in the results, possibly because of the long run times for a large SWB model; this study conducted a robust calculation of the uncertainty in the modeled potential recharge across the State of Maine.

\section{Description of Study Area}

The Maine SWB recharge model was applied to the nearsurface soils and shallow aquifers across the State of Maine, where soil data to run the model were available. The model was run for all soil types in the State, regardless of whether they constituted a significant water-bearing unit or not. The surficial soils in Maine are all derived from the action of glaciers on the landscape, either as depositional units directly from the melting of the glaciers, or a later reworking of the glacial deposits. Some areas are now devoid of what would be a typical soil because the advance and retreat of glaciers and subsequent erosion has exposed the underlying bedrock at the land surface. These, too, are mapped and classified within the study classification scheme, and model output is reported.

A few areas of the State were excluded from the model because soil data have not been mapped and published in these areas. The White Mountain National Forest in western Maine does not have published soil data, nor does the former Brunswick Naval Air Station in the southern part of the State. The soil information necessary to run the SWB model is lacking over surface-water bodies as well. No calculations were done in any of these areas. 


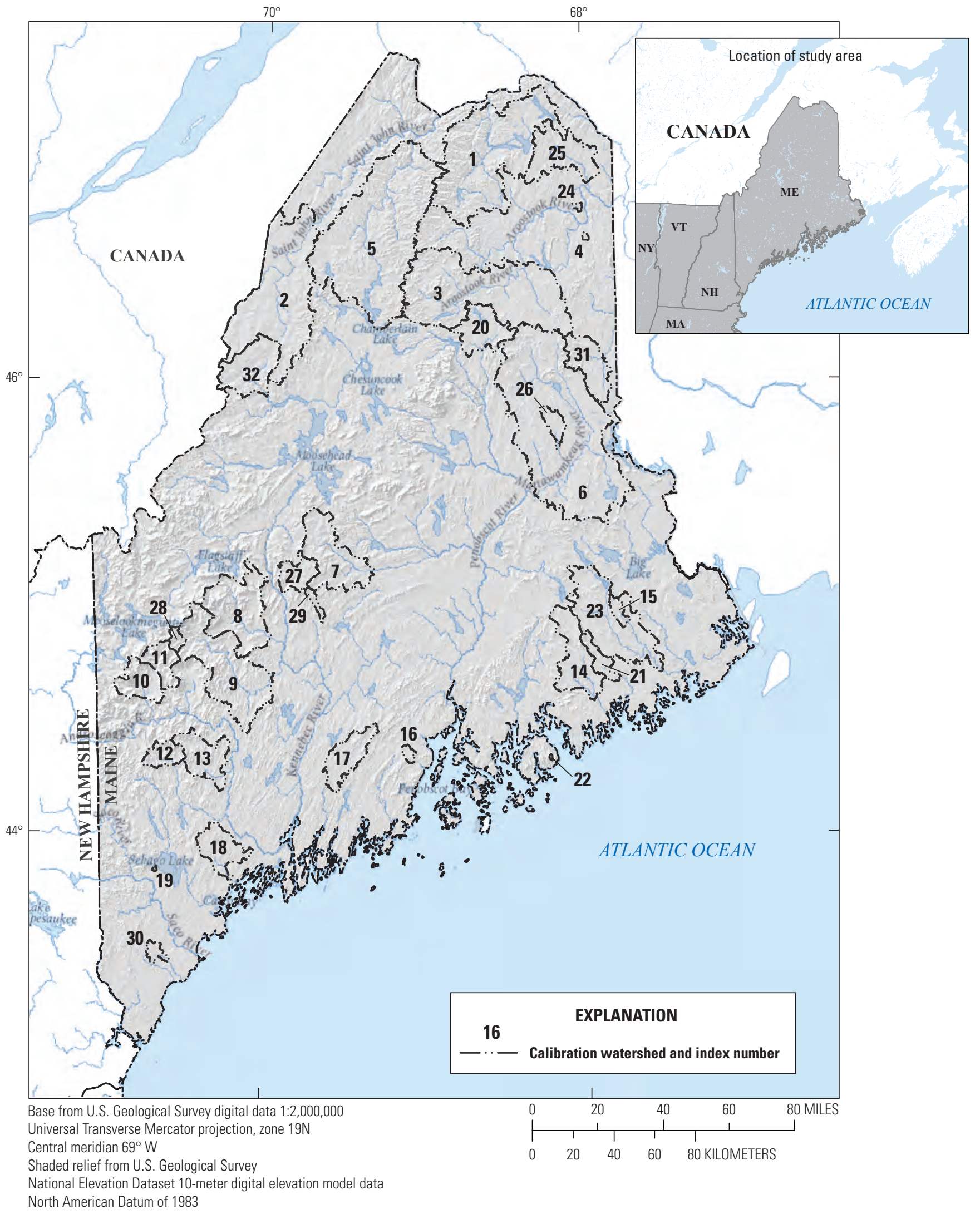

Figure 1. Calibration watersheds used in the Maine Soil-Water-Balance model and location of the study area. 
Table 1. Calibration watersheds used in the Maine Soil-Water-Balance model and associated streamgage information.

$\left[\mathrm{mi}^{2}\right.$, square mile]

\begin{tabular}{|c|c|c|c|}
\hline $\begin{array}{l}\text { Calibration } \\
\text { watershed } \\
\text { index number } \\
\text { (fig. 1) }\end{array}$ & Watershed observation name & $\begin{array}{c}\text { Watershed } \\
\text { area } \\
\left(\mathrm{mi}^{2}\right)\end{array}$ & $\begin{array}{l}\text { Streamgage station name } \\
\text { (with station number) }\end{array}$ \\
\hline 1 & Fish River & 867.1 & Fish River near Fort Kent, Maine (01013500) \\
\hline 2 & St. John River & $1,339.0$ & St. John River at Ninemile Bridge, Maine (01010000) \\
\hline 3 & Aroostook River & 895.1 & Aroostook River near Masardis, Maine (01015800) \\
\hline 4 & Williams Brook & 3.9 & Williams Brook at Phair, Maine (01017550) \\
\hline 5 & Allagash River & $1,229.6$ & Allagash River near Allagash, Maine (01011000) \\
\hline 6 & Mattawamkeag River & $1,420.3$ & Mattawamkeag River near Mattawamkeag, Maine (01030500) \\
\hline 7 & Piscataquis River & 297.3 & Piscataquis River near Dover-Foxcroft, Maine (01031500) \\
\hline 8 & Carrabassett River & 352.7 & Carrabassett River near North Anson, Maine (01047000) \\
\hline 9 & Sandy River-Mercer & 516.1 & Sandy River near Mercer, Maine (01048000) \\
\hline 10 & Ellis River & 130.4 & Ellis River at South Andover, Maine (01054300) \\
\hline 11 & Swift River & 96.8 & Swift River near Roxbury, Maine (01055000) \\
\hline 12 & Little Androscoggin River & 73.9 & Little Androscoggin River near South Paris, Maine (01057000) \\
\hline 13 & Nezinscot River & 168.5 & Nezinscot River at Turner Center, Maine (01055500) \\
\hline 14 & Narraguagus River & 227.0 & Narraguagus River at Cherryfield, Maine (01022500) \\
\hline 15 & Old Stream & 29.8 & Old Stream near Wesley, Maine (01021480) \\
\hline 16 & Ducktrap River & 15.0 & Ducktrap River near Lincolnville, Maine (01037380) \\
\hline 17 & Sheepscot River & 144.9 & Sheepscot River at North Whitefield, Maine (01038000) \\
\hline 18 & Royal River & 141.0 & Royal River at Yarmouth, Maine (01060000) \\
\hline 19 & Stony Brook & 1.6 & Stony Brook at East Sebago, Maine (01063310) \\
\hline 20 & Seboeis River & 172.7 & Seboeis River near Shin Pond, Maine (01029200) \\
\hline 21 & Pleasant River & 61.1 & Pleasant River near Epping, Maine (01022260) \\
\hline 22 & Otter Creek & 1.3 & Otter Creek near Bar Harbor, Maine (01022840) \\
\hline 23 & Machias River & 457.7 & Machias River at Whitneyville, Maine (01021500) \\
\hline 24 & Hardwood Brook & 5.7 & $\begin{array}{l}\text { Hardwood Brook below Glidden Brook near Caribou, Maine } \\
\quad(01017060)\end{array}$ \\
\hline 25 & Little Madawaska River & 234.1 & Little Madawaska River at Caribou, Maine (01017290) \\
\hline 26 & Wytopitlock Stream & 48.6 & Wytopitlock Stream near Wytopitlock Maine (01030350) \\
\hline 27 & Austin Stream & 90.6 & Austin Stream at Bingham, Maine (01046000) \\
\hline 28 & Sandy River-Madrid & 25.3 & Sandy River near Madrid, Maine (01047200) \\
\hline 29 & East Branch Wesserunsett Stream & 19.4 & East Branch Wesserunsett Stream near Athens, Maine (01048220) \\
\hline 30 & Kennebunk River & 26.4 & Kennebunk River near Kennebunk, Maine (01067950) \\
\hline 31 & Meduxnekeag River & 170.6 & Meduxnekeag River near Houlton, Maine (01018000) \\
\hline 32 & North Branch Penobscot River & 223.5 & North Branch Penobscot River near Pittston Farm, Maine (01027200) \\
\hline
\end{tabular}




\section{Soil-Water-Balance Modeling Approach}

The SWB model was chosen for this study because it uses readily available datasets that cover the entire State. The model can thus estimate an average annual potential recharge rate for areas in the State that are relatively inaccessible and have not before had any hydrogeologic investigations to evaluate recharge. The final dataset produced by the model is not uniformly precise, however, and the use of automatic model calibration using parameter estimation allows for evaluating the uncertainty contributed by variability in the match of the model output to a large set of calibration data (observations) and the uncertainty in model parameters in the final datasets.

\section{Model Theory}

The SWB model (Westenbroek and others, 2010) calculates potential recharge using a modified ThornthwaiteMather soil-water accounting method (Thornthwaite and Mather, 1957). Water-budget calculations are performed on each model cell for each day of the simulation, where recharge is the excess of the sources of water to each cell (precipitation and snowmelt) minus the sinks (interception, runoff, and ET), adjusted for changes in soil moisture (Westenbroek and others, 2010). Precipitation during the winter when the average daily temperature is below freezing is stored as snowpack, which the SWB model allows to melt during days when at least part of the day is above freezing. Direct runoff is controlled using the curve-number method (Cronshey and others, 1986), which accounts for soil types, land use, the soilsurface condition, and antecedent runoff conditions. Runoff curve numbers are set initially and allowed to vary during the simulation period in relation to the degree of soil saturation and whether the ground is frozen (Westenbroek and others, 2010). Water that could infiltrate the soil given the results of the curve-number method calculations but exceed the maximum infiltration capacity of the soil are represented as "rejected recharge" and are part of the overall runoff term. ET is calculated using one of several possible methods (see below in this section), and when potential ET is less than or equal to the amount of water available in the soil for use, actual ET equals potential ET. If the amount of water available is less than the potential ET, SWB calculates the amount of water that can be readily extracted for actual ET using ThornthwaiteMather retention curves (Westenbroek and others, 2010). SWB calculates a daily residual soil moisture surplus (potential recharge), the net change in soil moisture, and the daily ending soil moisture value, used to compute the water balance for the next day (fig. 2).

The SWB software uses two types of inputs: climate and physical data covering the simulation area; and tabular data (model parameters) that control the calculations of potential recharge, runoff, and ET. Gridded climate data were used as model inputs and include daily precipitation, and daily minimum and maximum temperature. The physical datasets for the model include a grid of available water-capacity (AWC) values and hydrologic soil groups (available from the Natural Resources Conservation Service [NRCS] soils data; Soil Survey Staff, 2016) and land-use classes, which are available from a variety of sources.

The SWB software (Westenbroek and others, 2010, version 1.2) provides two basic options for calculating ET: the Thornthwaite-Mather approach (Thornthwaite and Mather, 1957) or the Food and Agriculture Organization of the United Nations Drainage and Irrigation Paper 56 (FAO56) approach (Allen and others, 1998). According to the SWB user manual, "Thornthwaite and Mather's work was motivated by a need to estimate the surplus and deficit of soil water for irrigation needs, and may not necessarily represent ideal values for the purposes of groundwater-recharge estimation" (Westenbroek and others, 2010, p. 16). The FAO56 approach (Allen and others, 1998) also is widely applied for agricultural purposes but provides more explicit calculations of ET based on plantgrowth water demand and ET from the soil surface between plants. The plant-growth water demand calculations are based on plant-growth coefficients $\left(\mathrm{K}_{\mathrm{cb}}\right.$ values) that compare the ability of a type of vegetation to transpire water from the root zone compared to a reference crop (well-watered grass) during different phases of the growing season. Settings that control the soil surface ET (bare soil readily evaporable water and total evaporable water) can be adjusted to simulate soil covered with a layer of leaf litter, as is typically found in forested areas of New England. The implementation of the FAO56 calculations in SWB version 1.2 (and SWB version 2.0) are discussed in Westenbroek and others (2018).

The general approach to performing the model calculations is illustrated in figure 2, showing the overall inputs, use of datasets and variable parameters, and model outputs for each day. The cycle starts with a daily precipitation amount, daily minimum and maximum temperatures, and any residual soil moisture and snowpack; the various components of the water budget are calculated in steps. The amount available for net infiltration (potential recharge) is the second-to-last water-budget component that is calculated for each day. The final daily calculation is the residual soil moisture and residual snowpack (in cold months), which is then carried over as input to the next day's calculations. All of these calculations are performed on each gridded cell of the model.

\section{Model Area}

The model area for this study encompasses land areas within the State of Maine. The active model domain excludes areas where soils data are not available, including surfacewater bodies, the White Mountain National Forest, and former Brunswick Naval Air Station (for which soil data are not published). 


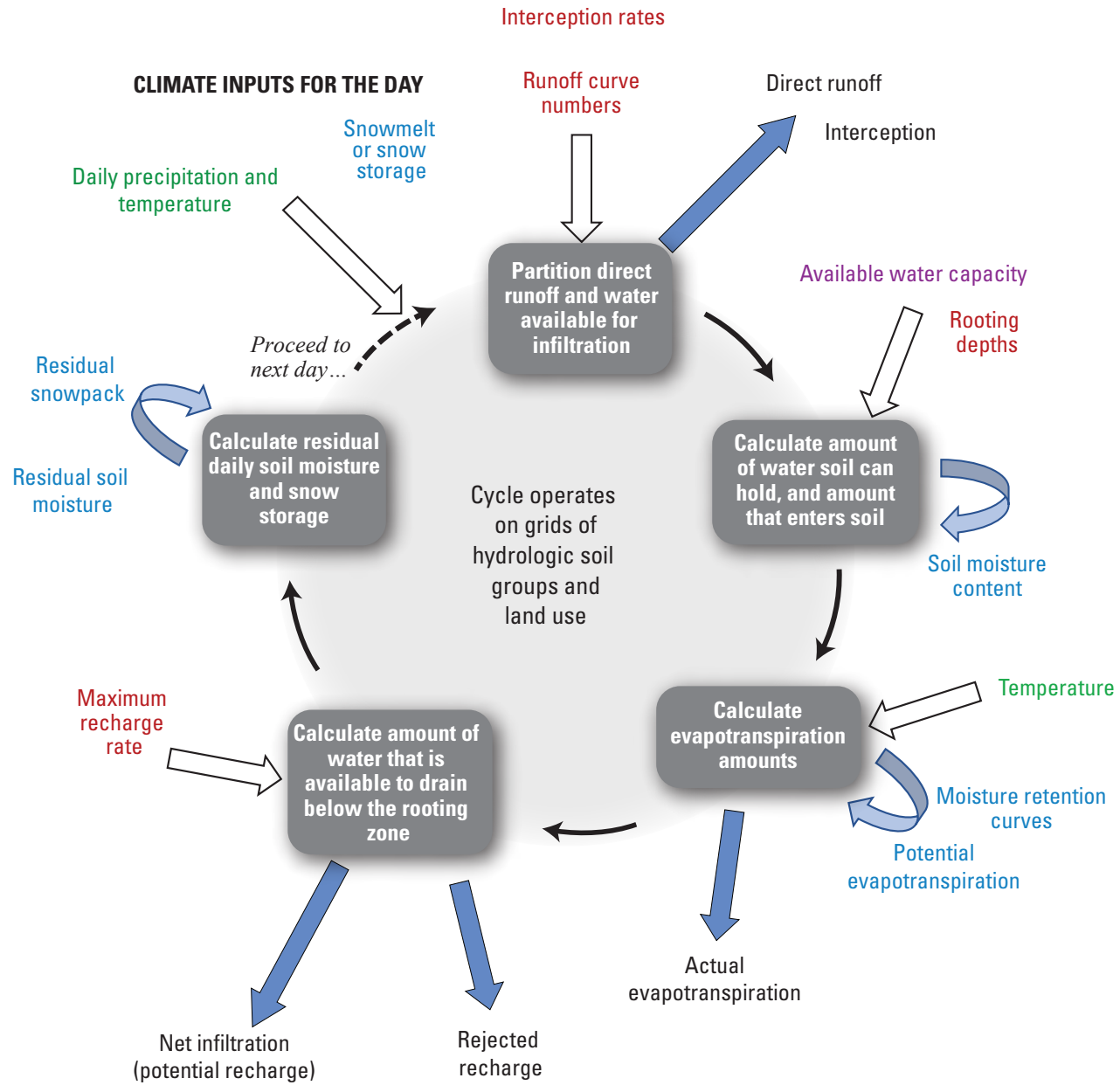

EXPLANATION

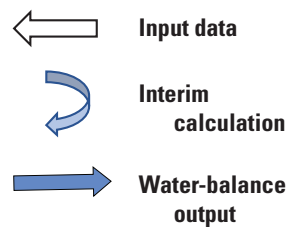

Data types

Daily climate inputs

Gridded datasets

Interim calculations

Lookup table values for land use-soil group

Water-balance component

Figure 2. Operation of daily Soil-Water-Balance calculations and water-balance output.

\section{Model Limitations and Assumptions}

The SWB model provides a useful method to calculate spatially varying potential recharge to groundwater on monthly to yearly time periods. However, there are some limitations to the model and assumptions that the user must consider. Westenbroek and others (2010) and Trost and others (2018) discuss the limitations and assumptions of the SWB method in detail. An abbreviated discussion of the most important considerations is presented below:

1. The SWB model calculates potential recharge as infiltration below the root zone. The results are not a substitution for recharge determined by detailed site-specific studies, such as a groundwater-flow model, where the timing and exact magnitude of groundwater recharge are needed to answer water-resource management questions.

2. The validity of the results requires that the input data (hydrologic soil groups, AWC, and land use) are known. Uncertainty from inaccurate soil data cannot be quantified in the analysis of uncertainty in the model calibration. In some areas of Maine, the soils data are the result of interpolation between soil units that are mapped based on aerial photography, and in some remote areas the soils data are not highly accurate (L. Hodgeman, NRCS, oral commun., 2015). The model does not calculate recharge over open surface-water bodies.

3. The SWB model does not account for lag times in the movement of water infiltrated below the rooting zone to the actual water table. Therefore, model results should not be used for periods of less than 1 year, and yearly estimates of potential recharge should only be presented as approximate and should most appropriately be used to represent ranges of potential recharge (Hunt and others, 2008; Trost and others, 2018).

4. The SWB model does not track the depth to water table in the simulations and does not represent conditions of very shallow water tables explicitly. Areas with abundant wetlands may not be simulated well, and some major processes of groundwater-surface water interaction in these areas are not accounted for (Westenbroek and others, 2010; Trost and others, 2018). 
5. The curve-number method has limitations in its ability to track water flow, and is best applied at the watershed scale, so the SWB output is best applied at scales of watersheds and not individual land parcels. It has also been suggested that curve numbers themselves vary by precipitation events and that the methods to account for this in the SWB model only capture some of this variability (Westenbroek and others, 2010).

6. Interception in the SWB model is accounted for in a "bucket" approach, where the volume is taken out of the direct precipitation available for infiltration. But the interception volume, which subsequently evaporates after the event is done, is not used in the ET calculations in SWB version 1.2. Using high interception numbers in the SWB model may result in the ET of interception water being counted twice in the model. Interception was turned off in the Maine SWB model to correct for this artifact.

\section{Model Calibration Approach}

Automated parameter estimation was used to calibrate the Maine SWB model, using the Parameter ESTimation (PEST) software (Doherty and Hunt, 2010). The method of calculating excess soil moisture (potential groundwater recharge) in the SWB model uses many adjustable parameters contained in the lookup tables (appendix tables 1.2 and 1.3, available for download at https://doi.org/10.3133/sir20195125). The values in the lookup tables together control how SWB divides up input to the hydrologic system into daily fractions of direct runoff, plant interception, soil infiltration, ET, soil moisture storage, rejected recharge, and infiltration of excess soil moisture to the water table (potential recharge), which are summed over a monthly or annual timestep. Some of these parameters have nonunique combinations that can produce the same amount of potential recharge for a given period. For example, an increase in the runoff curve number will generally increase direct runoff and make less water available for recharge. But decreasing the plant rooting depth can offset this by also reducing the amount of water available for transpiration after water has entered the rooting zone. Decreasing the runoff curve number to decrease runoff can be offset by an increase in the plant rooting depth, resulting in the same net recharge.

At the end of a timestep (monthly or annual), all the SWB output can be put into the general water-budget categories of runoff, infiltration of water beneath the root zone (potential recharge), actual ET, and storage of water in the soil or snowpack. For the Maine SWB model, an annual timestep was chosen to sum the SWB outputs.

To reduce the nonuniqueness of the calibration, three types of calibration targets were used: runoff, potential recharge, and ET. Runoff and potential recharge were derived from hydrograph separation, and ET was derived from satellite data. Direct runoff, as a component of hydrograph-separation calculations, is analogous to the sum of the SWB calculations of "runoff outside" (direct runoff during a precipitation event, or Hortonian overland flow; Chow and others, 1988) and "rejected recharge" (water that initially infiltrates the soil zone during a precipitation event but cannot infiltrate through the soil zone because of limitations in the maximum infiltration capacity of the soil, or saturation overland flow; Chow and others, 1988). Base flow is often assumed to represent long-term discharge from groundwater, which should equal groundwater recharge if ET from the water table is negligible and the groundwater and surface-water watersheds are coincident (Healy, 2010).

The calibration was conducted in stages, first by using a subarea of the model for an initial calibration (using 4 watersheds) and then finalizing the calibration with the whole State and 32 calibration watersheds (table 2). Because of the numerical burden of the number and speed of SWB runs needed for the calibration, the calibration was done using a 500-m grid-cell size, which runs four times faster than the final model spatial discretization of 250-m grid-cell size. Details of the calibration data, procedure, and results are presented below.

Table 2. Land-use classes for the Maine Soil-Water-Balance model.

\begin{tabular}{|c|c|c|}
\hline $\begin{array}{l}\text { Land-use } \\
\text { code }\end{array}$ & $\begin{array}{l}\text { Land-use class } \\
\text { (fig. 3) }\end{array}$ & Percentage \\
\hline 2 & $\begin{array}{l}\text { Developed- } \\
\text { High intensity }\end{array}$ & 0.3 \\
\hline 3 & $\begin{array}{l}\text { Developed- } \\
\text { Moderate }\end{array}$ & 0.3 \\
\hline 4 & $\begin{array}{l}\text { Developed- } \\
\text { Low intensity }\end{array}$ & 0.5 \\
\hline 5 & $\begin{array}{l}\text { Developed- } \\
\text { Open space }\end{array}$ & 0.5 \\
\hline 6 & Cultivated crops & 2.4 \\
\hline 7 & Pasture/hay & 2.1 \\
\hline 8 & Grassland & 0.2 \\
\hline 9 & Deciduous forest & 15.1 \\
\hline 10 & Evergreen forest & 20.3 \\
\hline 11 & Mixed forest & 35.2 \\
\hline 12 & Scrub/shrub & 10.3 \\
\hline 13 & Wetland forest & 3.7 \\
\hline 14 & $\begin{array}{l}\text { Wetlands from } \\
\text { soils }\end{array}$ & 4.2 \\
\hline 15 & Wetlands & 1.3 \\
\hline 16 & $\begin{array}{l}\text { Roads/runways/ } \\
\text { bare rock }\end{array}$ & 1.4 \\
\hline 20 & Bare land & 0.1 \\
\hline 21 & Open water & 1.6 \\
\hline 22 & $\begin{array}{l}\text { Blueberry } \\
\text { barrens }\end{array}$ & 0.3 \\
\hline 27 & Alpine/tundra & $<0.1$ \\
\hline 30 & Gravel pits & 0.1 \\
\hline
\end{tabular}




\section{Processing of Calibrated Model Output}

After the Maine SWB model calibration was completed, the model was run for a 26-year simulation period (1990-2015) using the final best-fit values for both lookup tables used in the simulation (appendix tables 1.2 and 1.3). Running the model for 26 years allows for a spin-up year that sets up the soil moisture and snow storage properly for the first year of the desired simulation (1991). The initial year of the run (1990) was not used in any of the subsequent processing steps. The final model runs used a finer model grid-cell size $(250 \mathrm{~m})$ than the calibration runs $(500 \mathrm{~m})$.

The 25 annual recharge grids were run through several postprocessing steps to obtain the final model results. The first step was to do statistical analysis on the 25 annual grids - calculating the 25 -year minimum, mean, median, and maximum values for each pixel in the model domain. This was done using the ArcGIS version 10.6 software. Further postprocessing of the calculated grids included removing data from an exclusion zone in northwestern Maine (see the "Groundwater Recharge Estimates for Maine, 1991-2015" section, below) and screening out anomalously high values, which can arise from slightly misaligned original input grids. The top 0.25 percent of calculated values were reassigned to the 99.75-percentile value. In the following discussion, the 99.75-percentile value is termed the "maximum" for each grid. A final postprocessing step was to apply a low-pass filter ( 3 by 3 cells), which smoothed out the impact of single pixels that had values that were very dissimilar to their local neighborhood of values, which generally was a result of slightly misaligned input grids. The low-pass filter also smoothed out abrupt boundaries between zones of very different simulated potential recharge. Although a slight loss of information results from the smoothing process, the resulting grids better reflect the scale of landscape variability in the State and reduce the potential for misuse of the potential grids that could arise from assuming pixel-scale variability is reflective of actual conditions. Further discussion of the model outputs refers to the grids with the low-pass filter applied, unless otherwise noted. These steps were carried out using a combination of ArcGIS data manipulation and python-based raster analysis.

\section{Model Uncertainty Representation}

One of the goals of this investigation was to be able to portray the uncertainty inherent in the estimated values of potential recharge. Current numerical methods for evaluating the uncertainty of a model calibrated using PEST (Doherty and Hunt, 2010) limit the analysis to uncertainty in the overall model results that arise from uncertainties in the values of the parameters that are used in the model. No measure currently (2017) exists for incorporating uncertainty from the model input data (such as the soil grids or climate data) into this analysis, unfortunately. Portraying the uncertainty in the results of the SWB modeling exercise is difficult because the study result is not a prediction of a change in some measurable volume or measurement of interest but rather a surface across the entire State. Techniques of uncertainty analyses using linear-based first-order, second-moment methods to analyze model response to specific conditions at a particular time and place (see White and others, 2016) are not readily applicable to this kind of output. No published SWB model has shown the spatial uncertainty in the modeled potential recharge to date (2019).

The null-space Monte Carlo method of Tonkin and Doherty (2009) was used to spatially represent the uncertainty in the potential recharge grids. Because of the complexity of the analysis, the uncertainty calculations were run using only one of the final grids: the median potential recharge grid. Because the mean potential recharge grid differs only a small percentage (about 2 percent) from the median grid, the uncertainty for the mean grid should not be substantially different from that for the median grid.

The Monte Carlo analysis was performed using many potential alternate realizations of the suite of model parameter values (Tonkin and Doherty, 2009) used in the calibration. The pyEUM software (White and others, 2016) was used to generate the 300 unique parameter sets needed to run the analysis. Each realization of the set of parameter values was generated by sampling a normal distribution of values around the calibration best-fit value for each modeled parameter (even if they were not specifically estimated using PEST), using an assumed possible range of values of plus or minus 3 sigma $(\sigma)$. The upper and lower bounds of the ranges for each parameter were first obtained from the PEST calibration upper and lower bounds, which were adjusted after the calibration for this purpose to create balanced upper and lower reasonable ranges of values around the calibration value. For computational efficiency, the Monte Carlo runs were done using the 500-m grid-cell size used in the calibration. Simultaneous model runs were controlled and organized using the HTCondor computer cluster at the T.C. Chamberlin computing center at the USGS Wisconsin office of the Upper Midwest Water Science Center.

\section{Maine Soil-Water-Balance Model Description and Calibration}

The SWB software (Westenbroek and others, 2010), version 1.2, was used for the simulation of recharge and other components of the water budget for Maine. The Maine SWB model used two scales of input and output data. The model was calibrated at a 500-m grid-cell size using 12 years of simulation to make the run times for the model reasonable enough to allow for thousands of model runs per calibration run. Once the lookup table values were calibrated, the model was run for the final time for a 25 -year period using a $250-\mathrm{m}$ grid-cell size. The model domain includes 678,384 500-m grid cells and 2.713 million 250-m grid cells. 


\section{Model Input Data Summary}

The input required for running the Maine SWB model consists of (a) grids describing the study domain (land use, hydrologic soil types, and soil AWC); (b) gridded daily climate data; (c) tabular values (parameters) that control the water balance calculations, including runoff curve numbers, maximum potential infiltration rates, rooting depths, and information on how interception is handled for each combination of land-use class and hydrologic soil type (these are sent to the SWB software in a tab-delimited text file called the land-use lookup table); and (d) another set of tabular values in a lookup table for implementing the FAO56 ET calculations, called the irrigation lookup table. Gridded data from all data sources except the climate data were resampled to the Maine SWB model scales of 250 and $500 \mathrm{~m}$ (see the "Gridded Model Data" section below).

\section{Gridded Model Data}

Land-use data for the Maine SWB model were based on the Maine Land Cover Dataset (MELCD; Maine Office of Geographic Information Systems, 2006; see appendix 1). The MELCD data are based on Landsat Thematic Mapper 5 and 7 imagery from 1999 and 2000 and have a spatial resolution of $5 \mathrm{~m}$. Land-use classes from the MELCD were condensed into 19 categories (table 2; fig. 3 ). Some modifications to water, wetland areas, and gravel pits were made using the NRCS soils data so that these areas did not conflict between the soil classes and land uses. The resampling to 250- and 500-m grid resolution was done by calculating the most prevalent land use in each larger grid cell. A test was done to determine whether resampling to coarser grid cells changed the overall distribution of land uses in the study area. When the 5-m MELCD data were resampled to 250 and $500 \mathrm{~m}$, the overall percentage of each land use was the same as the original, to within 0.2 percent.

The other two data inputs for SWB (hydrologic soil groups and AWC) were produced for this study using gridded soil survey data from 2016 (NRCS gridded Soil Survey Geographic Database [gSSURGO] data, Soil Survey Staff, 2016). The data format is a raster of soil map-unit keys with a 10-m resolution. The map-unit keys link the raster cells to many attribute tables, including (among others) hydrologic soil groups, drainage classes, soil-unit descriptions, parent material, and AWC. The gridded data were resampled to 250 and $500 \mathrm{~m}$ for the Maine SWB model.

The hydrologic soil groups (U.S. Department of Agriculture [USDA], NRCS, 2007) are used in SWB alongside land use to classify the landscape into combinations of land use/vegetation and soil texture that are assumed to transmit water similarly through the rooting zone and unsaturated zone to the water table under the same climatic conditions (Westenbroek and others, 2010). Previous studies using the NRCS hydrologic soil groups as the basis for the soil type data in SWB have generally used the standard seven hydrologic soil groups as defined by the NRCS (A, A/D, B, B/D, C, C/D, and $\mathrm{D}$ ), where the soils in groups $\mathrm{A}, \mathrm{B}, \mathrm{C}$, and $\mathrm{D}$ range from being able to transmit water very freely (group A soils) to soils that do not transmit water well at all, especially when saturated (group D soils). The groups A/D, B/D, and C/D refer to soils that transmit water differently when saturated and often apply to areas with shallow water tables (wetland areas; USDA, NRCS, 2007).

An initial evaluation of the use of SWB in Maine for this study determined that the group D soils include a range of soil types that ranges, on one end, from tight clay deposits on coastal lowlands, to areas that have thin (0-6 in.) soils over exposed bedrock in mountainous areas with high slopes. Because the process of generating runoff and recharge from incoming precipitation in these areas is quite different, the group D soils for Maine were subdivided into three subgroups based on the soil drainage class for each soil unit: "D-Ex" are the D soils that are also excessively drained (primarily shallow soils over bedrock, often steep slopes); "D-SoEx" (somewhat excessively drained D soils) are primarily soils in subdued hilly areas and often are composed of glacial till; "D-Poor" (poorly and somewhat poorly drained D soils) are a group of several poorly drained soil types, including glacial clay deposits, silt loam soils (farmable but not peats), silt-loams, and silty clay loams and silt loams (no plant material or peat mentioned). Some are tidal marshes or upland areas of poor drainage (forested). The nine hydrologic soil groups used in the Maine SWB model are listed in table 3, and their distribution is shown in figure 4.

The model calculates potential recharge based on each cell's individual land-use class and hydrologic soil group. Considering all the possible combinations of land-use class and hydrologic soil groups in the model area, there are 171 possible categories created by the intersection of these two datasets (table 4). Many of the categories have near zero area across the landscape. The 35 most-abundant categories (named using the format of "land-use class:hydrologic soil group") together represent 86 percent of the State (fig. 5). Maine is primarily a forested State-13 of the 15 most-abundant categories include mixed, evergreen, deciduous, or wetland forest land-use classes. The other two most abundant categories are scrub/shrub:D-Poor and scrub/shrub:C/D, which largely cover areas in northern and northwestern Maine that were recovering from heavy logging operations in the 1990s. The mixed forest:D-poor, evergreen forest:D-poor, mixed forest:C/D, mixed forest:C, mixed forest:D-SoEx combined account for 37.9 percent of the model area.

The AWC in the soil horizon is defined as the number of inches of water that can be held per foot of soil thickness (see the NRCS Soil Survey Manual [Ditzler and others, 2017] for a complete description of the derivation of these data). The AWC is used by SWB to calculate the maximum amount of soil-water storage that can be held in a model grid cell. SWB calculates the total amount of potential soil moisture storage as the AWC times the rooting zone depth for each model cell, where the rooting zone depths are adjusted for each land-use 


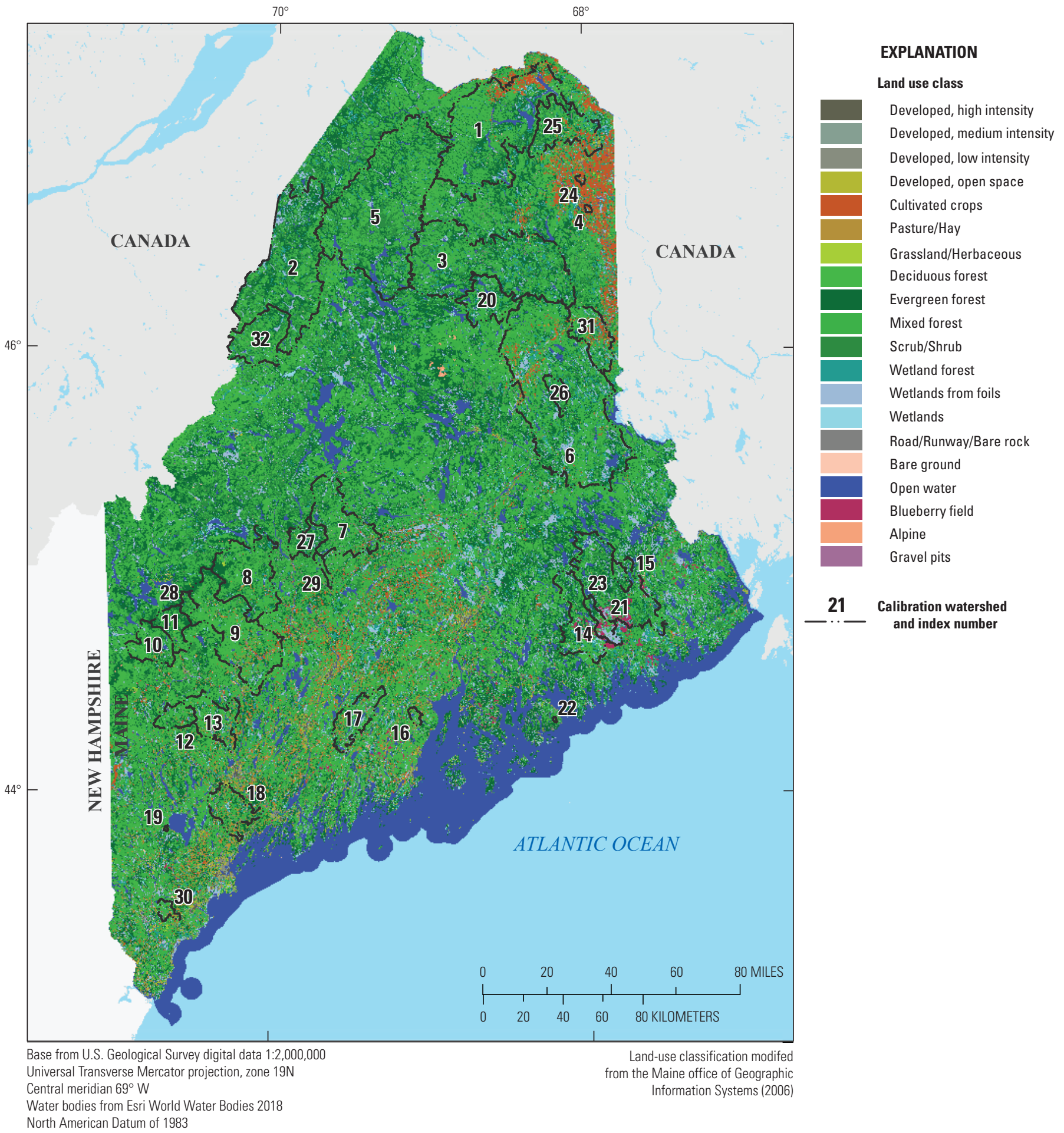

Figure 3. Land use for the Maine Soil-Water-Balance model and calibration watersheds. 
Table 3. Hydrologic soil groups used in the Maine Soil-Water-Balance model.

\begin{tabular}{|c|c|c|c|}
\hline $\begin{array}{l}\text { Soil group } \\
\text { number }\end{array}$ & $\begin{array}{l}\text { Hydrologic } \\
\text { soil group } \\
\text { (fig. 4) }\end{array}$ & Description & $\begin{array}{l}\text { Percentage of } \\
\text { model area }\end{array}$ \\
\hline 1 & A & Low runoff potential when wet; water is transmitted freely through the soil & 7.6 \\
\hline 2 & $\mathrm{~A} / \mathrm{D}$ & High water transmission rates; water table $<60$ centimeters from the surface (often wetlands) & 4.2 \\
\hline 3 & $\mathrm{~B}$ & Moderately low runoff potential when wet; water transmission is unimpeded & 4.3 \\
\hline 4 & $\mathrm{~B} / \mathrm{D}$ & Moderate water transmission rates; water table $<60$ centimeters from the surface (often wetlands) & 2.0 \\
\hline 6 & $\mathrm{C} / \mathrm{D}$ & $\begin{array}{l}\text { Moderately low water transmission rates; water table }<60 \text { centimeters from the surface (often wet- } \\
\text { lands) }\end{array}$ & 18.4 \\
\hline 7 & D-Ex & $\begin{array}{l}\text { High runoff potential; water movement is restricted; excessively drained (primarily thin soils over } \\
\text { shallow bedrock) }\end{array}$ & 2.0 \\
\hline 8 & D-SoEx & $\begin{array}{l}\text { High runoff potential when wet; water movement is restricted; somewhat excessively to moderately } \\
\text { drained }\end{array}$ & 12.6 \\
\hline
\end{tabular}

class:hydrologic soil group category using the SWB lookup table (see the "Lookup Tables and Control File" section below). The available water-capacity grid for Maine (fig. 6) was obtained from the gSSURGO data (Soil Survey Staff, 2016), and modified for areas of missing data (appendix 1).

Although the AWC of the soil, or the amount of water that a soil can hold under saturated conditions, could be thought of as a component of the soil's hydrologic description, there is not a strong relation between the hydrologic soil groups and the AWC for Maine soils, as illustrated in figure 7. The AWC for hydrologic soil groups A and D-Ex are distinctive in that there is a higher proportion of cells with less than 3 in. of storage per foot than in the other categories, which would be appropriate for very sandy soils (generally describing group A), or thin soil over bedrock (D-Ex). And the amount of water-holding capacity generally increases as the soil group's capacity to transmit water gets lower, which would be appropriate for finer-grained soils that can hold more water than coarse-grained sandy soils. However, the graphs (fig. 7) illustrate that sometimes the AWC for a soil group does not match the description well-for example, the A/D soil group generally represents wet areas that are poorly drained, and the lack of drainage could increase the amount of water that the soil will hold dramatically as compared to the same soil that has free drainage. The way that SWB calculates infiltration below the rooting depth in a case where the AWC is low does not consider the lack of drainage, however, and could result in more calculated recharge than would otherwise seem reasonable.

The DayMet (version 3) daily climate data from the Oak Ridge National Laboratory (Oak Ridge, Tennessee; Thornton and others, 2018) were the source of the daily minimum and maximum temperature and daily precipitation data used in the Maine SWB model. These data, which are available in the Network Common Data Form (netCDF) format, have a spatial resolution of 1 kilometer. The DayMet data are derived from an algorithm that models daily temperature and precipitation based on ground-surface observations, elevation, and incident solar radiation (Thornton and others, 2018).

Precipitation is a major driver of potential recharge. Typically, the annual precipitation for Maine falls between 40 and 50 in. (fig. 8), with higher amounts at higher elevations and in some of the coastal areas and lower amounts in the rain shadow behind the northern end of the Appalachian Mountains and in northern Maine.

Another source of modeled precipitation data for the Nation are the Parameter-elevation Regressions on Independent Slopes Model (PRISM) data from Oregon State University (PRISM Climate Group, Oregon State University, 2012): annual "normal" precipitation from 1981 to 2010 (fig. 9). These data are available as monthly and annual data, with a spatial resolution of $800 \mathrm{~m}$. These data do not have the spatial or temporal granularity of the DayMet data and cannot be used with the SWB model, but the overall spatial pattern of annual precipitation for Maine should be comparable for both datasets. A gross comparison of the DayMet annual average (fig. 8) and the PRISM data (fig. 9) indicates general agreement in the overall patterns and amounts of annual precipitation, except for the area along the northwestern border with Canada, generally in the area covered by calibration watersheds numbers 2 (St. John River) and 32 (North Branch Penobscot River; and part of 5 [Allagash River]), extending south along the border towards New Hampshire (see fig. 8). This discrepancy is assumed to be an artifact of the interpolation method used by DayMet and the available weather stations between Maine and adjacent areas 


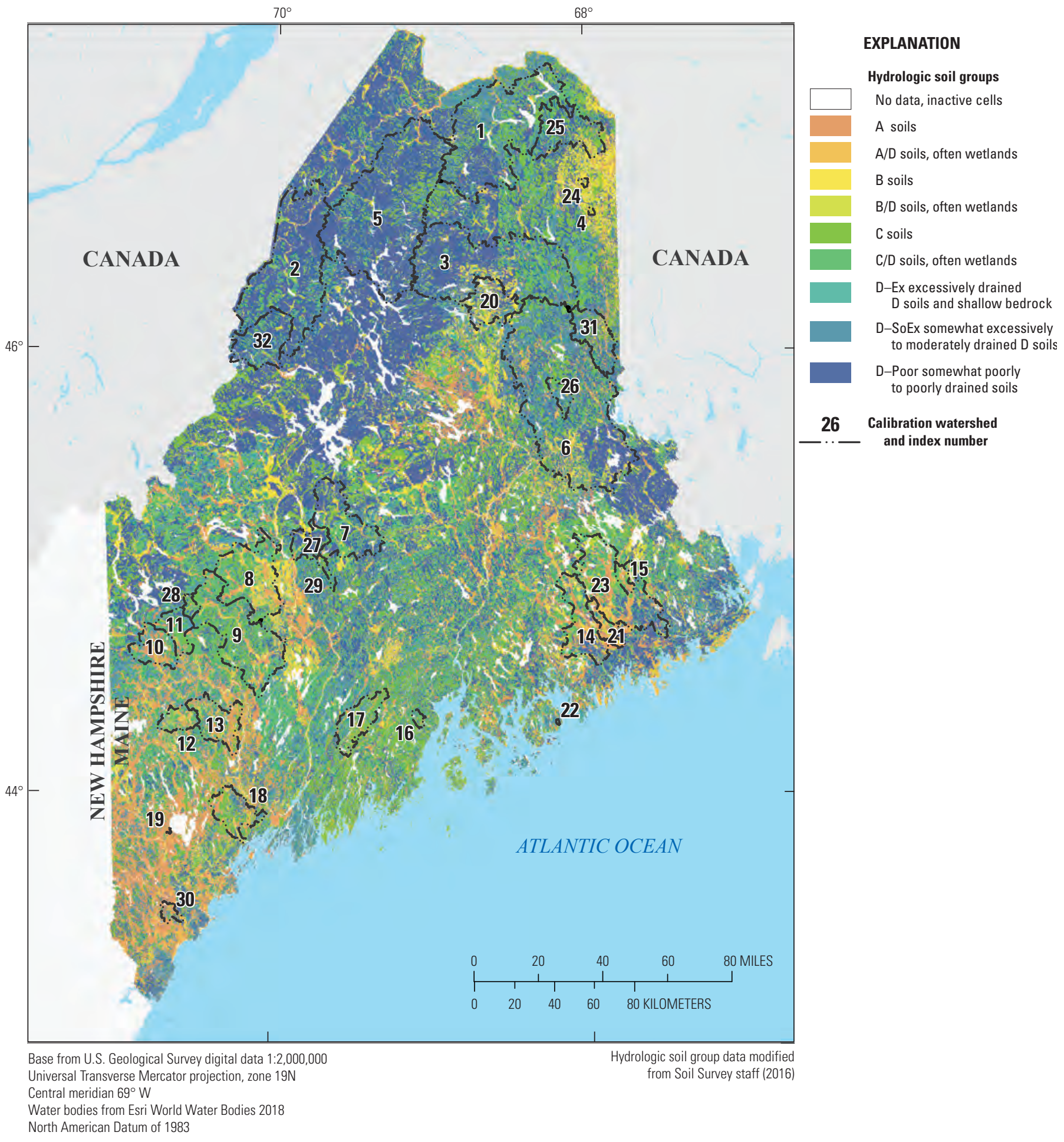

Figure 4. Hydrologic soil groups of the Maine Soil-Water-Balance model and calibration watersheds. 


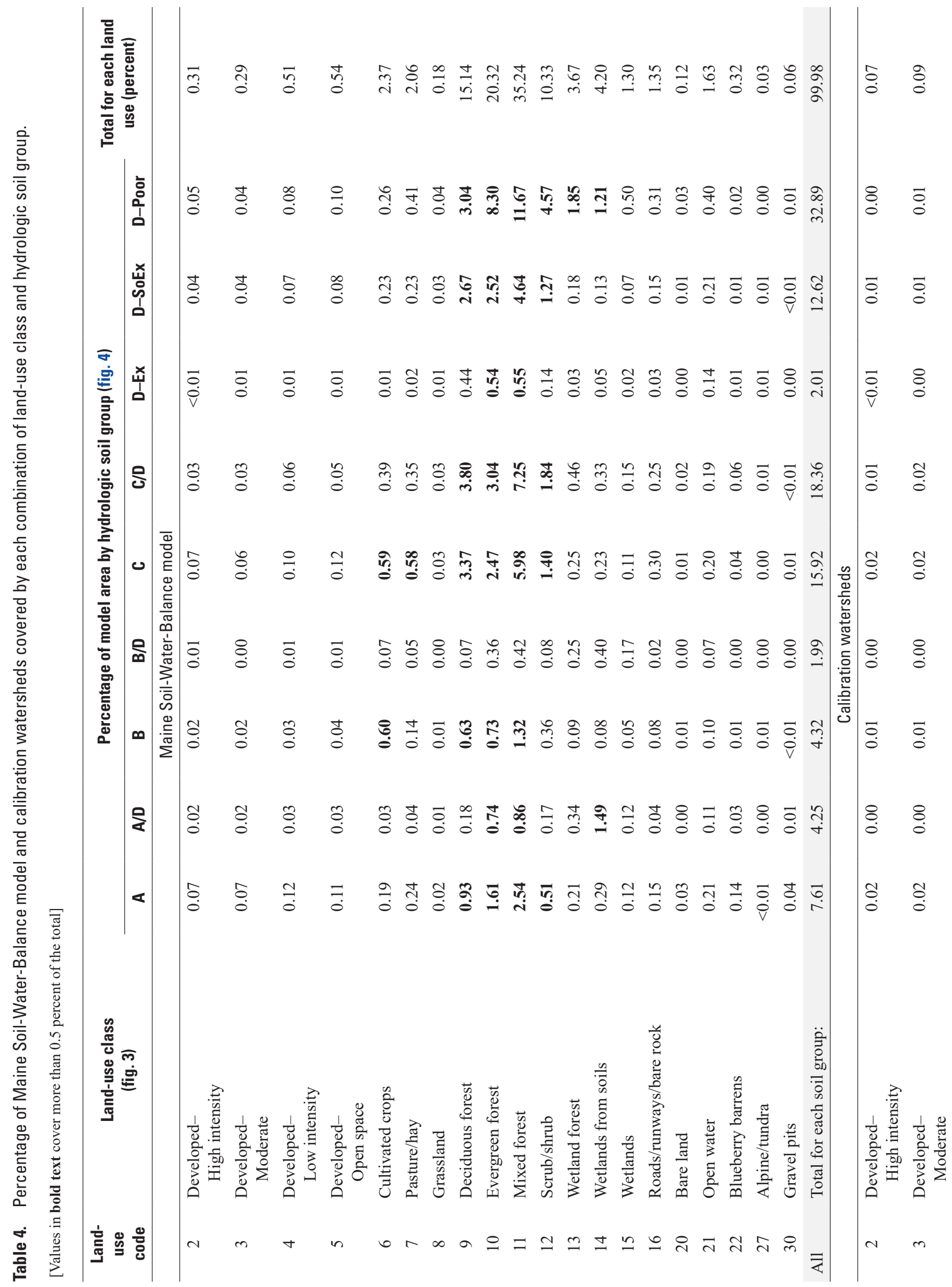




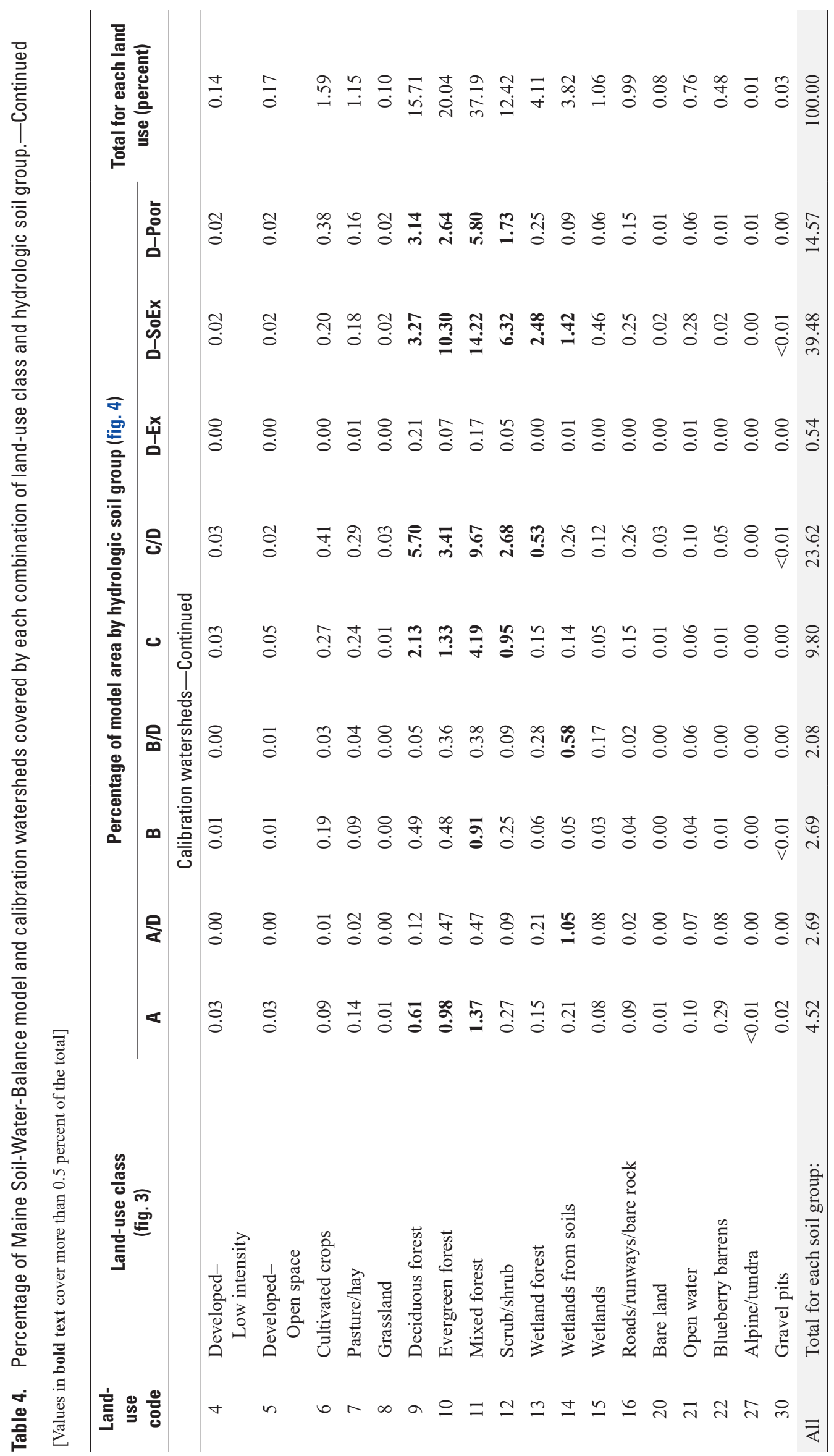




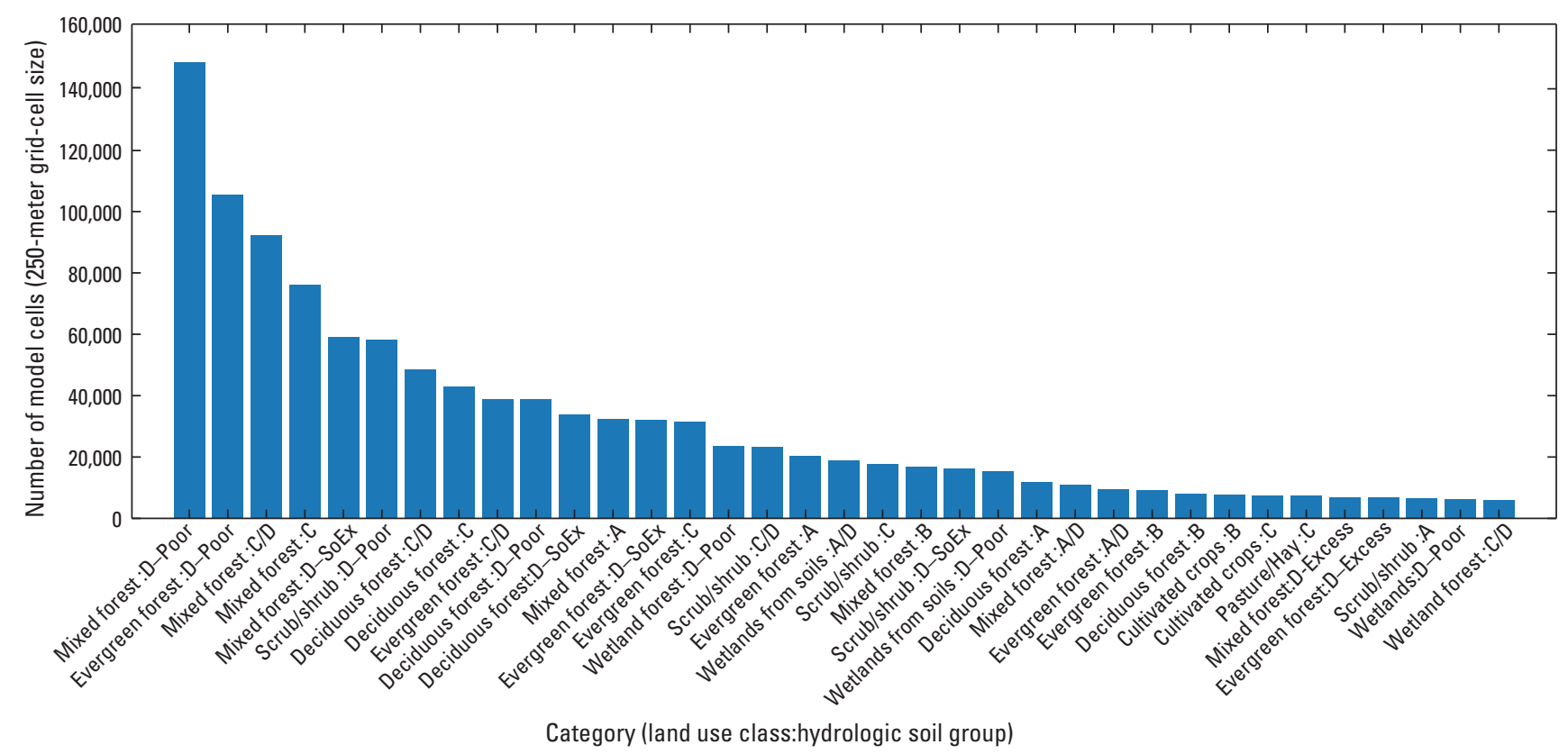

Figure 5. Abundance of land use class:hydrologic soil group categories for the top 35 categories in the Maine study area.

in Canada. Impacts of this zone on the modeled SWB potential recharge are discussed in the "Simulated Recharge for Maine, 1990-2015" section.

\section{Lookup Tables and Control File}

The Maine SWB model uses two lookup tables to calculate the water balance terms: the primary land-use lookup table, and a second irrigation lookup table, which was used for the ET calculations using the FAO56 ET method (Westenbroek and others, 2018; Allen and others, 1998), which gives much greater control over the ET simulation as compared to the default Thornthwaite-Mather method (Thornthwaite and Mather, 1957). The primary land-use lookup table contains values for runoff curve numbers, maximum daily recharge, and rooting depths for each combination of land-use class and hydrologic soil group in the model (example shown in table 5; see full table, appendix table 1.2). With 19 land-use classes and 9 hydrologic soil groups, the Maine SWB model has 171 different values for each of these categories. Lookup values for interception (if used) vary with land use and growing season and are also included in the SWB land-use lookup table. The irrigation land-use table (see example in table 6; see full table, appendix table 1.3) includes plant growth settings such as crop coefficients ( $\mathrm{K}_{\mathrm{cb}}$ values for onset of growth, plant maturity, and senescence), growing-season lengths, and bare soil evaporation settings for every land-use class.

\section{Calibration of Maine Soil-Water Balance Model}

The model calibration used an automated parameter estimation approach, using highly parameterized inversion and PEST software (Doherty and Hunt, 2010; Welter and others, 2015 ) to fit the curve number, maximum daily recharge, and rooting depth values in the SWB lookup table and several parameters that control the ET calculations using the FAO56 method (Allen and others, 1998). The land-use lookup table values, as well as irrigation table lookup table values and multipliers for groups of irrigation table lookup values were treated as model parameters and adjusted during the calibration (appendix tables 1.2 and 1.3). The PEST software orchestrates the running of several hundred model runs, adjusting parameter values in an iterative fashion, until the objective function is satisfactorily minimized, and further changes in parameter values do not provide substantial improvements in the overall model fit.

Calibration targets included all three major components of the water budget: recharge, direct runoff, and ET. Initial attempts at model calibration using only the recharge and direct runoff water-budget components for calibration targets resulted in a fairly good model fit, but once the ET calculations were compared to known values, the misfit was unacceptably large. These initial attempts used the Thornthwaite and Mather (1957 ET calculations that the SWB software uses by default. Switching to the FAO56 method (Allen and others, 1998) and adding ET observations and parameters that control the ET calculation helped achieve a more wholistic model fit. 


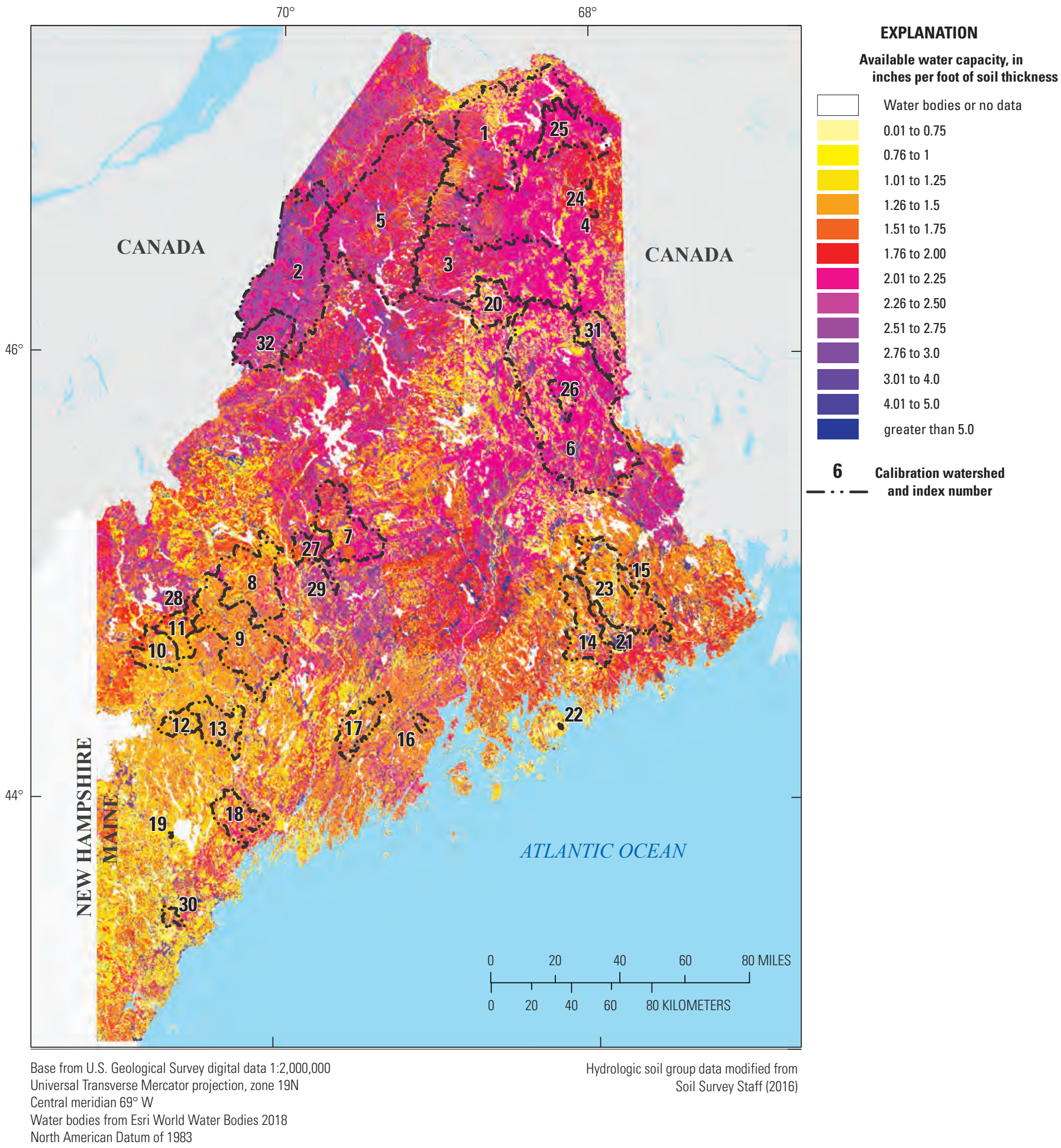

Figure 6. Available water capacity of the Maine Soil-Water-Balance model and calibration watersheds. 


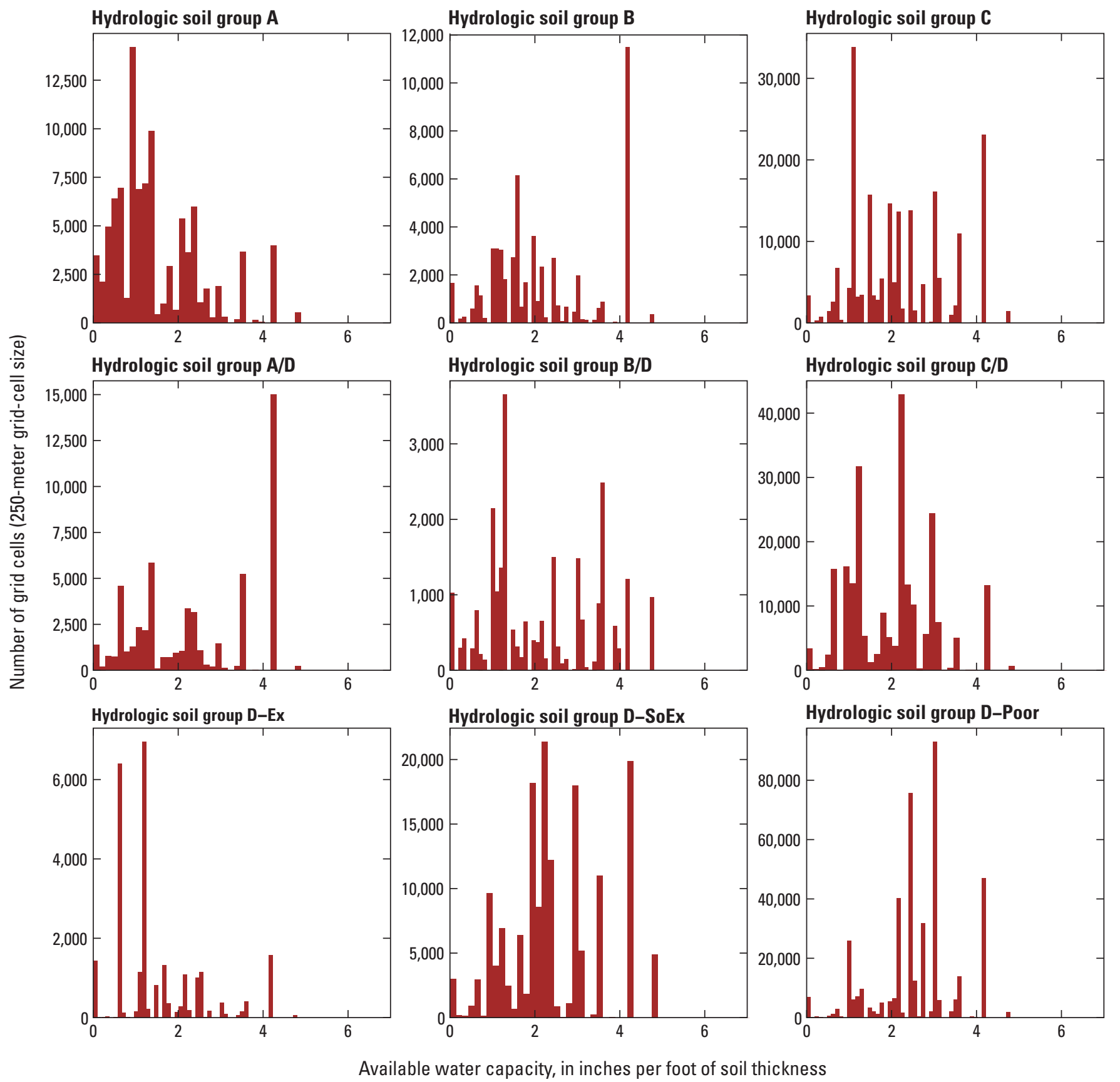

Figure 7. Distribution of available water capacity values for each hydrologic soil group in the Maine Soil-Water-Balance model. 


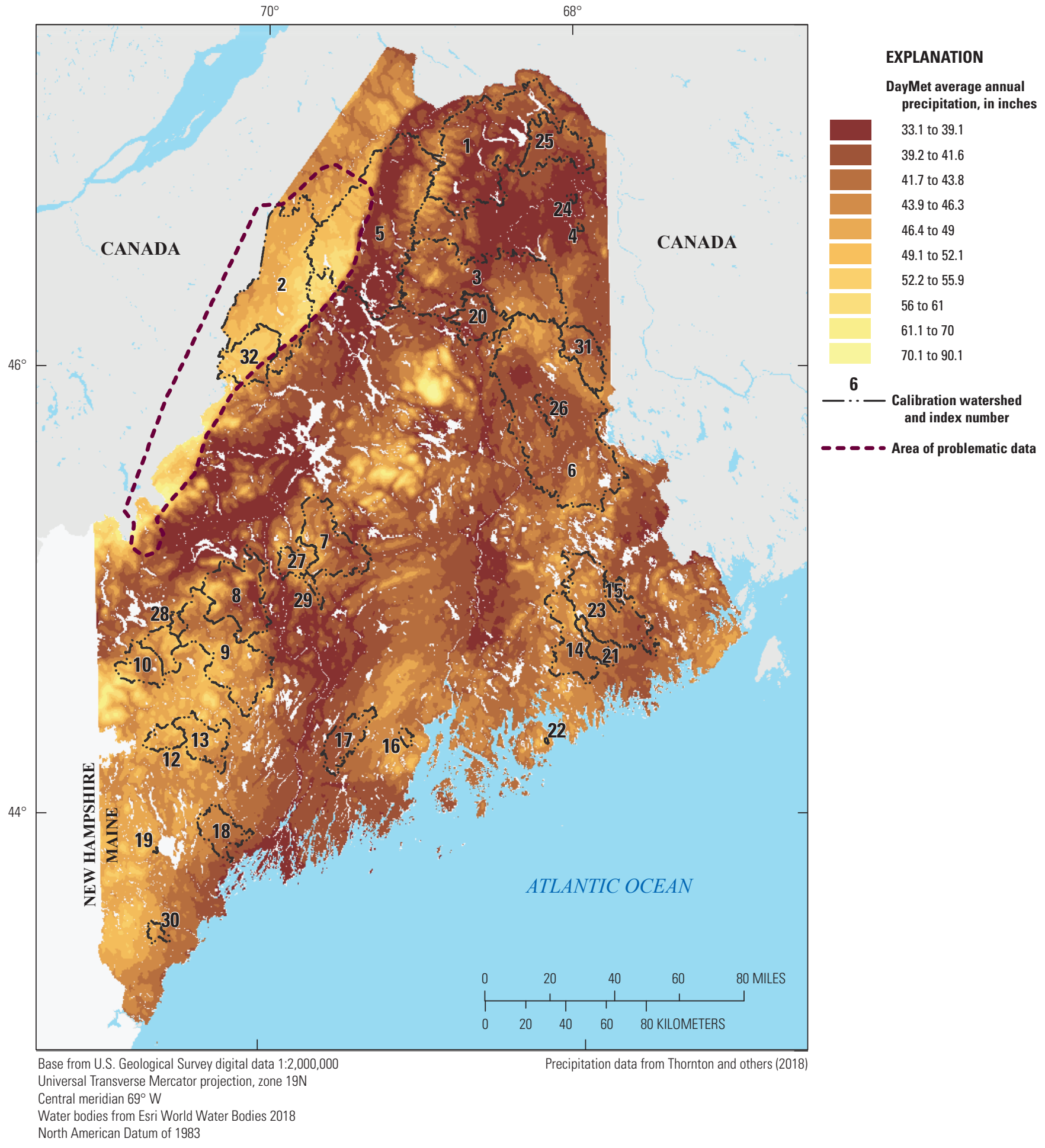

Figure 8. DayMet average annual precipitation, 1991 to 2015, for the Maine Soil-Water-Balance model and calibration watersheds. 


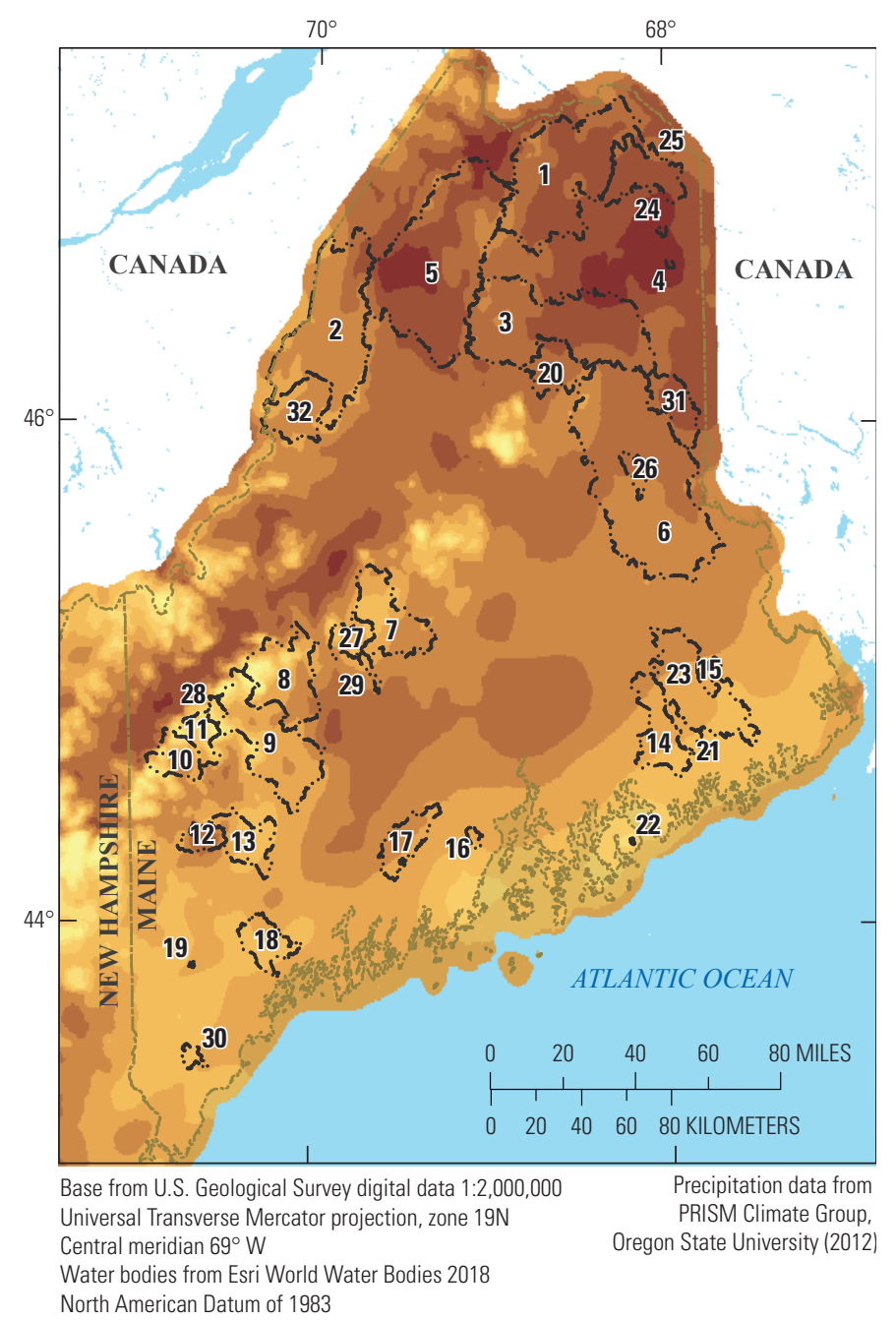

EXPLANATION

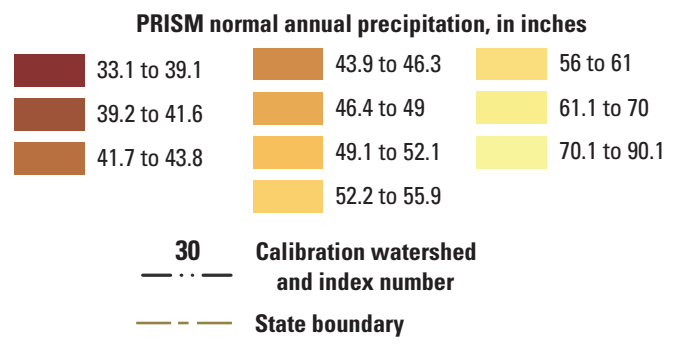

Figure 9. Parameter-elevation Regressions on Independent Slopes Model (PRISM) normal annual precipitation 1981 to 2010, for the Maine Soil-Water-Balance model and calibration watersheds.

\section{Parameterization}

PEST's use of highly parameterized inversion allows for the use of hundreds of model parameters, while not introducing problems of parameter insensitivity and correlation. The primary parameter set for the Maine SWB model consisted of values in the land-use lookup table: 515 parameters for runoff curve numbers, maximum daily recharge, and rooting depths. The interception values were fixed at zero and not used as parameters. The irrigation lookup table accounted for another 28 parameters that controlled the ET calculations: $13 \mathrm{~K}_{\mathrm{cb}}$ values and 15 multipliers for bare-soil evaporation applied across sections of the table (543 total parameters; see appendix 2, tables 2.1 and 2.2, available for download at https://doi.org/ 10.3133/sir20195125, for complete lists).

To reduce the number of parameters from the lookup table evaluated during parameter estimation, a threshold of 0.1 percent of the domain $(1,200$ model cells) was set so that values for combinations of land-use class and hydrologic soil group that were not widespread in the model (and would provide little value to the overall calibration) were not adjusted during the parameter estimation runs. Initial values for the lookup table were based on pilot calibration exercises for small subset areas of the Maine SWB model. The final parameter estimation runs used 223 adjustable parameters.

SWB model runs and the calibration were performed on a Linux-based operating system, with a Windows 10 emulator, and on a Windows 10 operating system. Parallel processing of the calibration runs was conducted through HTCondor on a dedicated cluster of several hundred computer cores.

PEST uses singular value decomposition during the iteration runs to group parameters into super-parameters, which reduces potential parameter correlation issues that can plague other parameter-estimation procedures.

\section{Calibration Targets and Weights}

In total, 3 sets of calibration targets for 32 calibration watersheds (fig. 1; table 1) were used as input to the parameter-estimation runs, which used 13 years of data (2000-12). (The first year [2000] is a model spin-up year; the actual calibration time period is from 2001 to 2012 [12 years].) A shortened period (as compared to the 1991 to 2015 total time period) for calibration was used for increased overall efficiency and to avoid excessively long calibration run times. The 2000-12 time period was chosen because it includes periods of low flows (2001-3) and periods of high flows (2005 and 2008). The watersheds selected for inclusion in the calibration met the following criteria: flows at the streamgage location represented natural conditions and were unregulated. Four of the watersheds that were used are above the optimal size for hydrograph separation (500 square miles); consequently, the observations from these watersheds were weighted lower than the others. A minimum was not placed on the number of years of streamflow record for the watersheds, which had between 4 and 12 years of record for the calibration. 


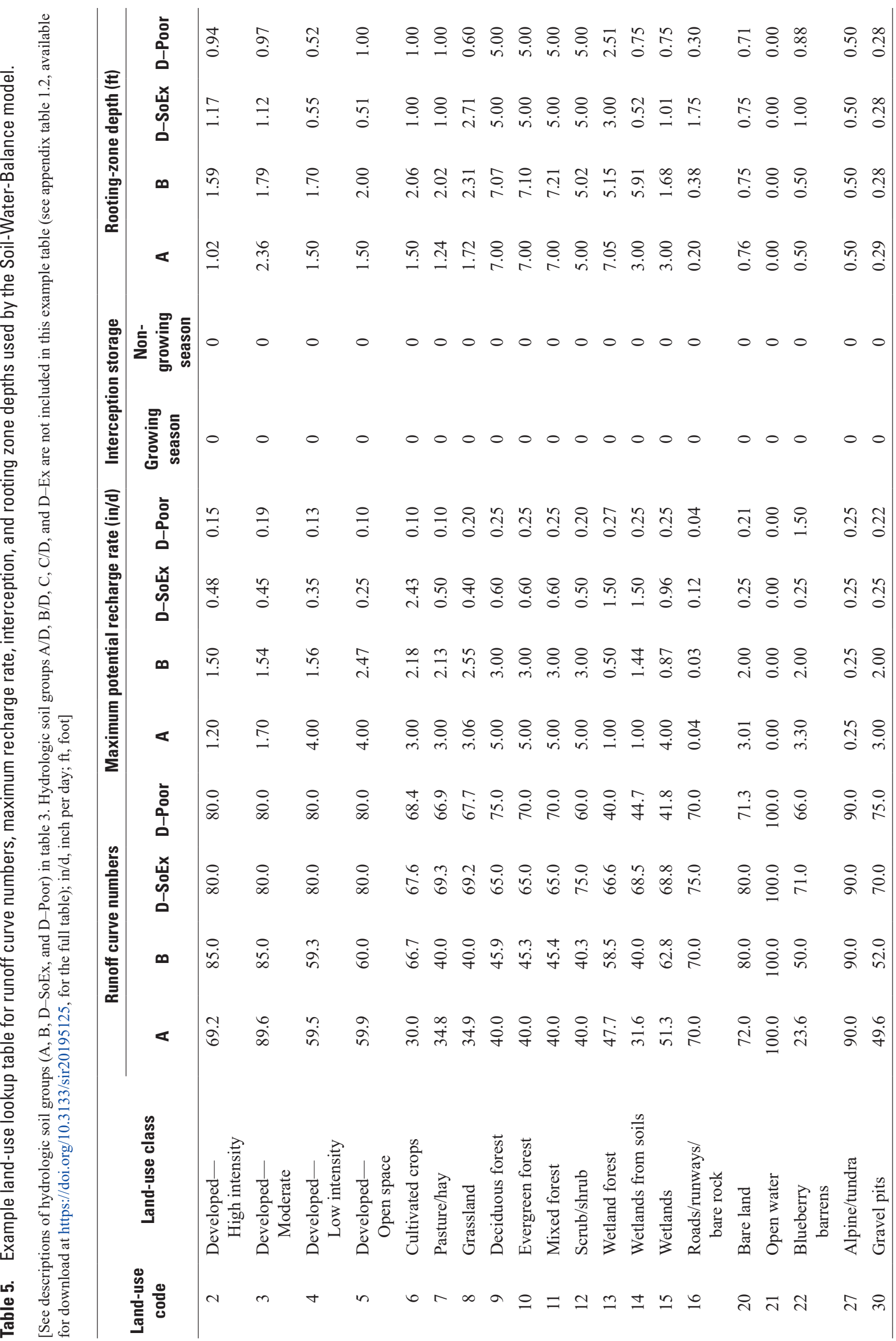




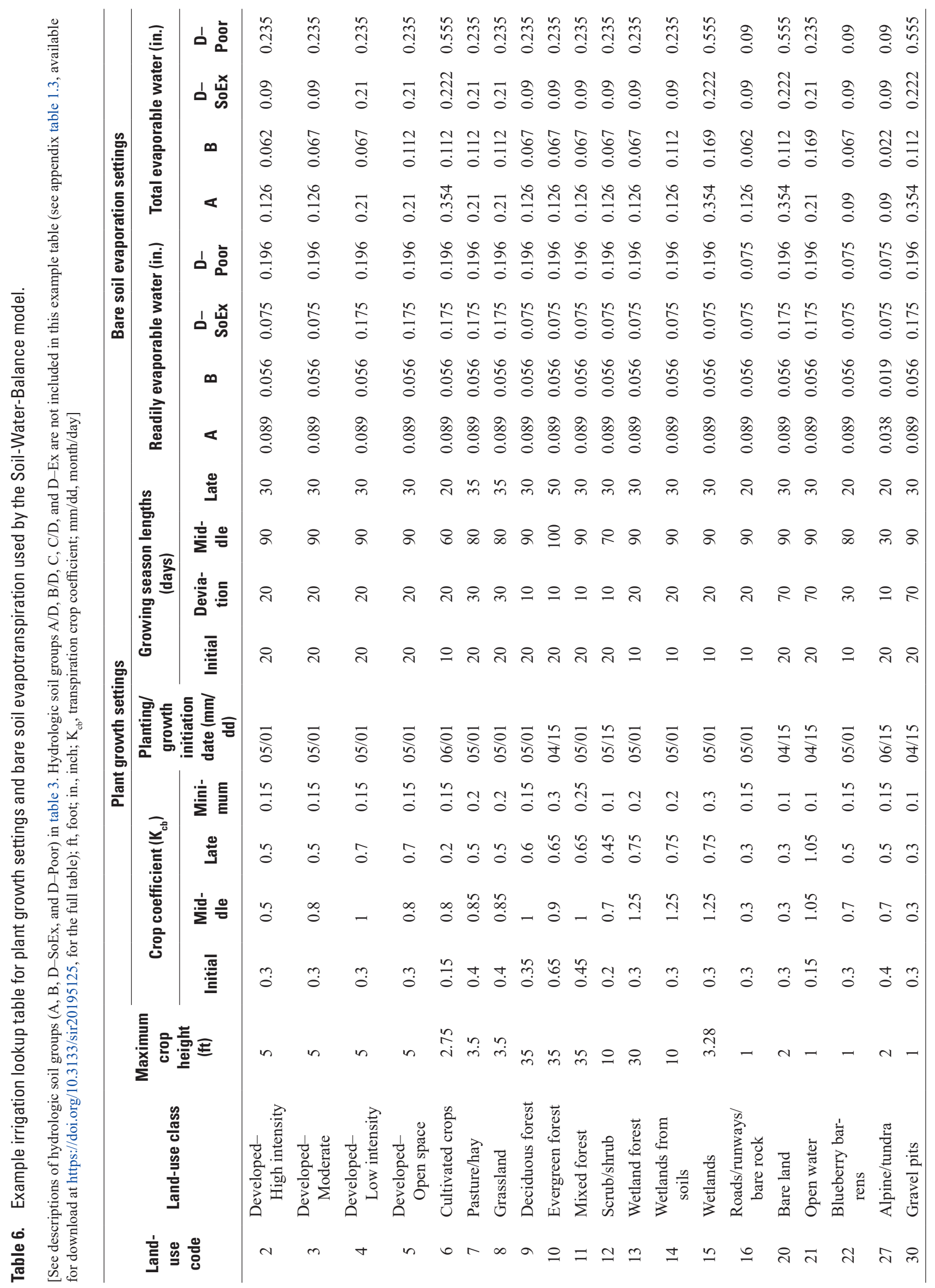




\section{Development of Observation Values}

As noted earlier, the observations used for the calibration included evaluations of annual recharge and direct runoff from base-flow separation analysis for 32 watersheds and annual ET data from a national ET gridded dataset (Reitz and others, 2017) for the same watersheds. Although some of the watersheds had less than the 13 years of streamflow data for the 2000-12 period, the ET data were used for all years in all watersheds.

Many methods exist for base flow-separation analysis to divide streamflow records into base flow (recharge) and direct runoff components. A common means of determining recharge and (or) runoff for a gaged watershed is by performing a hydrograph analysis, either using base-flow separation or other techniques, such as recession-curve displacement. The recession-curve displacement method was explicitly developed to determine episodic recharge from a hydrograph (Rutledge, 2007). Base flow-separation techniques use the base-flow component of the hydrograph as an approximation of groundwater discharge and, by conservation of mass, groundwater recharge (assuming that the surface-water and groundwater basin boundaries are coincident for a measurement point). The non-base flow component of the hydrograph is the direct runoff component. Base flow-separation methods assume that recharge and groundwater discharge is a continuous process, whereas the recession-curve displacement method analyzes the hydrograph assuming that recharge is an episodic event in response to precipitation events (Rutledge, 2007; Healy, 2010; Barlow and others, 2015) This study used nine methods (see appendix 2 for details) to evaluate the streamflow records (each method divides the total streamflow into a base-flow and direct runoff component), and the median of the nine calculation outputs was used as the calibration target for annual recharge (base flow) and annual runoff observations.

The ET observations were extracted from the Reitz and others (2017) data, which are national datasets of monthly estimates of ET, modeled using a modification of the operational Simplified Surface Energy Balance (SSEBop) approach. Watershed data were extracted from the monthly grids, averaged across each watershed for each month, and the monthly data summed to get an annual ET observation for each year over each watershed.

The base flow-separation analysis provided 315 recharge observations and 315 runoff observations for the 12-year calibration period. Although not all watersheds had the full 12 years of streamflow data, ET data were available for the full 12 years for every watershed, resulting in 416 ET observations.

\section{Weights on Observations}

Parameter estimation methods require that observations each be given a weight, which establishes its relative influence in the calibration process. One method of calculating weights of an observed value is to estimate the error or variance of the measurement used as the observation (Hill and Tiedeman, 2007; Anderson and others, 2015). Because the recharge and runoff observations were each calculated from a population of nine possible values, the variance $\left(\sigma^{2}\right)$ was used for each of the observations, with some modifications, as discussed later in this section. The initial weight of each observation was set at $1 / \sigma^{2}$.

Variances on recharge and runoff were generally lower during years of relative drought (2001-2), and higher during wet years (2005 and 2008). Also, some watersheds generally had higher variances than others, especially smaller ones with flashier runoff (calibration watersheds 15 [Old Stream], 22 [Otter Creek], 26 [Wytopitlock Stream], 16 [Ducktrap River], and 29 [East Branch Wesserunsett Stream]; fig. 1; table 1).

Initial weights on the ET observations were calculated from the variance of the ET across all years of the calibration. This method gave each watershed's ET observation the same weight across all years and made the weight proportional to the year-to-year variability of the ET estimates at a given location.

While attempting to make the observation weights as objective as possible, the modeler may make adjustments to balance the weights in the model. This will create a set of weights that best fulfills the purpose of the model (Anderson and others, 2015). Some adjustments were made to the Maine SWB observation weights to balance the influence of some outliers, to reduce the influence of very large watersheds that stretch the recommended limits on base flow-separation methods, and to reduce the influence of watersheds on the northwest border with Canada that fell in the zone of anomalous precipitation patterns (calibration watersheds 2 [North Branch Penobscot River] and 32 [St. John River]; fig. 1; table 1). Finally, after the analysis of preliminary calibration runs, it was determined that watershed 19 (Stony Brook) may have significant groundwater underflow beyond the streamgage; thus, the runoff and recharge observations for that watershed were given zero weight in the final calibration. The ET weights as initially calculated were scaled to be proportionate with the final weights for the recharge and runoff observations so that the model considered each set of observations fairly equally during the calibration.

The final dataset of observations used in the calibration included 268 weighted recharge and runoff observations (each) and 366 weighted ET observations, for a total of 902 weighted observations. The final observed values and weights on each observation are given in appendix 2 (table 2.6, available for download at https://doi.org/10.3133/sir20195125). 


\section{Parameter Estimation}

Parameter estimation refers to the use of software to find the best fit solution of parameter values to reduce the model error, or lack of agreement between the measured and the model simulated values for each observation. The residual (measured value minus the simulated value) for each observation is multiplied by the observation weight, squared (making each value a positive number), and summed (Anderson and others, 2015). The model objective function, or phi $(\Phi)$, is the sum of the squared residuals for the model. The combination of parameter values with the lowest possible objective function thus constitutes the best-fit model. The PEST software (Doherty and Hunt, 2010; Doherty, 2004) was used in the calibration of the Maine SWB model. PEST uses information about the model parameters that are set up to run thousands of model runs to find the best fit model. The model runs were controlled and organized using the HTCondor computer cluster at the T.C. Chamberlin computing center at the Wisconsin USGS office.

The modeler controls which parameters will be adjustable during the estimation runs and how much to allow parameters to vary. The upper and lower bounds, within which PEST is allowed to test alternative values, are set for all the parameters in the model. Upper and lower bounds used for the runoff curve numbers, maximum potential recharge, and plant rooting depths used by the SWB lookup table were set using the modeler's best judgement and values used in other SWB models. Upper and lower bounds for the adjustable parameters for the FAO56 ET lookup table were set after a literature search on the possible ranges of values that would be reasonable for Maine. The complete list of parameters used, whether they were adjustable in the model, and the upper and lower bounds are provided in appendix 2 (tables 2.1 and 2.2).

Initial estimation runs were done that allowed PEST to use the full range of the parameter bound in the best-fit calculations. However, this resulted in some parameters being estimated at their furthest possible limits, not at a most "reasonable" value. PEST allows the modeler to use their knowledge of the system to further reign in the parameter adjustments, so the final values are as close as possible to values the modeler thinks are most reasonable. Tihkonov regularization is a process that can be used in PEST to find the best fit of parameters with a penalty to moving the parameters too far away from a "preferred" value (Anderson and others, 2015). This method prevents highly parameterized models from becoming over-fit, which may result in smaller model error but may not represent reality well (Anderson and others, 2015). The model error of a model using regularization will not be as small as one without but should result in a more parsimonious model. The final Maine SWB runs were done using Tihkonov regularization, after evaluating the parameter values of the initial runs.

The PEST parameter estimation also made use of singular value decomposition (SVD) to reduce the problems that can be introduced in a highly parameterized model of highly correlated parameters and insensitive parameters. SVD groups parameters into super parameters during the estimation runs and uses these super parameters to reduce the correlation and insensitive parameter issues. A more detailed discussion on the use of SVD can be found in Anderson and others (2015).

\section{Model Fit-Comparison to Observations}

The model calibration process compared 902 weighted observations of recharge, runoff, and ET to the model output for 2001-12. The model fit for the final calibrated parameters is evaluated by comparing the observed values of recharge, direct runoff, and ET to the model output values and to the residuals. The overall mean model error (average of all residuals) was $0.39 \mathrm{in}$. The mean of the absolute value of the residuals, or the mean absolute error (MAE), was $2.32 \mathrm{in.} \mathrm{The}$ root mean squared error (RMSE) for the calibrated model overall is $3.14 \mathrm{in}$. For the recharge observations only, the overall mean model error was 0.03 in., the MAE was 2.64 in., and the RMSE was 3.43 in. The runoff observations are not as well fit: the overall mean model error was $1.06 \mathrm{in}$., the MAE was 2.75 in., and the RMSE was 3.78 in. The ET observations have a smaller range in values and a smaller range in errors: the RMSE for ET observations was 2.27 in., and the MAE for ET observations was 1.77 in., whereas the mean overall model error for ET was 0.16 in.

Figure $10 \mathrm{~A}$ illustrates the total model error, showing the observed and simulated values, as compared to the 1:1 line and a fitted line that represents the actual mathematical relation between the observed and simulated values. In a perfectly calibrated model that reproduced all observations precisely, all the points would line up with a 1:1 relation between the observed and simulated values. The Nash-Sutcliffe efficiency (NSE) test (Nash and Sutcliffe, 1970) is a normalized statistic that indicates how well the observed versus simulated values fits the 1:1 line (Moriasi and others, 2007; Trost and others, 2018). A Nash-Sutcliffe efficiency value of 1.0 would indicate a perfectly calibrated model; the value for the Maine SWB model is 0.75 . The simulated model results line up closely to the $1: 1$ line, indicating a relatively accurate model where the residuals do not deviate significantly from the line in one direction or another. Figure $10 B$ shows the plot of residuals. The probability plot correlation coefficient (PPCC) test (Helsel and Hirsch, 1992) evaluates the normality of the residuals. The PPCC test for the Maine SWB model indicated a normal distribution of residuals across the 1:1 line (PPCC value $=0.98401$, probability [ $p$-value] less than 0.0001$)$. In other words, the residuals for the overall model are not very skewed. Another common statistic used to determine the fit of the model is the correlation coefficient squared $\left(r^{2}\right)$. The $r^{2}$ value for the simulated versus observed values for the Maine SWB model is 0.76 .

The use of Tihkonov regularization, as discussed earlier, prevents an "overfit" model, where a closer model fit is obtained at the expense of keeping parameter values close to the modeler's judgment of most reasonable values. A larger $r^{2}$ 
and smaller RMSE could have been obtained without using regularization, but this could have led to model overfitting and unreasonable parameter values.

Considering each type of observation separately (fig. 11) shows that the observations for recharge (fig. 11A,D) fall most closely to the 1:1 line, but the residuals (fig. 11D) are somewhat skewed (the NSE for the recharge observations alone was 0.58 , and the PPCC test indicated normality of the residuals, $p$-value $=0.0065$ ). At the high end of observed recharge (more than $25 \mathrm{in} / \mathrm{yr}$ ) the model underpredicts potential recharge, shown by having a positive residual. At low amounts of observed recharge (less than $15 \mathrm{in} / \mathrm{yr}$ ), the model overpredicts some of the values, shown by having a negative residual. Between 15 and $25 \mathrm{in} / \mathrm{yr}$, the model does not consistently over- or under-predict the potential recharge. The runoff simulated values have the greatest degree of deviation from the observed values (fig. 11B), and the residuals (fig. 11E) deviate more from the observed values for watersheds and years with high amounts of runoff ( $\mathrm{NSE}=0.52$, PPCC indicated normality of the residuals, $p$-value $<0.001$ ). This indicates that the model has difficulty partitioning sufficient water into the runoff part of the water budget when overall runoff is quite high (over 20 in. of observed runoff). The Maine SWB model performs better for runoff when the modeled runoff is less than $20 \mathrm{in} / \mathrm{yr}$.

The ET observations (fig. 11C) are equally balanced across the 1:1 line, but the residuals (fig. $11 F$ ) are quite skewed between lower and higher observations (NSE $=0.26$, PPCC test indicated non-normal residuals at alpha $[\alpha]=0.05$ ). The model estimates more ET than the SSEBop observations at the lower range of observed values and too little at the higher range of ET observed values. Comparisons of SSEBop
ET estimates to ET flux towers (Reitz and others, 2017; Kim, 2017) have shown that at low ET measurements, the SSEBop method underestimates ET, and at higher ET measurements, the SSEBop method overestimates ET. The estimation bias for the SSEBop method could account for at least some of the skewness in the SWB model results because the errors are in the same direction as they are when comparing actual ET measurements to the SSEBop estimates.

Another graphical approach to evaluating the model performance is a comparison of the observed and simulated three major water-budget components by year for individual watersheds. Six calibration watersheds distributed across the State were selected to illustrate the model performance on a watershed basis (fig. 12). The calibration watersheds, in a clockwise order around the State from north to southwest (fig. 1; table 1), are watersheds 5 (Allagash River; fig. 12A), 31 (Meduxnekeag River; fig. 12B), 14 (Narraguagus River; fig. 12C), 17 (Sheepscot River; fig. 12F), 12 (Little Androscoggin River; fig. 12E), and 8 (Carrabassett River; fig. 12D). All but the Meduxnekeag River watershed have 12 years of complete observations; watershed 31 has more limited recharge and runoff observations, spanning 2004-12. The bars for simulated and observed ET and recharge are just about identical in several years for every watershed. The bars for the observed and simulated runoff are the most unequal, and some watersheds seem to have a consistent bias - in the Allagash River watershed, the modeled runoff is generally higher than observed (and the recharge lower), which could be an artifact of the base flow-separation methods used to calculate the observations (this watershed has a relatively high amount of surfacewater storage, and the hydrograph-separation techniques
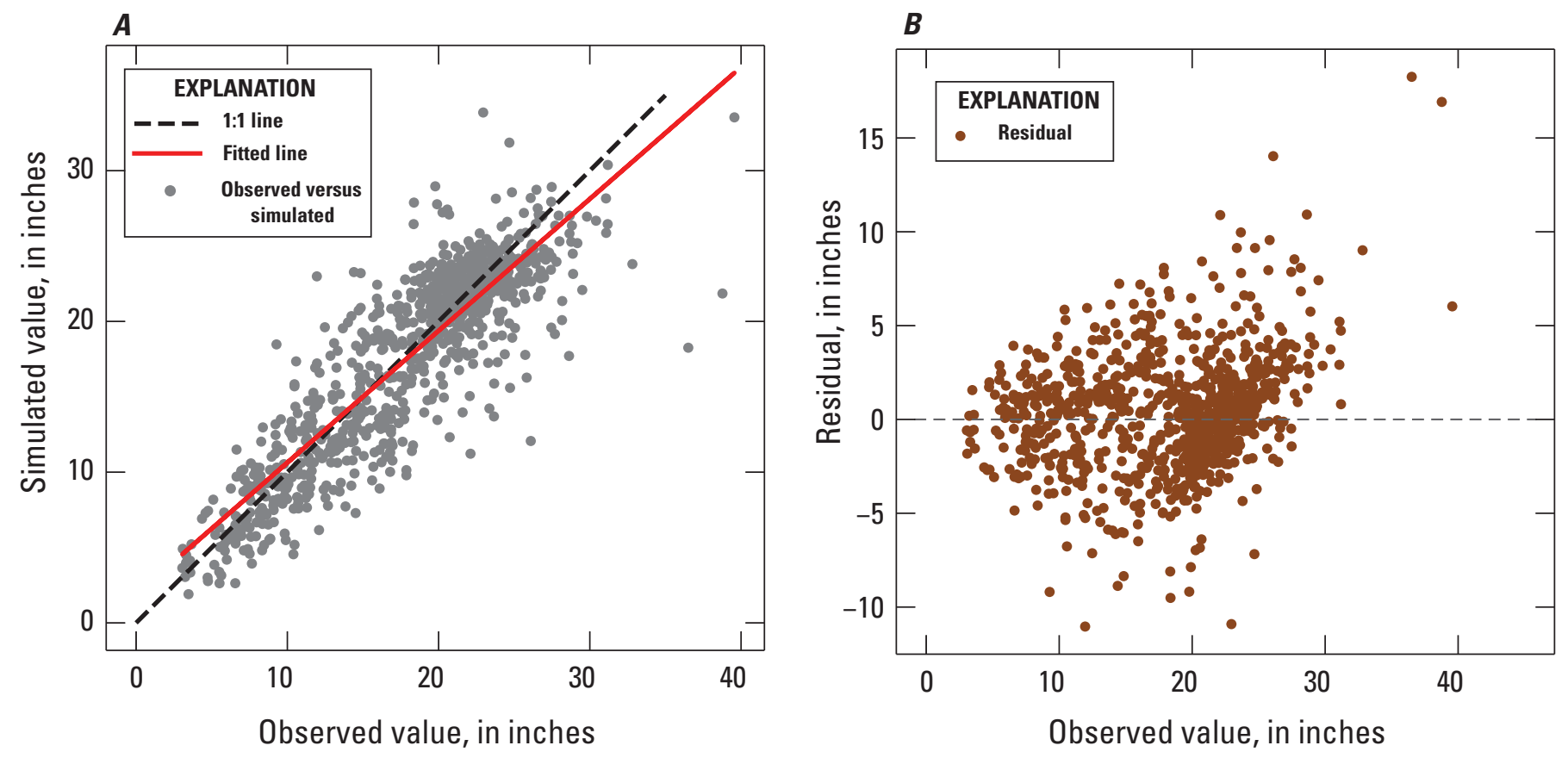

Figure 10. Overall model calibration results. $A$, observed and simulated values for all observations. $B$, model residuals. 

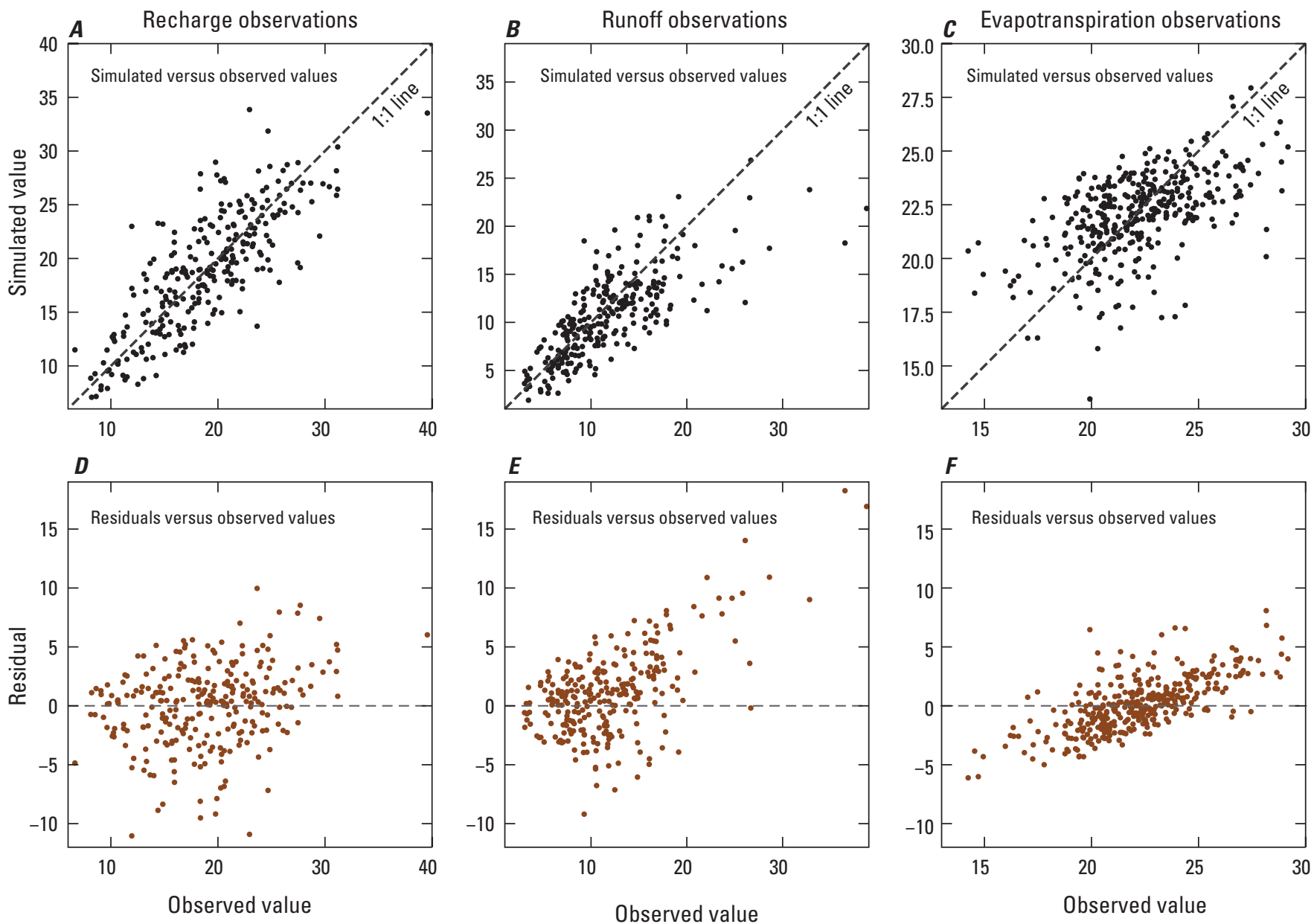

Figure 11. Relations between observed and simulated values for watershed recharge, runoff, and evapotranspiration for 32 calibration watersheds during 2000-12, and plots of residuals compared to observed values. Simulated versus observed values of $A$, recharge observations; $B$, runoff observations; and $C$, evapotranspiration observations. Residuals versus observed values of $D$, recharge observations; $E$, runoff observations; and $F$, evapotranspiration observations.

may confuse slow surface-water outflow from lakes and wetlands with groundwater discharge). The Carrabassett River watershed has the opposite-more recharge is modeled than expected, and less runoff, especially during years of high precipitation (2005-6). This watershed has a high proportion of sandy group A soils near its mouth; it is possible that the streamgage does not capture 100 percent of the recharge, and that some may exit the watershed as underflow. Overall, each watershed has its own unique set of circumstances that may help to explain variations in the degree to which the observed values of recharge and runoff agree with the simulated values.

Assuming that the streamgage for each of these calibration watersheds captures all the direct runoff and recharge in the basin (which is a good assumption for most of the watersheds), and that the remaining incoming precipitation becomes ET as estimated by the SSEBop dataset, the total height of the observed bars should equal the total incoming precipitation over the watershed, plus any snow storage that is held over from the previous year. The precipitation totals range from about $35 \mathrm{in} / \mathrm{yr}$ in a few watersheds in 2001-2, to about $70 \mathrm{in} / \mathrm{yr}$ in 2005 in several watersheds. Similarly, the total height of the simulated bars represents the total input water (DayMet precipitation) plus or minus any changes in soil or snow storage over the watershed. Because of the combination of storage effects and other possible model errors, the total DayMet precipitation does not always agree with the observed totals from the sum of the observations.

\section{Parameter Sensitivity and Influence}

An important measure of the sensitivity of a model to variations in model input parameters (when the true value of the parameter is not known) is a parameter sensitivity analysis. Sensitivity of the model to the parameter values is calculated by PEST as part of the calibration process. The PEST output for the calibration using SVD enables an analysis of the total sensitivity of the model observations, for all the 
A. Allagash River watershed (no. 5)

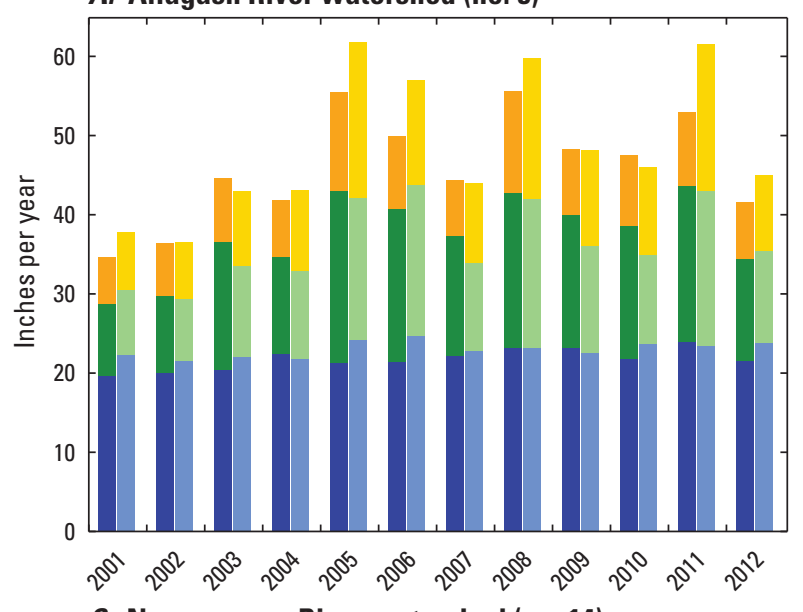

C. Narraguagus River watershed (no. 14)

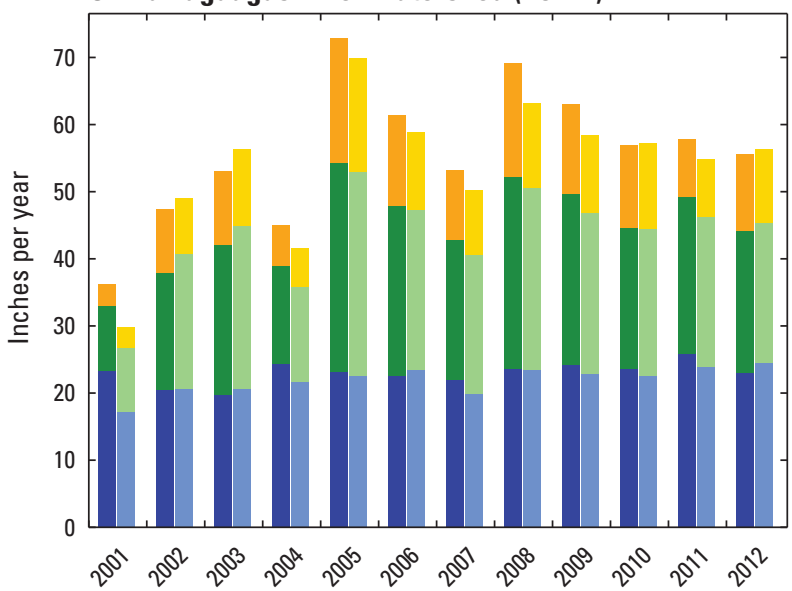

E. Little Androscoggin River watershed (no. 12)

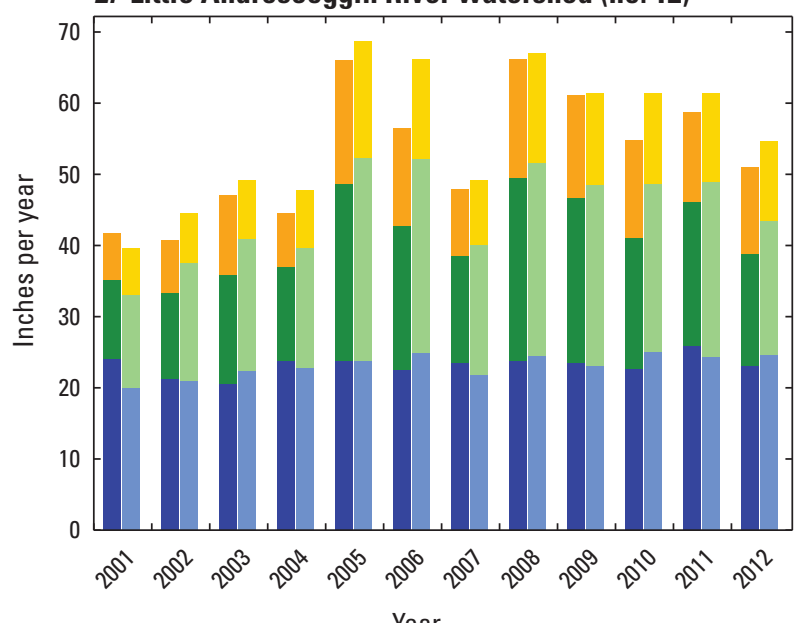

B. Meduxnekeag River watershed (no. 31)
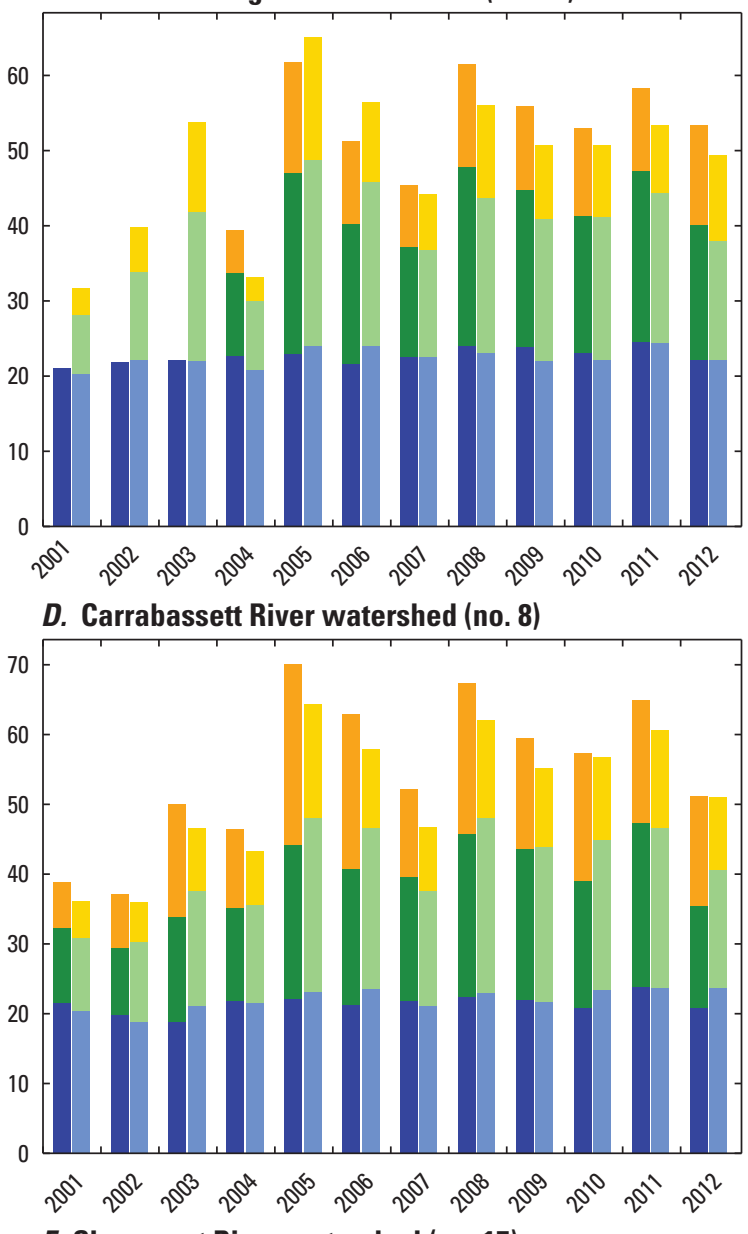

F. Sheepscot River watershed (no. 17)

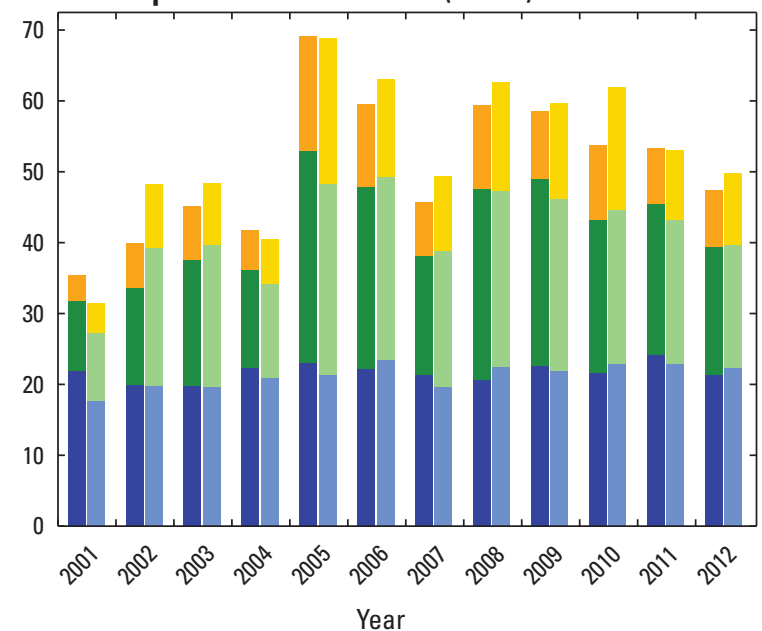

\section{EXPLANATION}

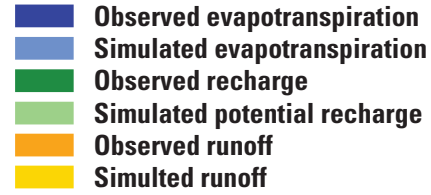

Figure 12. Annual comparisons of observed and simulated recharge, runoff, and evapotranspiration for 2001-12 in six calibration watersheds. $A$, Allagash River watershed, no. 5. B, Meduxnekeag River watershed, no. 31. C, Narraguagus River watershed, no. 14. D, Carrabassett River watershed, no. 8. E, Little Androscoggin River watershed, no. 12. F, Sheepscot River watershed, no. 17. 
parameter types together, and for just the recharge observations by themselves. Parameter identifiability (Doherty and Hunt, 2009; Anderson and others, 2015) is a type of sensitivity analysis that analyzes the amount of information contained by the observations about each parameter. The calculation of this statistic uses SVD on the matrix expressing the sensitivity of every observation to every parameter. The result is unaffected by parameter correlation, which makes it a better statistic than weighted sensitivities (Doherty and Hunt, 2009).

Considering all the observations together, the model is most sensitive to the $\mathrm{K}_{\mathrm{cb}}$ mid-season growth ET parameters (table 7; fig. 13A). This is understandable because these values directly control how much of the total soil moisture is moved by plants into the atmosphere during the height of the growing season and therefore how much is left in the soil to become potential recharge. The runoff curve numbers are the second most sensitive group (table 7; fig. 13A), and these operate at the beginning of the daily calculations to route excess water from the land surface to runoff, directly controlling what is available for plant uptake and potential infiltration.

Because the primary product of this study is the potential recharge to groundwater, a separate identifiability calculation was done for the observations of recharge. The recharge simulations are most sensitive to the runoff curve numbers (table 7; fig. 13B), closely followed by the mid-season $\mathrm{K}_{\mathrm{cb}}$ ET parameters and maximum potential infiltration rates. The recharge calculations are more sensitive than the overall model to the maximum potential infiltration rate and rooting depth parameters. This follows from the fact that some of the observations in the overall model, the runoff calculations in particular, do not rely as heavily on these parameters.

Table 7. Identifiability of parameters and parameter groups for the Maine Soil-Water-Balance model.

$\left[\mathrm{K}_{\mathrm{cb}}\right.$, transpiration crop coefficient $]$

\begin{tabular}{lccc}
\hline \multicolumn{1}{c}{ Parameter group } & $\begin{array}{c}\text { Total identifiability of } \\
\text { parameters in group }\end{array}$ & $\begin{array}{c}\text { Number of parameters } \\
\text { in group }\end{array}$ & $\begin{array}{c}\text { Recharge identifiability of } \\
\text { parameters in group }\end{array}$ \\
\hline $\mathrm{K}_{\mathrm{cb}}$ mid-season values & 7.94 & 13 & 6.71 \\
Runoff curve numbers & 6.17 & 41 & 6.89 \\
Maximum potential recharge rate & 3.93 & 77 & 5.95 \\
Rooting depths & 2.64 & 77 & 3.07 \\
Soil evaporation factors & 2.55 & 11 & 1.33 \\
$\mathrm{~K}_{\mathrm{cb}}$ edge season values & 1.06 & 4 & 1.05 \\
\hline
\end{tabular}



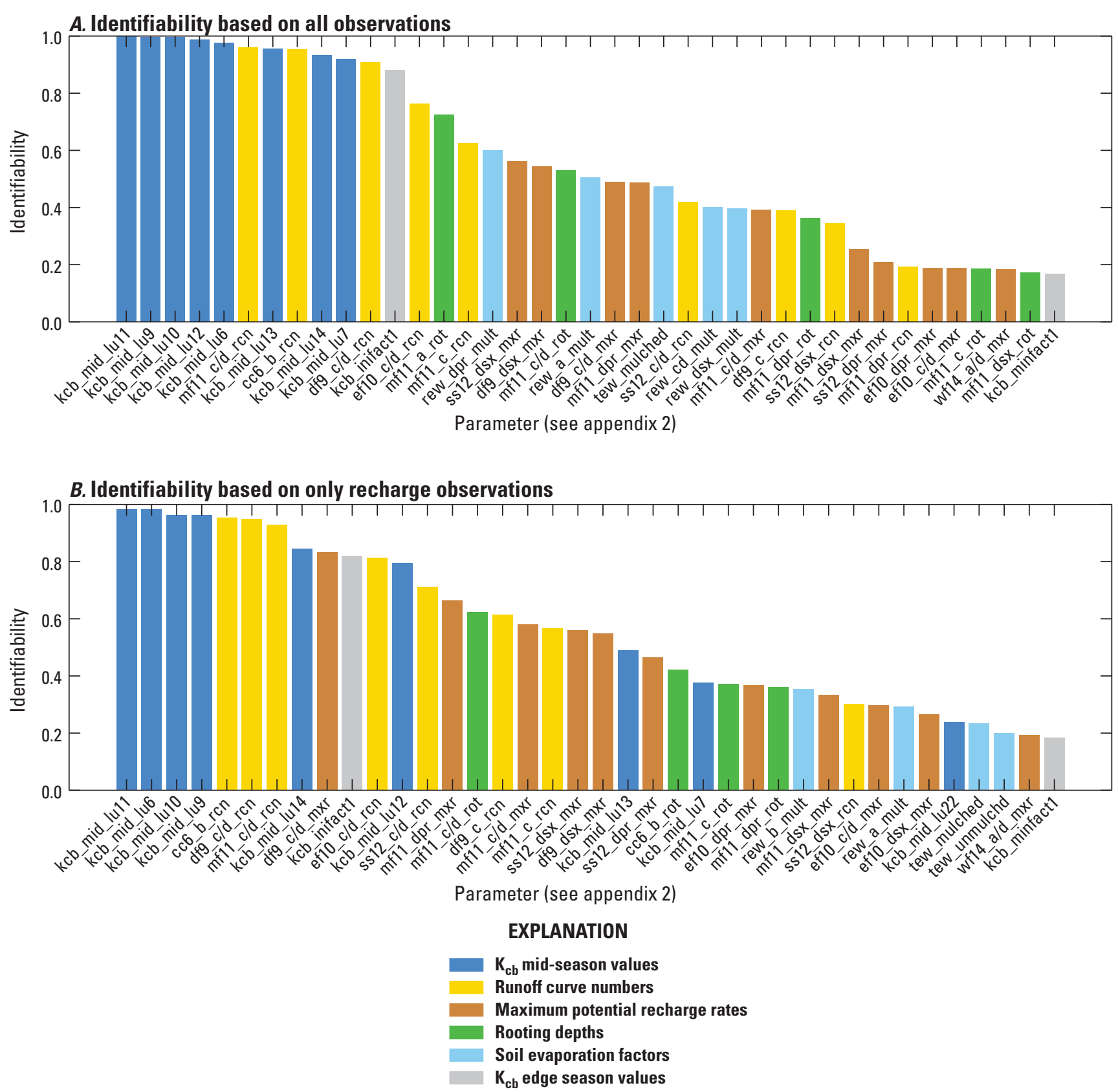

Figure 13. The identifiability of the top 40 most-sensitive parameters used in the Parameter ESTimation model calibration, by parameter group (appendix 2). A, Calculated using all observations (recharge, runoff, and evapotranspiration). $B$, Calculated using only recharge observations. 


\section{Groundwater Recharge Estimates for Maine, 1991-2015}

Using the best-fit set of parameters from the calibration runs, the Maine SWB model was run for 25 years, from 1991 to 2015 , using a $250-\mathrm{m}$ grid-cell size. The 25 annual grids were used to calculate the 25 -year mean annual potential recharge, median annual potential recharge, and the minimum and maximum potential recharge for the 25-year simulation. A Monte Carlo exercise (Tonkin and Doherty, 2009) was done to determine the potential uncertainty in these grids, using a distribution of alternate parameter values that fall within a reasonable range of the calibrated values for all parameters. In total, 300 alternate model realizations were run, and the standard deviation of the potential recharge value at every pixel was calculated.

\section{Exclusion Zone}

The anomalous DayMet data, discussed above in the descriptions of the model input, proved to make calibrating the model difficult. During the parameter estimation process, the two watersheds falling almost completely within this area were removed from the calibration process because their observations did not contribute to any improvements in the model fit and continually contributed a large amount to the degree of misfit of the model during early calibration runs. Based on this and the discrepancy of the DayMet data as compared to the PRISM precipitation data, an "exclusion zone" was created and used to screen out the area in northwestern Maine from the final analysis because the calculated potential recharge values in this area are not considered representative of actual conditions.

\section{Recharge Grids-Annual Average and 25-Year Minimum, 25-Year Maximum Potential Recharge}

From the 25 -year simulation, the average annual potential recharge is represented by the mean and median annual potential recharge. The model grids were processed as described earlier in this report. A comparison was done to see if using the 250-m grid-cell size for the final grids gave a different result than using the 500-m grid-cell size used in the calibration, using the observation watersheds to test the annual grid outputs. At this scale, the median difference in the potential recharge was only 0.1 in., and 90 percent of the differences were within plus or minus 0.5 in., so the switch to using a 250-m grid-cell size does not introduce substantial changes in the overall results.

The statistical distributions of the values in the mean and median 25-year, 250-m grids are similar. The statewide average of the mean grid (7.7 in.) is just 0.2 in. more than the statewide average of the median grid (7.5 in.), and the statewide maximum for the mean was just 0.5 in. more than the statewide maximum for the median potential recharge. A histogram of each statewide grid (minimum, mean, median, and maximum), illustrates the overall distribution of potential recharge values across the State (fig. 14). The mean and median overall distributions are very similar, as noted above, because most values fall between 5 and about $30 \mathrm{in} / \mathrm{yr}$ across the State (fig. $14 A, B$ ). The statewide range in the minimum values is very compressed (about 2 to $20 \mathrm{in} / \mathrm{yr}$ ) — almost everywhere in the State experienced a drought-year low recharge less than $10 \mathrm{in} / \mathrm{yr}$ sometime during the 25 -year simulation period (fig. 14C). The statewide range in the maximum recharge experienced between 1991 and 2015 is much more variable, and most values are between 15 and 48 in/yr (fig. 14D). Very high recharge years are mostly driven by excessive precipitation, and the spatial variability in excess precipitation events would help to explain the greater range in maximum potential recharge across the State. Maps of the median, mean, minimum, and maximum estimated annual potential recharge are presented in figures 15 through 18.

A visual comparison of either of the spatial distribution of the average recharge (mean [fig. 15] or median [fig. 16]) to the average annual precipitation (fig. 8) suggests that the spatial distribution of potential recharge in Maine is driven largely by variations in precipitation patterns. Higher-than-average precipitation in the mountains in north-central Maine are mirrored by the higher-than-average potential recharge in the same areas. Other areas with higher precipitation in western Maine, central coastal areas and the furthest eastern coastal areas also have relatively high potential recharge. Conversely, the northern Maine, central Maine, and northwestern areas with lower-than-average precipitation also are mirrored by areas of lower-than-average recharge.

Keeping this in mind, there are also patterns in the potential recharge that are affected by the spatial distribution of the land-use class and hydrologic soil group categories (table 8). The land use:hydrologic soil group categories with the highest simulated median potential recharge include many land uses underlain by group A soils (sandy and well drained), particularly those land uses with low or little vegetation (blueberry barrens, developed, open space, shrub/scrub, and cropland, for example). The simulated median recharge for the categories with the 10 highest recharge values statewide range from 26.5 to $38.2 \mathrm{in} / \mathrm{yr}$. These values are not dissimilar to previously published values for sandy, well drained soils in Maine. A detailed analysis comparing the SWB simulated potential recharge with several published study areas in Maine is presented later in the report.

The categories with the lowest potential recharge estimates across the State include impervious-surface categories (roads/runways/bare rock) and forested land uses with poorly drained, low-permeability soils (D-Poor). Rates for the impervious surface categories compare favorably to previously published values for bedrock (Gerber and Hebson, 1996). The values for the forested:D-Poor categories are on the higher end of previously published values for clay soils in Maine, which have been estimated from 2 to $12 \mathrm{in} / \mathrm{yr}$ (Gerber and Hebson, 1996), see discussion below in the section on "Comparison of Average Recharge to Previous Studies." 

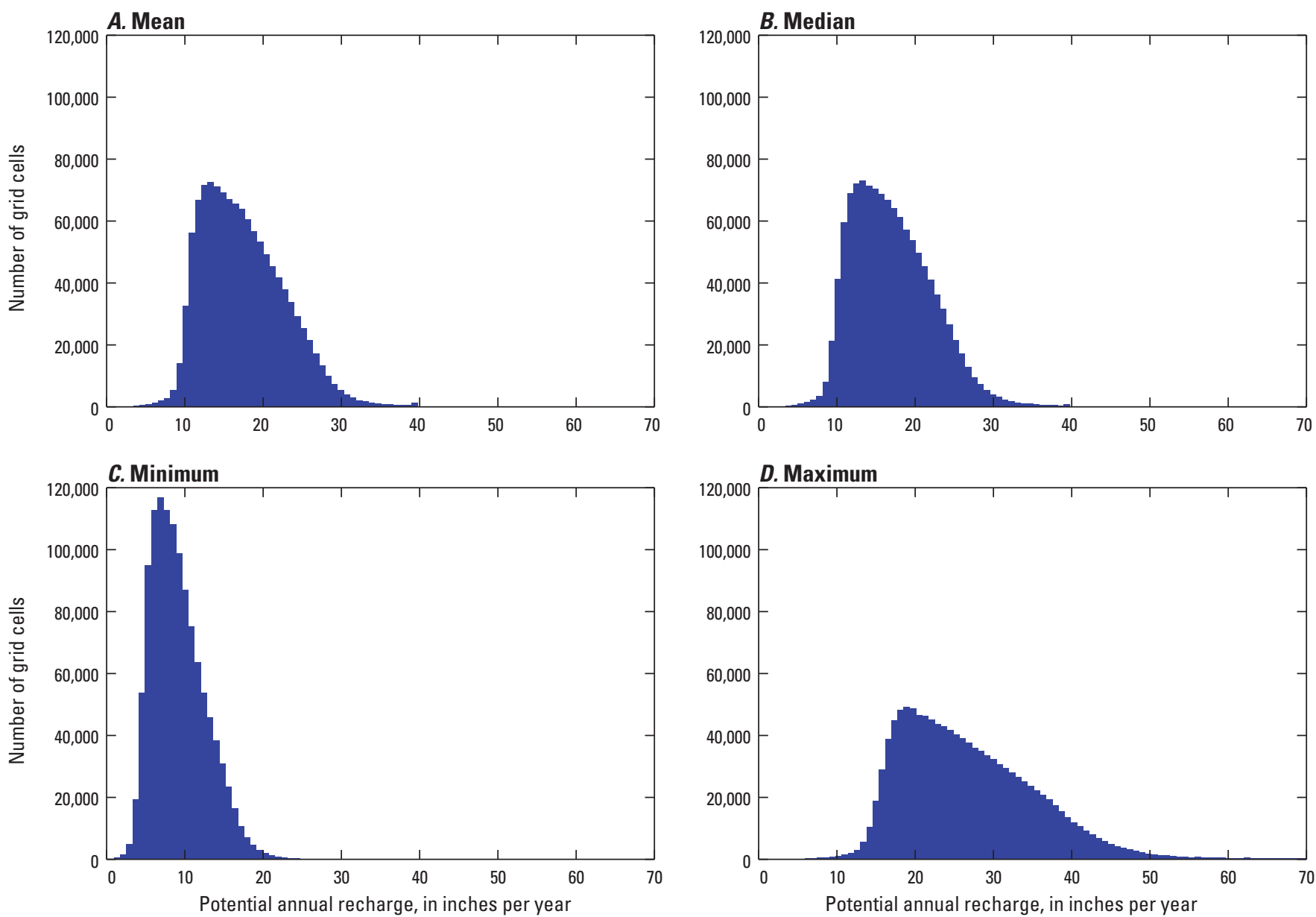

Figure 14. Range of 25-year modeled $A$, mean; $B$, median; $C$, minimum; and $D$, maximum potential annual recharge across Maine.

\section{Uncertainty of 25-Year Recharge Grids}

The primary reason for conducting uncertainty analysis is to improve decision-making by addressing the ability of a model to fulfill its stated purpose (Anderson and others, 2015). For this study, the purpose is to provide an estimate of potential recharge to shallow groundwater across the State, and the uncertainty analysis addresses the potential error in the estimates of the 25 -year average recharge grids. This section presents the overall spatial distribution of model uncertainty, global sensitivity to the most important calibration parameters, and a discussion of intrinsic uncertainty from the uncertainty in underlying datasets and model design.

\section{Calculated Uncertainty}

As a measure of the uncertainty in the calibrated model 25-year median annual potential recharge grid, a Monte Carlo analysis was performed, using 300 potential realizations of the suite of model parameter values, using the method of Tonkin and Doherty (2009; White and others, 2016; see above section on "Modeling Uncertainty Representation").
From each of the successful Monte Carlo runs (285 total), the 25-year median grid was calculated. The model fit of each run, as compared to the observation values used during the calibration, also was calculated. Any Monte Carlo run whose model fit fell outside a range of acceptable $\Phi$ values was discarded from the final analysis, resulting in 258 model realizations with acceptable combinations of parameter values. The range in $\Phi$ values for the "acceptable" runs was from 270 to 360 (the best-fit model from the PEST calibration had a $\Phi$ of 318). The model runs with unacceptably poor model fit included combinations of model parameter values that produced recharge estimates unlikely to represent actual conditions. Using the remaining 258 model realizations, cellby-cell statistics were generated, and the standard deviation of all possible values for each grid cell was recorded. As in the best-fit model, each median potential recharge grid was given a screening for anomalously high values before the overall standard deviation grid was calculated.

The resulting grid of standard deviation values (fig. 19) provides a quantitative measure of the uncertainty in the Maine potential recharge grids that is a result of uncertainties in the model parameter values. The overall model uncertainty distribution is graphically shown in figure 20 - the average 


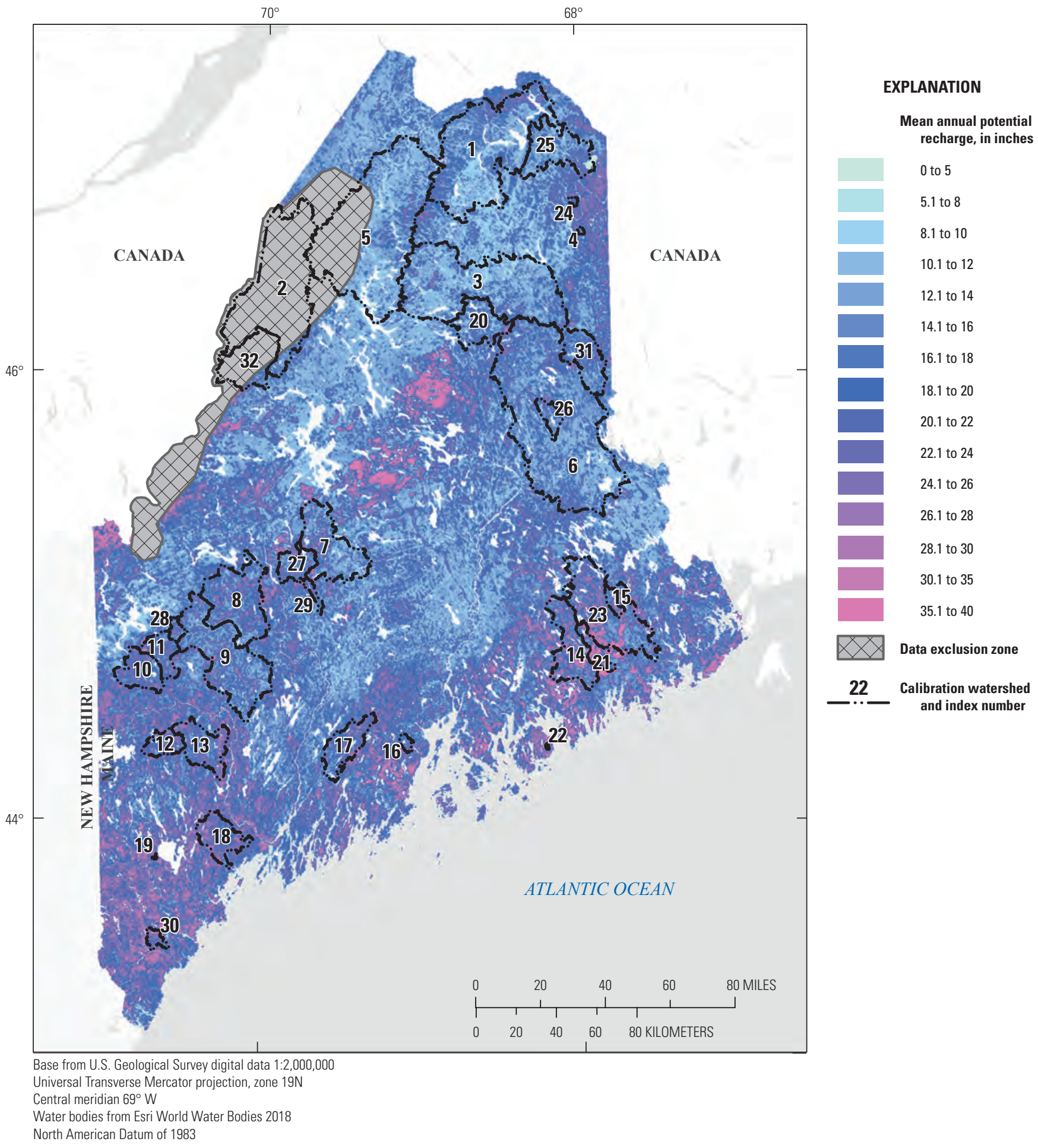

Figure 15. Simulated 25-year mean annual potential recharge to groundwater for Maine, 1991 to 2015. 


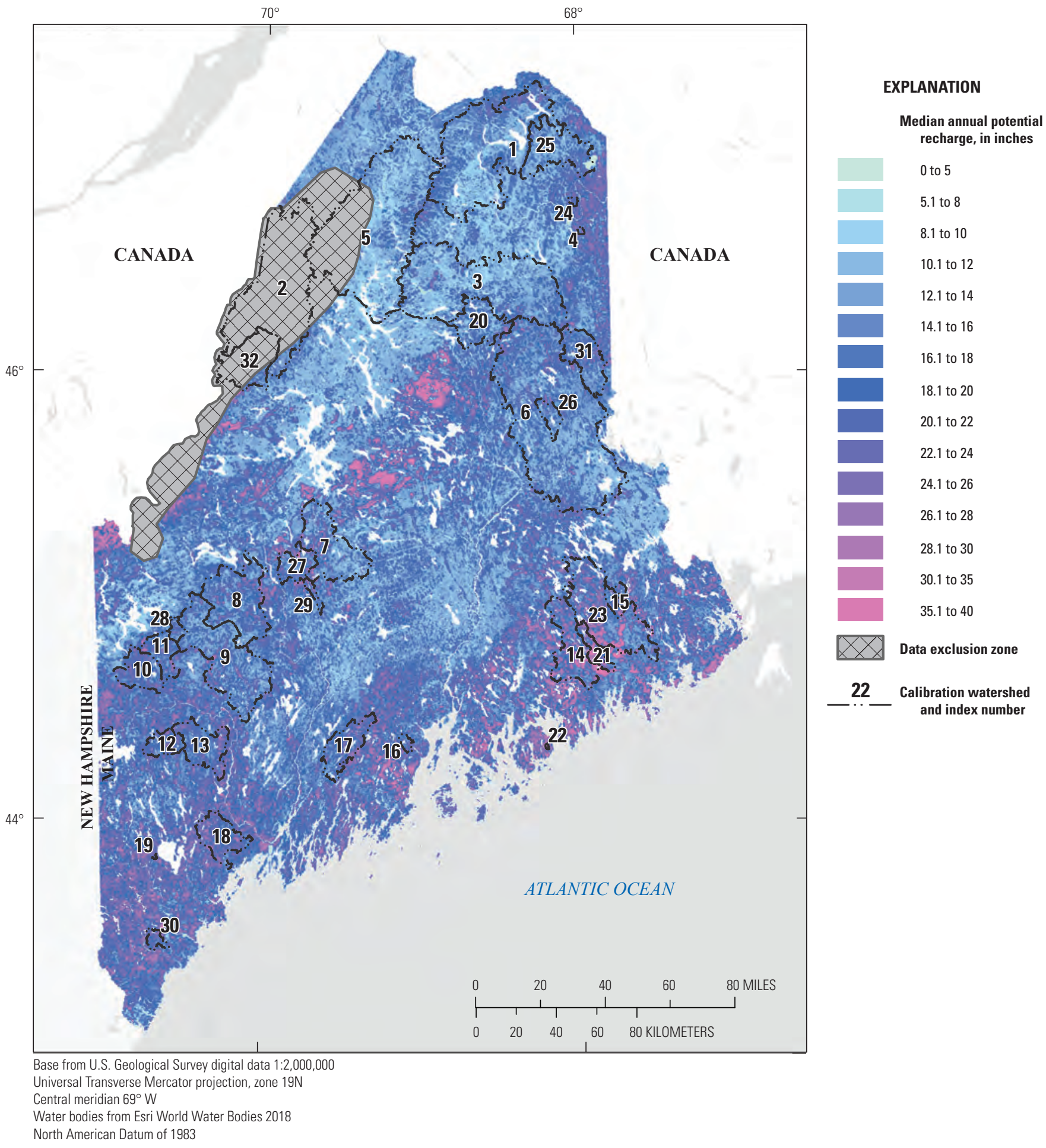

Figure 16. Simulated 25-year median annual potential recharge to groundwater for Maine, 1991 to 2015. 


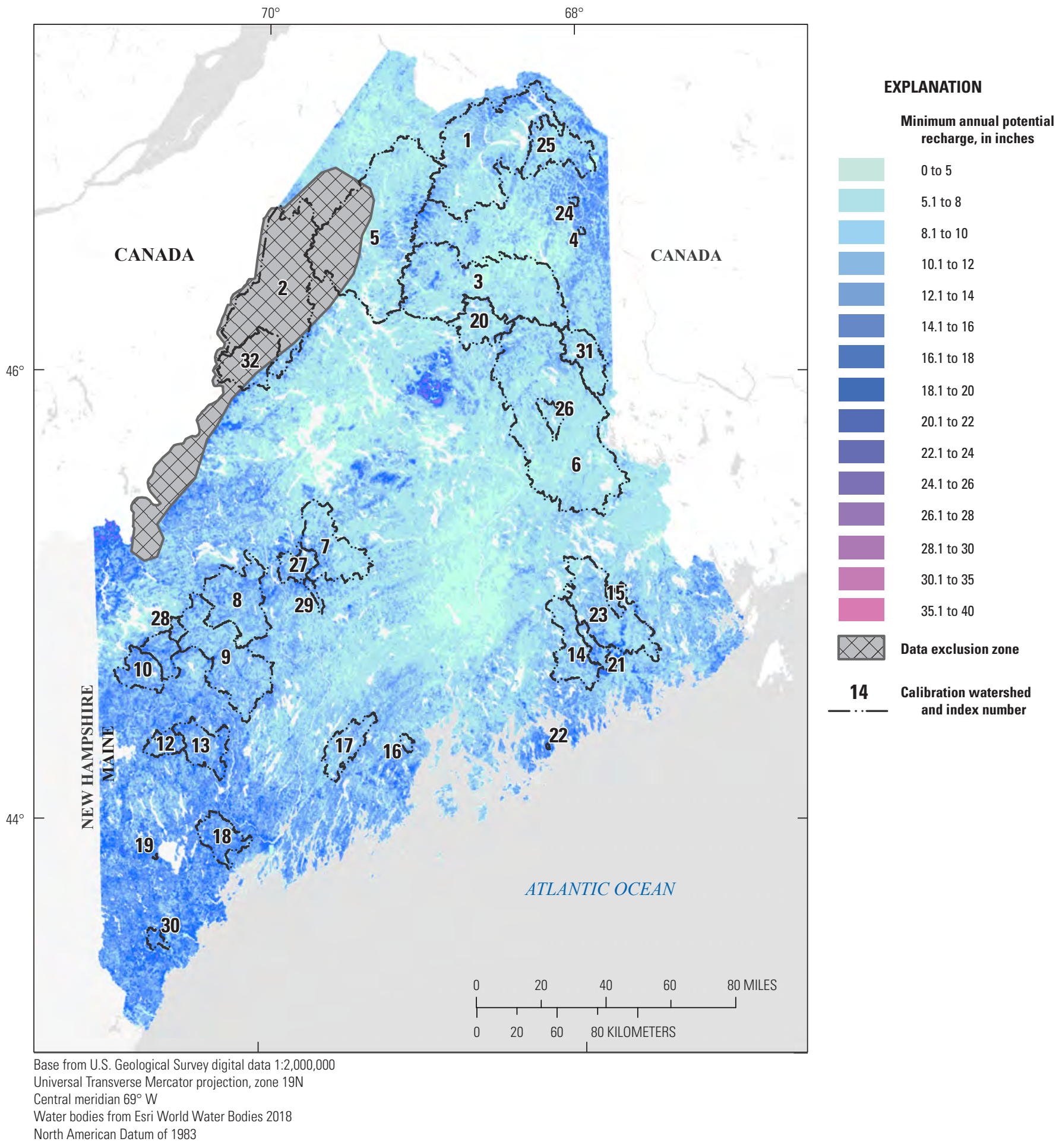

Figure 17. Simulated 25-year minimum annual potential recharge to groundwater for Maine, 1991 to 2015. 


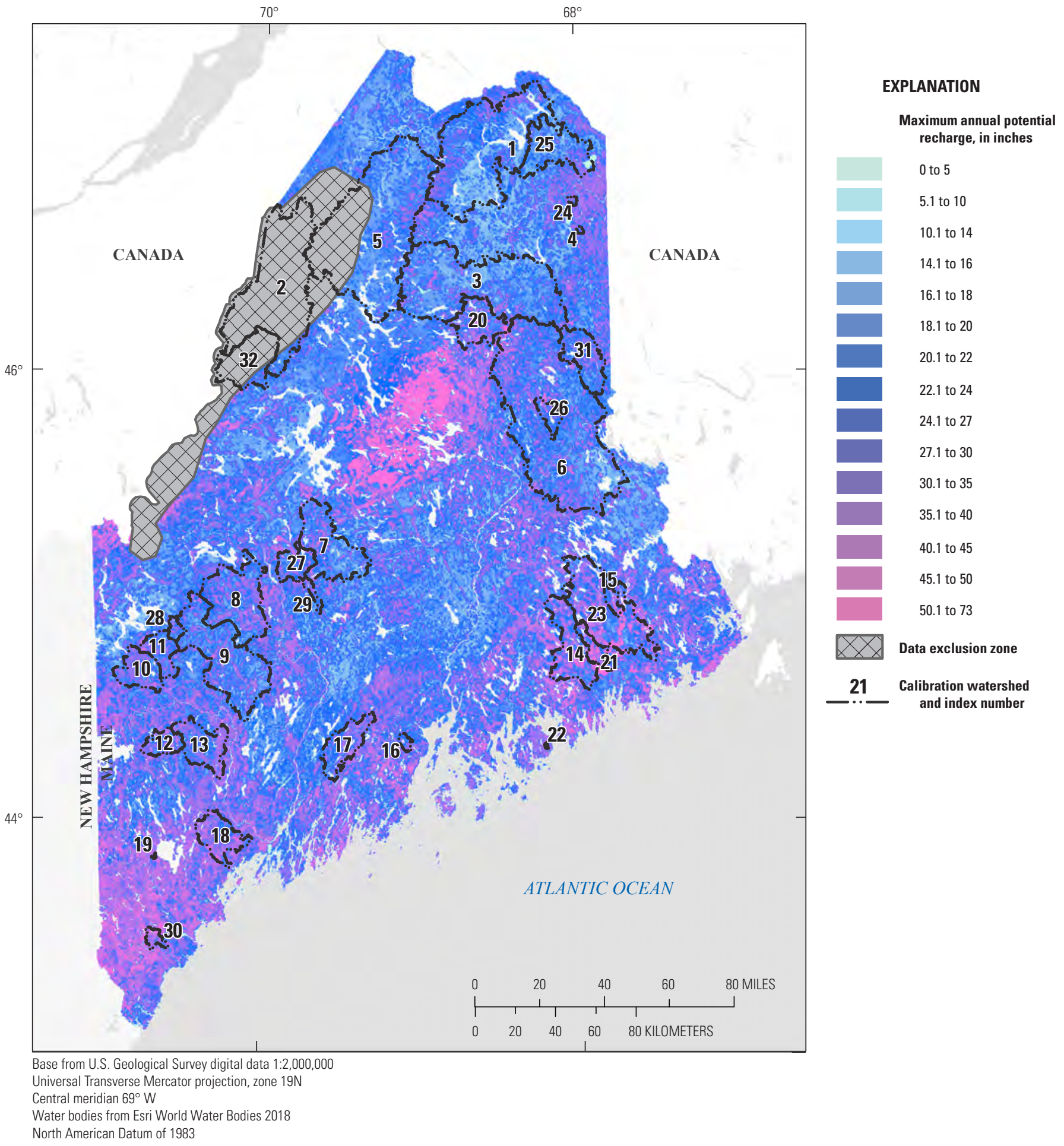

Figure 18. Simulated 25-year maximum annual potential recharge to groundwater for Maine, 1991 to 2015. 
Table 8. Median potential annual recharge rates and standard deviation for the highest and lowest 10 land-use class:hydrologic soil group categories in the Maine Soil-Water-Balance model.

[in., inch]

\begin{tabular}{|c|c|c|c|c|c|}
\hline Land-use class & $\begin{array}{l}\text { Land-use } \\
\text { code }\end{array}$ & $\begin{array}{l}\text { Hydrologic soil } \\
\text { group }\end{array}$ & $\begin{array}{l}\text { Median recharge } \\
\text { (in.) }\end{array}$ & $\begin{array}{l}\text { Standard deviation } \\
\text { (in.) }\end{array}$ & $\begin{array}{l}\text { Percentage of land } \\
\text { area in model }\end{array}$ \\
\hline \multicolumn{6}{|c|}{ Highest 10 categories } \\
\hline Blueberry barrens & 22 & A & 39.2 & 1.18 & 0.14 \\
\hline Developed-Open space & 5 & A & 30.42 & 1.67 & 0.11 \\
\hline Scrub/shrub & 12 & A & 30.37 & 1.65 & 0.52 \\
\hline Pasture/hay & 7 & A & 29.47 & 1.35 & 0.24 \\
\hline Developed-Low intensity & 4 & A & 29.31 & 1.98 & 0.12 \\
\hline Scrub/shrub & 12 & B & 28.47 & 1.53 & 0.36 \\
\hline Cultivated crops & 6 & A & 28.24 & 1.22 & 0.19 \\
\hline Scrub/shrub & 12 & $\mathrm{~A} / \mathrm{D}$ & 27.23 & 2.06 & 0.17 \\
\hline Cultivated crops & 6 & $\mathrm{C}$ & 27.14 & 1.20 & 0.59 \\
\hline Cultivated crops & 6 & D-SoEx & 27.05 & 1.59 & 0.23 \\
\hline \multicolumn{6}{|c|}{ Lowest 10 categories } \\
\hline Roads/runways/bare rock & 16 & $\mathrm{C}$ & 3.71 & 1.50 & 0.31 \\
\hline Roads/runways/bare rock & 16 & D-Poor & 3.90 & 2.28 & 0.31 \\
\hline Roads/runways/bare rock & 16 & A & 3.90 & 1.49 & 0.16 \\
\hline Wetlands & 15 & $\mathrm{~B} / \mathrm{D}$ & 6.67 & 2.14 & 0.17 \\
\hline Roads/runways/bare rock & 16 & $\mathrm{C} / \mathrm{D}$ & 7.03 & 2.70 & 0.26 \\
\hline Roads/runways/bare rock & 16 & D-SoEx & 7.89 & 5.23 & 0.15 \\
\hline Evergreen forest & 10 & D-Poor & 10.70 & 2.86 & 8.36 \\
\hline Mixed forest & 11 & D-Poor & 11.34 & 2.81 & 11.76 \\
\hline Deciduous forest & 9 & D-Poor & 11.99 & 4.21 & 3.07 \\
\hline Wetlands & 15 & D-Poor & 12.05 & 3.72 & 0.50 \\
\hline
\end{tabular}

(mean) value for the State is 2.62 in.; the 10th percentile is $1.49 \mathrm{in}$. and the 90 th percentile is $3.78 \mathrm{in}$. To translate these into an absolute uncertainty of the average recharge, a typical method is to take plus or minus 2 times the standard deviation of a value.

Overall, most of the modeled area has a calculated uncertainty (standard deviation) between 1.5 and 4.0 in. (fig. 20). The uncertainty of the estimated recharge rates for the most abundant land-use class:hydrologic soil group categories in the State have a wide range, from 0.81 to 6.41 in. (table 9). The amount of uncertainty generally is lower for categories with group A or B soils, which are more permeable and well drained. In these areas, the standard deviation from the Monte Carlo runs reflects the fact that few of the parameters that have a high degree of identifiability (fig. 13B) apply to these categories. Several of the categories with more poorly drained soil groups (D-Poor in particular) have much higher standard deviation from the Monte Carlo runs than the other categories, but the values are not directly proportional to the amount of identifiability of the model parameters.
The land-use class:hydrologic soil group categories with the highest average potential recharge, most of which have group A soils and vegetation with relatively shallow root zones such as blueberry barrens, scrub/shrub, pasture/hay, and cultivated crops, also have relatively small amounts of uncertainty relative to the total recharge (fig. 21). The categories with the lowest potential recharge rates, which include land uses with relatively impervious surfaces (roads/runways/ bare rock), some wetlands, and forest types with D-Poor soils, have uncertainty values that are much higher in relation to the amount of modeled potential recharge, but some of these uncertainty values are similar in absolute magnitude to the higher-recharge categories.

The standard deviation values can be used to calculate a 95-percent confidence interval around the median potential recharge value. The total 95-percent confidence range is calculated using the standard deviation $(\sigma)$ : minimum $=$ median $(2 \times \sigma)$ and maximum $=$ median $+(2 \times \sigma)$. For any area of interest, the 95-percent confidence intervals can be calculated to get an estimate of the overall possible range in the modeled 25-year average potential recharge. 


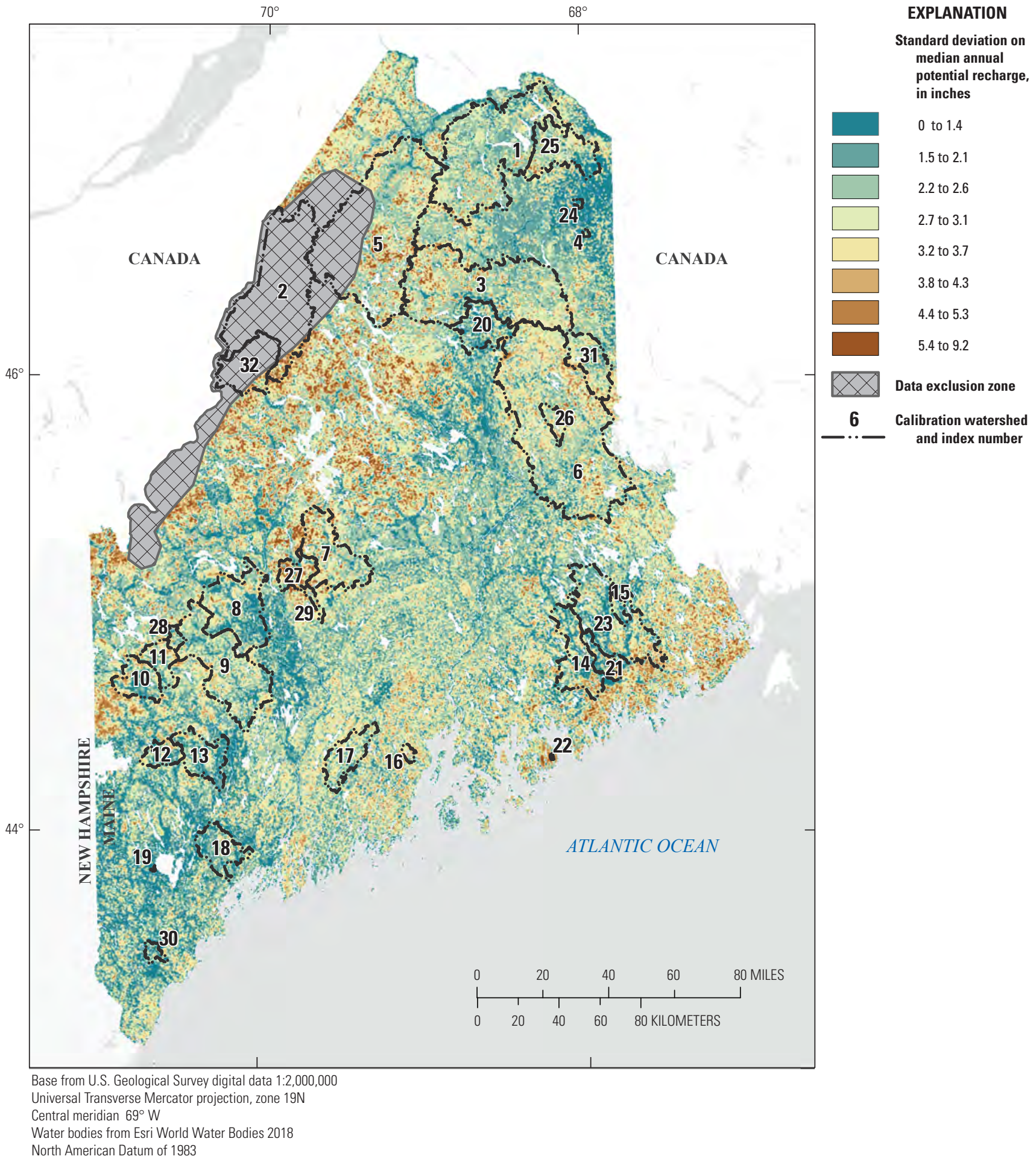

Figure 19. Calculated standard deviation on the median annual potential recharge to groundwater for Maine, 1991 to 2015. 


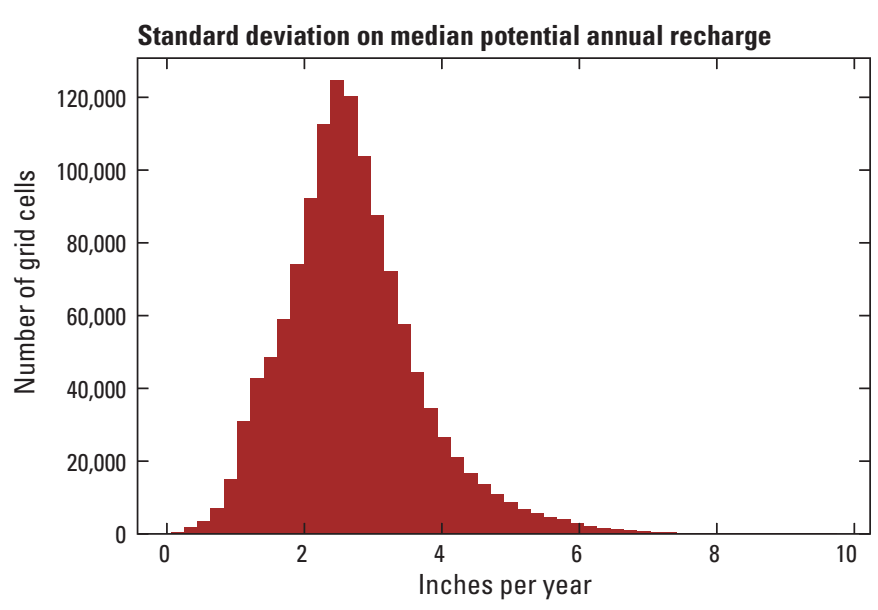

Figure 20. Distribution of the calculated standard deviation of the potential median annual recharge.

\section{Other Sources of Uncertainty}

Other factors also contribute to the overall uncertainty in the recharge estimates, but because they are nonvarying components of the model, they cannot be changed to evaluate their contribution to the total uncertainty. These include uncertainty in the DayMet climate data used in the simulation, uncertainty in the soils mapping from NRCS (including the hydrologic soil groups and AWC), and uncertainty in the landuse grid. Some of these other sources of uncertainty that are not specifically quantifiable can be discussed or evaluated in a qualitative manner.

The DayMet data (Thornton and others, 2018) are based on a model that interpolates precipitation and temperature data between climate data-collection points. Across the northwest boundary between Maine and Canada, anomalous values of annual precipitation are likely artifacts of the interpolation methods used between stations in Canada and the United States because these do not appear anywhere else in the State (fig. 8). As discussed in the "Exclusion Zone" section, an exclusion zone was set up to remove those anomalous areas from the final datasets.

Another example of underlying datasets possibly contributing to model error is that land use has changed in some areas of the State since the MELCD data were collected in 1999 and 2000. One particular land-use class, scrub/shrub, is particularly common in the northern and northwestern part of the State where logging in the 1990s produced large areas of clearcuts or patchy clearcuts, which were assigned the scrub/ shrub land-use class before trees had a chance to grow back. By the end of the model simulations in 2015, these areas would have likely grown up into young forests, which would change the ET response to precipitation. Although the land use was slowly changing over the 25 -year simulation period, which would be reflected in the observations of ET, base flow, and direct runoff, the model is not set up to have parameters that also change with time. Urbanization also increased a small amount during the 25 -year simulation time, but this landuse class covers a relatively small percentage of the overall model area.

The other source of data for the model that could contribute uncertainty is the soils data from the NRCS. The mapping of the soil units and assignments of AWC was done originally by county soil staff, and the interpretation of surficial geology and soil classes is not uniform across the State. For example, the hydrologic soil group C/D is described in USDA, NRCS (2007) as having moderately low water transmission rates and a water table less than $60 \mathrm{~cm}$ from the surface, which implies that the designation would typically apply to areas with impeded drainage such as wetlands. However, some counties assigned large areas of thin glacial till soils over bedrock in mountainous areas to the C/D hydrologic soil group even if they did not have a shallow water table, whereas in other counties the thin glacial till over bedrock in mountainous areas was assigned to the D hydrologic soil group. Therefore, areas in different parts of the State may not behave very differently (in terms of the observed values of ET, runoff, and base flow), but because the soils are assigned using different criteria the model simulates them quite differently. Another source of possible uncertainty from the NRCS is the AWC data. As discussed earlier, the assignment of the AWC is not always understandable from the point of the hydrologic soil groups (see the "Model Input Data Summary" section) or underlying soil classification, so the accuracy of this dataset is unknown, and the uncertainty contribution to the overall results would be difficult to quantify (but may be important).

\section{Comparison of Average Recharge to Previous Studies}

As noted in the introduction, there are relatively few published studies that deterministically evaluated recharge in the State for a specific location. Over the last 30 years, the USGS has published only four calibrated groundwater models for the State plus a couple of other groundwater studies that evaluated recharge for a particular study area. There have been many consulting studies (some using groundwater-flow models) done for local municipalities and other organizations, but these are generally not available to the public, and many are not well calibrated to local groundwater levels and streamflows. Using available information from the USGS studies and two consulting studies, an evaluation was done to see how well the statewide SWB model represented conditions at the local scale. The studies from the USGS included a 1983 groundwater flow model of the Little Androscoggin River valley aquifer near Norway, Maine (Morrissey, 1983); a groundwater-flow model of the Saco River valley aquifer near Fryeburg, Maine (Tepper and others, 1990); a 2011 groundwater-flow model of the Freeport Aquifer area (a buried sand and gravel aquifer and surrounding watershed; Nielsen and Locke, 2012); and a 2014 groundwater flow model of the Branch Brook and Merriland River watersheds in southern Maine (Nielsen and 
Table 9. Median and mean estimated annual potential recharge rates for the 20 most-abundant land-use class:hydrologic soil group categories in the Maine Soil-Water Balance model.

\begin{tabular}{|c|c|c|c|c|c|}
\hline Land-use class & $\begin{array}{l}\text { Hydrologic soil } \\
\text { group }\end{array}$ & $\begin{array}{l}\text { Median potential } \\
\text { recharge (in.) }\end{array}$ & $\begin{array}{l}\text { Mean potential } \\
\text { recharge (in.) }\end{array}$ & $\begin{array}{l}\text { Percentage of land } \\
\text { area in model }\end{array}$ & $\begin{array}{l}\text { Standard deviation on } \\
\text { median recharge (in.) }\end{array}$ \\
\hline Mixed forest & D-Poor & 11.34 & 12.73 & 11.76 & 2.81 \\
\hline Evergreen forest & D-Poor & 10.7 & 12.02 & 8.36 & 2.86 \\
\hline Mixed forest & $\mathrm{C} / \mathrm{D}$ & 13.18 & 15.22 & 7.31 & 2.45 \\
\hline Mixed forest & $\mathrm{C}$ & 18.47 & 17.59 & 6.03 & 2.35 \\
\hline Mixed forest & D-SoEx & 17.67 & 17.35 & 4.68 & 3.07 \\
\hline Scrub/shrub & D-Poor & 13.61 & 15.75 & 4.61 & 6.41 \\
\hline Deciduous forest & $\mathrm{C} / \mathrm{D}$ & 14.21 & 16.92 & 3.83 & 3.43 \\
\hline Deciduous forest & $\mathrm{C}$ & 20.53 & 19.99 & 3.40 & 1.68 \\
\hline Evergreen forest & $\mathrm{C} / \mathrm{D}$ & 13.18 & 13.67 & 3.07 & 2.32 \\
\hline Deciduous forest & D-Poor & 11.99 & 15.39 & 3.07 & 4.21 \\
\hline Deciduous forest & D-SoEx & 19.32 & 19.70 & 2.69 & 3.36 \\
\hline Mixed forest & $\mathrm{A}$ & 23.55 & 22.42 & 2.56 & 1.10 \\
\hline Evergreen forest & D-SoEx & 17.45 & 17.55 & 2.54 & 3.50 \\
\hline Evergreen forest & $\mathrm{C}$ & 16.44 & 16.95 & 2.49 & 1.86 \\
\hline Wetland forest & D-Poor & 12.44 & 13.29 & 1.87 & 3.88 \\
\hline Scrub/shrub & $\mathrm{C} / \mathrm{D}$ & 20.97 & 22.21 & 1.85 & 2.34 \\
\hline Evergreen forest & $\mathrm{A}$ & 22.55 & 21.79 & 1.62 & 1.16 \\
\hline Wetlands from soils & $\mathrm{A} / \mathrm{D}$ & 16.11 & 18.30 & 1.50 & 3.30 \\
\hline Scrub/shrub & $\mathrm{C}$ & 23.11 & 23.53 & 1.41 & 1.87 \\
\hline Mixed forest & $\mathrm{B}$ & 20.05 & 19.04 & 1.33 & 0.81 \\
\hline
\end{tabular}

Locke, 2015). The consulting reports of modeling efforts with published recharge rates include a 1986 study of the islands in Casco Bay (Robert G. Gerber, Inc., 1986), and a groundwater model prepared for the town of Bar Harbor, Maine in 2007 (Robinson and Gerber, 2007). The evaluation of each of the studies involved calculating the SWB average annual potential recharge over a zone of each modeled area with reported, calibrated annual recharge and comparing it with the published study. For each of the areas tested, the 95-percent confidence interval for the Maine SWB estimate also was calculated.

The comparisons of previous studies and the Maine SWB estimates are presented here based on the type of geology/soils in the area evaluated, or the hydrogeologic setting. The principal hydrogeologic settings evaluated include outwash sand and gravel deposits, other sandy deposits and till, silt and clay deposits, and till or other thin deposits over bedrock. Some of the studies cited above only included one hydrogeologic setting in the recharge calculations, and others have several.

Because most of the previous studies in the State have focused on groundwater availability in areas of known productive sand and gravel aquifers, there are five different areas with outwash sand and gravel deposits to compare with the SWB potential average recharge (fig. 22). The SWB potential recharge estimates compare favorably with all the outwash zones, even though some (the Little Andsroscoggin and Saco River valley aquifers) were studied in the early to mid-1980s. Two of the three sand and till deposit areas also compare very well between the SWB potential recharge and the site-specific model areas (the second of two Freeport aquifer zones, and one of three zones in the Bar Harbor model). However, as the amount of reported recharge goes down, the ability of the SWB modeled recharge to reproduce those values is decreased. None of the silt and clay zones or the till over bedrock zones is estimated very well in the SWB model, in which case it is modeling the recharge too high. The reasons for the SWB model's lack of agreement with the groundwater-flowmodeled values in these areas differs by hydrogeologic setting.

Three of the areas with previously published low modeled recharge values but higher SWB estimates are in areas with relatively thick surficial deposits of low permeability where the water table is above the underlying bedrock (a till zone in Bar Harbor and the silt and clay zones in Freeport and the Branch Brook area). The soils that are mapped over the silt and clay zones in these study areas are a mix of hydrologic soil groups $\mathrm{A} / \mathrm{D}, \mathrm{B} / \mathrm{D}$, and $\mathrm{D}-\mathrm{Poor}$, and wetland forest or deciduous and mixed forest land-use classes cover most of these areas. Wetlands are often represented as soil group A/D or B/D, which are peaty soils or sandy soils overlying the 


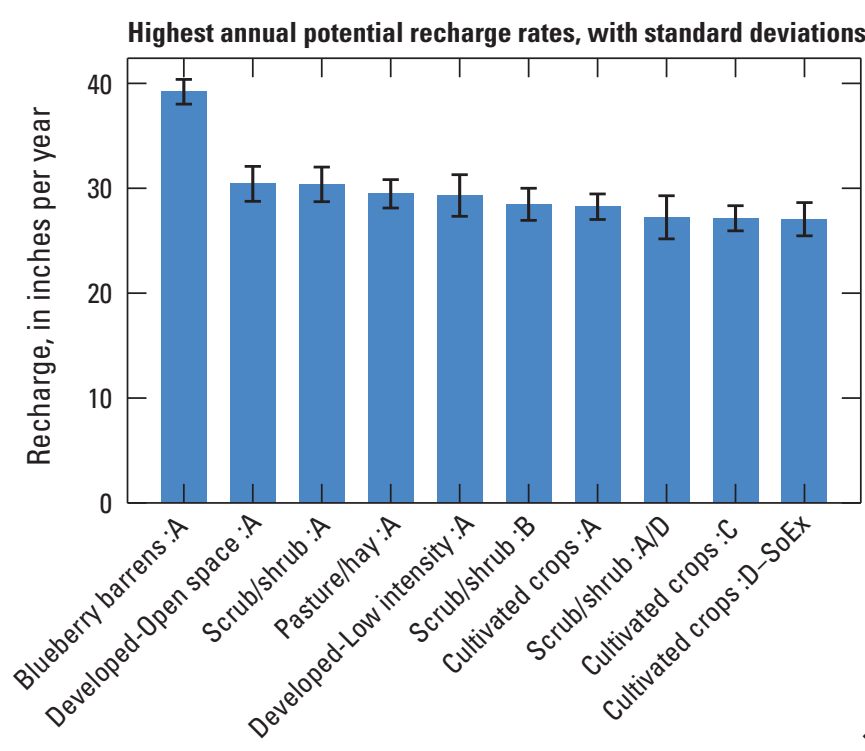

Land use: soil category

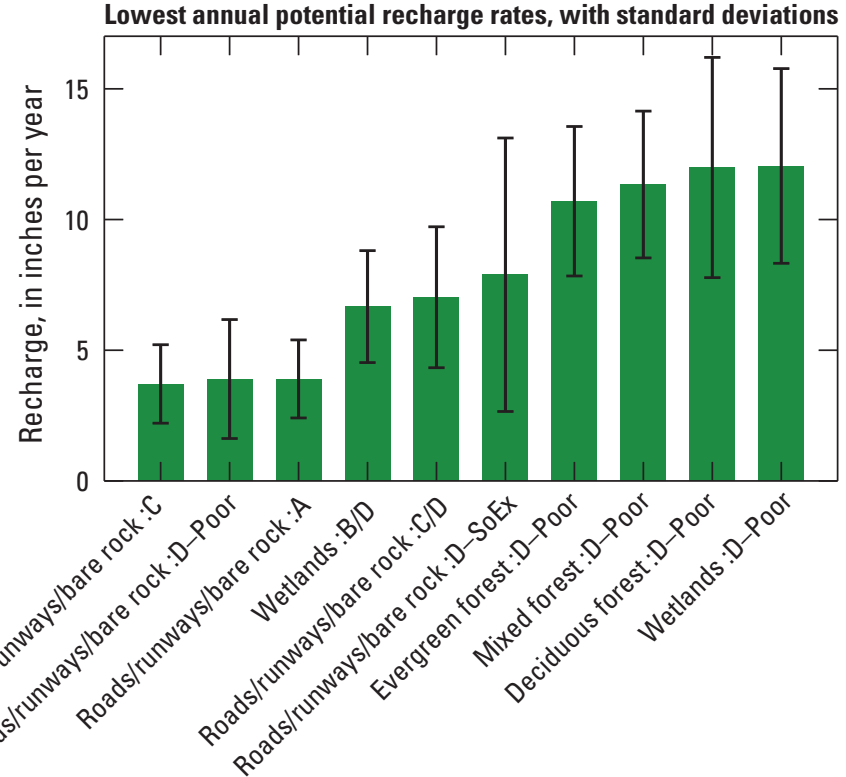

Land use: soil category

EXPLANATION

Soil-Water-Balance median annual potential recharge with whiskers showing plus or minus one standard deviation

Figure 21. Highest and lowest median annual potential recharge by land-use class:hydrologic soil group category, with standard deviations.

silt and clay deposit. The SWB modeled potential recharge depends very much on what the mapped AWC is for any particular model cell. For model cells in these silt/clay areas where the available water capacity is over $3 \mathrm{in} / \mathrm{ft}$ (as would be expected for a peaty soil, or for a sandy soil that could not drain because of the underlying silt and clay), the potential recharge is closer to what would be expected (7 in/yr). However, the available water capacity is often a lower value in these model cells (less than $1 \mathrm{in} / \mathrm{ft}$, typical of a coarse sand that is well drained), resulting in a SWB potential recharge that is much higher (often around $17 \mathrm{in} / \mathrm{yr}$ ).

The remaining hydrogeologic setting to be discussed here is the fairly common situation where there is a thin soil layer (often till) over a shallow bedrock unit. Three previous studies have these settings: part of the Branch Brook model area, part of the Bar Harbor model area, and the 1980s study of islands in Casco Bay. As noted in the introduction in this report, the potential recharge modeled by SWB only takes into consideration the soil characteristics at the surface and does not have any way to simulate what may happen to infiltration below the root zone that encounters a relatively impermeable bedrock zone. In each of the studies evaluated, the recharge to bedrock is reported to be $5 \mathrm{in} / \mathrm{yr}$ or less, but the SWB potential recharge is estimated at $15 \mathrm{in} / \mathrm{yr}$ ( \pm 4 to $8 \mathrm{in} / \mathrm{yr}$ ). The $\mathrm{SWB}$ model does predict low potential infiltration when the surface is represented as a relatively impervious surface (roads/runways/bare rock) but not where there is a mapped soil layer above the bedrock.

The conclusions to be drawn from these comparisons are that the Maine SWB model performs well in representing an accurate potential recharge under circumstances where the surficial mapped soils extend below the surface to the watertable aquifer and where the AWC data are in an appropriate range for the hydrologic soil group. The areas where the SWB model has difficulty in representing the potential recharge accurately are where there is a shallow impermeable layer in the unsaturated zone below the mapped soil unit that impeded vertical movement of potential recharge to the aquifer, such as a bedrock surface, or where the mapped AWC is not appropriate for the hydrologic soil group.

\section{Estimated 25-Year Potential Recharge Statistics and Ranges for Calibration Watersheds}

The SWB estimated median annual potential recharge for the watersheds used in the calibration of the model ranges from over $21 \mathrm{in} / \mathrm{yr}$ in several calibration watersheds (4 [Williams Brook], 14 [Narraguagus River], 18 [Royal River], 19 [Stony Brook], 21 [Pleasant River], and 22 [Otter Creek]) to less than $16.5 \mathrm{in} / \mathrm{yr}$ in the calibration watersheds 3 

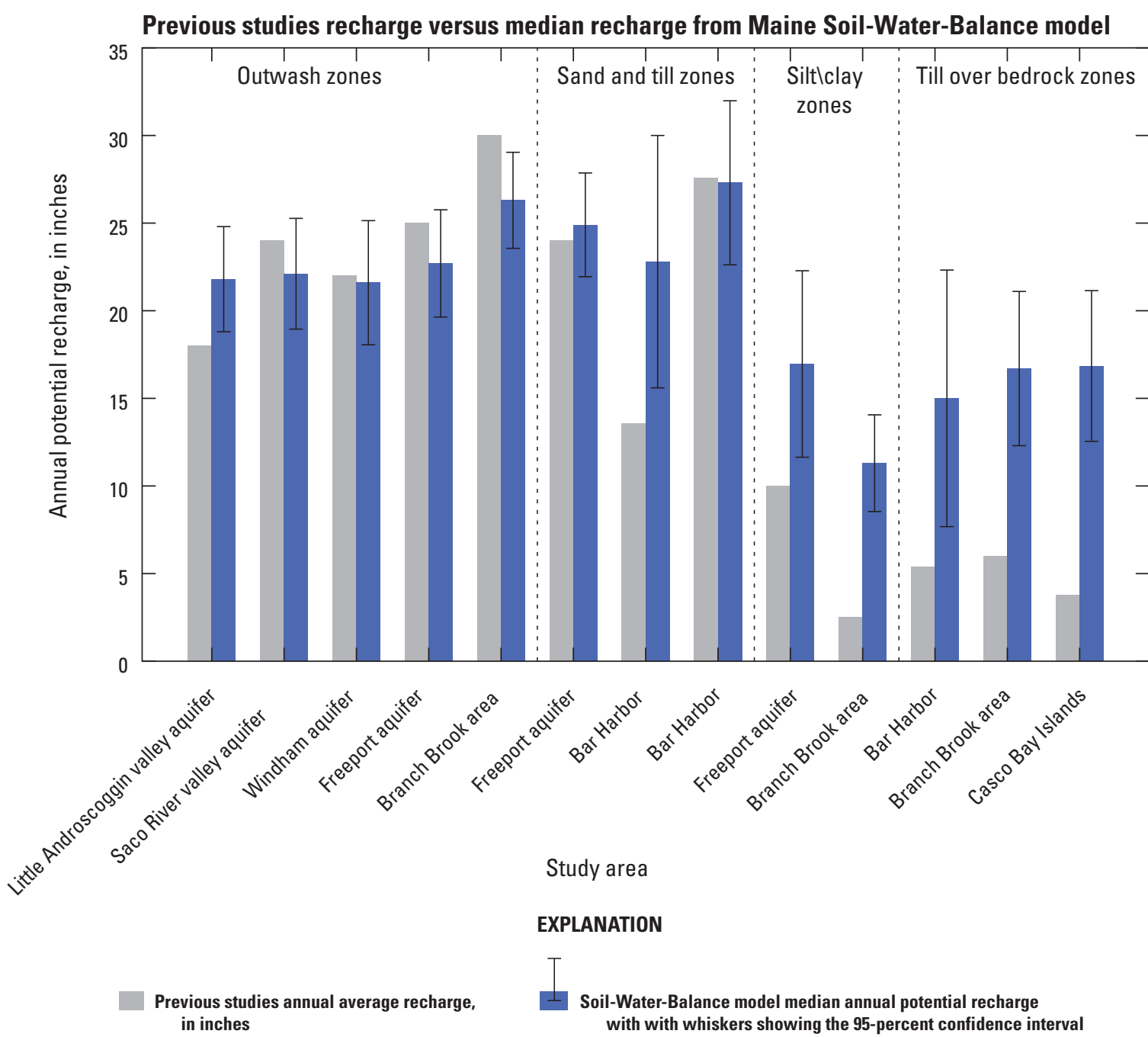

Figure 22. A comparison of previously published annual average recharge values in a selection of study areas in Maine, and corresponding median potential annual recharge from the Maine Soil-Water-Balance model, with 95-percent confidence intervals calculated from the standard deviation grid.

(Aroostook River), 5 (Allagash River), 6 (Mattawamkeag River), 7 (Piscataquis River), 20 (Seboeis River), and 25 (Little Madawaska River; table 10). Watersheds with significant amounts of sand and gravel aquifers (Dudley and Nielsen, 2011), such as 21 (Pleasant River), 14 (Narraguagus River), 18 (Royal River), and 19 (Stony Brook), have relatively high estimated total potential recharge. Several of the watersheds with lower amounts of annual potential recharge are in areas of the State receiving low amounts of total precipitation (see fig. 8).

The 95-percent confidence intervals are greatest for the calibration watersheds with highest standard deviation values (table 10): 22 (Otter Creek), 27 (Austin Stream), 16 (Ducktrap River), 29 (East Branch Wesserunsett Stream), and 7 (Piscataquis River). Some watersheds had relatively stable estimates regardless of the suite of parameters used in the Monte Carlo exercise and therefore will have narrower 95-percent confidence intervals: 24 (Hardwood Brook), 19 (Stony Brook), 4 (Williams Brook), 30 (Kennebunk River), and 13 (Nezinscot River).

The values shown in table 10 for the minimum and maximum annual recharge should be viewed as extreme valuesthe minimum and maximum value for each cell in the model is computed over the 25 -year simulation. In larger calibration watersheds it is unlikely that the minimum or maximum values would occur for the whole watershed in a given year.

\section{Uses and Limitations}

The uses for which the grids are appropriately described and an example of such a use are included in this section. The discussion of limitations and uses of the 25-year annual potential recharge grids include geographic limitations and application limitations. 
Table 10. Annual potential recharge statistics calculated for Soil-Water-Balance model calibration watersheds.

[in., inch; --, no data]

\begin{tabular}{|c|c|c|c|c|c|c|}
\hline \multirow{2}{*}{$\begin{array}{c}\text { Calibration } \\
\text { watershed } \\
\text { index number }\end{array}$} & \multirow[b]{2}{*}{ Calibration watershed name } & \multicolumn{5}{|c|}{ Potential recharge, 1991-2015 (in.) } \\
\hline & & $\begin{array}{l}\text { Mean } \\
\text { annual }\end{array}$ & $\begin{array}{c}\text { Median } \\
\text { annual }\end{array}$ & $\begin{array}{l}\text { Standard deviation } \\
\text { around the median } \\
\text { annual value }\end{array}$ & $\begin{array}{c}\text { Minimum } \\
\text { annual }\end{array}$ & $\begin{array}{c}\text { Maximum } \\
\text { annual }\end{array}$ \\
\hline 1 & Fish River & 14.76 & 14.49 & 2.55 & 8.51 & 21.93 \\
\hline 2 & St. John River & -- & -- & -- & -- & -- \\
\hline 3 & Aroostook River & 13.97 & 13.73 & 2.79 & 7.40 & 22.18 \\
\hline 4 & Williams Brook & 20.76 & 21.11 & 1.98 & 11.85 & 30.10 \\
\hline 5 & Allagash River & 13.44 & 12.57 & 2.96 & 7.65 & 21.42 \\
\hline 6 & Mattawamkeag River & 15.78 & 15.76 & 2.82 & 7.34 & 25.41 \\
\hline 7 & Piscataquis River & 16.67 & 16.38 & 3.00 & 9.09 & 24.65 \\
\hline 8 & Carrabassett River & 18.50 & 17.61 & 2.29 & 10.59 & 27.05 \\
\hline 9 & Sandy River-Mercer & 17.38 & 16.76 & 2.54 & 10.42 & 24.94 \\
\hline 10 & Ellis River & 19.92 & 19.44 & 2.52 & 12.41 & 28.57 \\
\hline 11 & Swift River & 19.49 & 19.09 & 2.77 & 12.51 & 27.38 \\
\hline 12 & Little Androscoggin River & 20.95 & 19.81 & 2.36 & 13.10 & 30.24 \\
\hline 13 & Nezinscot River & 20.68 & 19.68 & 2.20 & 13.06 & 29.27 \\
\hline 14 & Narraguagus River & 22.12 & 22.14 & 2.51 & 9.74 & 32.22 \\
\hline 15 & Old Stream & 20.68 & 20.50 & 2.36 & 9.63 & 30.79 \\
\hline 16 & Ducktrap River & 20.01 & 19.60 & 3.04 & 10.38 & 28.37 \\
\hline 17 & Sheepscot River & 20.14 & 19.91 & 2.61 & 10.08 & 28.84 \\
\hline 18 & Royal River & 22.18 & 21.10 & 2.12 & 13.89 & 32.27 \\
\hline 19 & Stony Brook & 24.54 & 22.99 & 1.55 & 14.62 & 38.36 \\
\hline 20 & Seboeis River & 16.43 & 15.89 & 2.15 & 8.07 & 29.75 \\
\hline 21 & Pleasant River & 25.43 & 25.54 & 2.31 & 11.54 & 36.11 \\
\hline 22 & Otter Creek & 28.89 & 28.85 & 5.60 & 18.51 & 38.10 \\
\hline 23 & Machias River & 20.64 & 20.45 & 2.48 & 9.47 & 30.77 \\
\hline 24 & Hardwood Brook & 20.82 & 20.30 & 1.57 & 12.18 & 31.87 \\
\hline 25 & Little Madawaska River & 15.11 & 15.14 & 2.51 & 9.06 & 21.75 \\
\hline 26 & Wytopitlock Stream & 16.29 & 16.21 & 2.92 & 7.61 & 27.20 \\
\hline 27 & Austin Stream & 18.87 & 18.71 & 3.59 & 11.17 & 27.28 \\
\hline 28 & Sandy River-Madrid & 18.00 & 17.66 & 2.65 & 10.92 & 25.81 \\
\hline 29 & East Branch Wesserunsett Stream & 20.10 & 20.04 & 3.03 & 11.70 & 28.48 \\
\hline 30 & Kennebunk River & 23.01 & 21.01 & 2.02 & 15.08 & 36.69 \\
\hline 31 & Meduxnekeag River & 17.33 & 17.41 & 2.83 & 8.23 & 25.94 \\
\hline 32 & North Branch Penobscot River & -- & -- & -- & -- & -- \\
\hline
\end{tabular}


Table 11. Example of calculations for a watershed using the annual potential recharge grids in Maine.

\begin{tabular}{|c|c|c|}
\hline Calculation or result desired & How calculated & Example results \\
\hline Watershed area & $\begin{array}{l}\text { Calculate using StreamStats (Lombard, 2015) or geographic } \\
\text { information system software }\end{array}$ & 12.4 square miles \\
\hline $\begin{array}{l}\text { Standard deviation of potential } \\
\text { recharge for the watershed }\end{array}$ & $\begin{array}{l}\text { Calculate the areal average of the standard deviation grid } \\
\text { using geographic information system software }\end{array}$ & 2.1 inches per year \\
\hline $\begin{array}{l}\text { 95-percent confidence interval } \\
\text { on the mean potential } \\
\text { recharge }\end{array}$ & $\begin{array}{l}\text { Using the method provided on p. } 37 \text { and p. } 44 \text {, calculate the } \\
\text { minimum and maximum for the confidence interval. }\end{array}$ & $\begin{array}{l}\text { The confidence range (or interval) would } \\
\text { be plus or minus } 4.2 \text { inches per year, or } \\
\text { from } 12.4 \text { to } 21.0 \text { inches per year. }\end{array}$ \\
\hline $\begin{array}{l}\text { 25-year minimum potential } \\
\text { recharge }\end{array}$ & $\begin{array}{l}\text { Calculate the areal average of the } 25 \text {-year minimum potential } \\
\text { recharge grid for the watershed using geographic informa- } \\
\text { tion system software. }\end{array}$ & 8.1 inches per year \\
\hline
\end{tabular}

\section{Appropriate Uses and Example Use Application}

The grids of potential annual recharge for Maine are intended to be used to provide first-cut estimates of recharge for geographic areas no smaller than the smallest watersheds used in the calibration of the model —or about 1.5 square miles. It is recommended that the grids be used to calculate an area-wide average potential recharge for any given area of study (as compared to point-specific potential recharge), and an uncertainty around the mean should be calculated from the standard deviation grid at the same time.

One potential use of the Maine SWB potential annual recharge grids would be to create an initial estimate of recharge for an area for which one might want to calculate an overall water budget, such as for a watershed. The suggested application of the data would include the following steps. First, define the watershed boundaries for the study using GIS software or using the Maine StreamStats application (Lombard, 2015; https://streamstats.usgs.gov/ss/). A shapefile of the watershed can be downloaded from StreamStats. Using the datasets from the data release accompanying this report (Nielsen and Westenbroek, 2019), calculate the spatial average (or mean) value for the watershed for each of the potential recharge layers - mean annual, median annual, 25-year minimum, and 25-year maximum. Then, calculate the spatial mean value for the standard deviation layer. Finally, calculate the 95-percent confidence interval on the mean and median using the standard deviation grid: the 95-percent confidence range is calculated using the standard deviation $(\sigma)$ : minimum $=$ median $-(2 \times \sigma)$ and maximum $=$ median $+(2 \times \sigma)$.

For an example watershed located somewhere in Maine that is 12.4 square miles in area, a list of the results for calculating the mean annual potential recharge could produce the results as listed in table 11. The standard deviation grid is intended for use with the 25 -year mean and median potential recharge grids but not for the 25 -year minimum or maximum grids.

\section{Limitations to the Availability and Use of the Potential Recharge Grids}

Areas of no data for the State recharge grids include the White Mountain National Forest and the former Brunswick Naval Air Station, for which areas soils data were not available. In addition, the anomalous DayMet precipitation data (Thornton and others, 2018) were screened out of the final analysis with an exclusion zone in northwestern Maine along the Canadian border (figs. 15-19).

Refer to the "Model Limitations and Assumptions" section for a discussion of the potential use and interpretation limitations of the modeled output. In addition, the mapping of the AWC values does affect the ability of the Maine SWB model to accurately represent the average potential recharge. Users are encouraged to verify that the AWC is in an expected range for the hydrologic soil groups in their area of interest. The AWC and hydrologic soil groups data for this model can be found in the USGS model archive for this model at (https://doi.org/10.5066/P9GRP7DH; Nielsen, 2019).

\section{Summary and Conclusions}

To estimate average annual recharge to groundwater in Maine, the U.S. Geological Survey Soil-Water-Balance (SWB) model was used to simulate potential annual recharge across the whole State from 1991 to 2015, in cooperation with the Maine Geological Survey. The 25-year simulation results are presented as 25-year average (mean and median), minimum, and maximum potential recharge grids. Compared to previously published large-scale SWB models, the Maine SWB model presents several innovations in model calibration and uncertainty analysis. This is the first published SWB model to incorporate a rigorous parameter estimation calibration that accounts for all three of the main components of the water budged: recharge, runoff, and evapotranspiration (ET), 
using observations covering 32 calibration watersheds in the State. SWB's implementation of the Food and Agriculture Organization of the United Nations Drainage and Irrigation Paper 56 (FAO56) ET method was used, which provides more control over the treatment of ET in forests than the standard method. A new approach to displaying uncertainty in the SWB output was applied to the Maine SWB model, using null-space Monte Carlo analysis and several hundred alternate realizations of the model input parameters to derive a standard deviation grid of the final 25 -year annual average potential recharge grid.

SWB calculates excess soil moisture (potential recharge) by dividing up input to the hydrologic system being modeled (precipitation or snowmelt) into fractions of direct runoff, plant interception, soil infiltration, actual ET, soil moisture storage, rejected recharge, and infiltration of excess soil moisture to the water table (potential recharge). The inputs required for running the Maine SWB model consists of (a) grids describing the study domain (land use, hydrologic soil groups, and soil available water capacity [AWC]); (b) grids of daily climate data; (c) lookup table values for the water balance calculations with runoff curve numbers, maximum potential infiltration rates, rooting depths, and information on how interception is handled for each combination of land-use class and hydrologic soil group; and (d) lookup table values for the implementation of the FAO56 ET calculations (plant growth settings and bare soil evaporation settings).

Land-use data for the Maine SWB model was based on the Maine Land Cover Dataset, which was compressed to 19 land-use classes for this study. The other two data inputs for SWB (hydrologic soil groups and AWC) were produced for this study using gridded soil survey data from 2016 (the Natural Resources Conservation Service [NRCS] gridded Soil Survey Geographic Database [gSSURGO] data). The hydrologic soil groups are used in SWB alongside land-use classes to classify the landscape into combinations of land use/vegetation and soil texture that should, in theory, transmit water similarly through the rooting zone and unsaturated zone to the water table under the same climatic conditions. DayMet (version 3) daily climate data from the Oak Ridge National Laboratory were the source of the daily minimum and maximum temperature and daily precipitation and have a spatial resolution of 1 kilometer .

The Parameter ESTimation (PEST) software suite was used for the calibration. The model was calibrated to optimize the output to fit 902 weighted observations of annual recharge, runoff, and ET from 32 unregulated watersheds in Maine for 2001 to 2012. The annual recharge and runoff observations were obtained using an average of nine base flow-separation techniques for the hydrograph at the streamgage for each watershed. The annual ET observations were obtained by calculating the average value of ET from national gridded ET datasets for the same watersheds. Over 500 parameters were adjusted at some point during the calibration, which were primarily values from the two SWB lookup tables: runoff curve numbers, maximum infiltration rates, rooting depths, plant
ET factors, and bare soil ET factors. PEST's use of highly parameterized inversion allows for the use of hundreds of model parameters, while not introducing problems of parameter insensitivity and correlation. Tihkonov regularization was used during the PEST runs, which prevents an "overfit" model when there are many parameters. All model runs were controlled and organized using the HTCondor computer cluster at the T.C. Chamberlin computing center at the Middleton, Wisconsin USGS office.

The overall mean model error (average of all residuals) for the calibrated SWB model was 0.39 inches (in.). The mean of the absolute value of the residuals, or the mean absolute error, was $2.32 \mathrm{in}$. The root mean squared error for the calibrated model overall is $3.14 \mathrm{in}$. The $r^{2}$ value for the simulated versus observed values for the Maine SWB model is 0.76. The Nash-Sutcliffe efficiency for the Maine SWB model is 0.75 . The simulated model results line up closely to the $1: 1$ line, indicating a relatively accurate model where the residuals do not deviate significantly from the line in one direction or another, and statistical tests show that the residuals are normally distributed.

The model was calibrated at a 500-meter $(\mathrm{m})$ grid-cell size for 12 years to make the run times for the model reasonable enough to allow for thousands of model runs per calibration run. Once model parameters were calibrated, the model was run for the final time for a 25 -year period using a $250-\mathrm{m}$ grid size.

Using the best-fit set of parameters from the calibration runs, the Maine SWB model was run for 25 years, from 1991 to 2015 , using a $250-\mathrm{m}$ grid-cell size. The 25 annual grids were used to calculate the 25 -year mean annual potential recharge, median annual potential recharge and the minimum and maximum potential recharge for the 25 -year simulation. Based on anomalous precipitation data in northwestern Maine, an "exclusion zone" was created and used to screen out some of the area along the Canadian border from the final analysis because the calculated potential recharge values in this area are not considered representative of actual conditions. As expected, there is wide variability in the simulated 25-year median potential recharge across the State. This variability closely follows patterns of precipitation, with additional variability contributed by the patchwork nature of the intersection of land-use class and hydrologic soil groups across the State. Overall, the 25-year median potential recharge across the State is $7.98 \mathrm{in}$., ranging from a low of about $5 \mathrm{in}$. to as much as $38.7 \mathrm{in}$. The statewide range in the 25 -year minimum values is very compressed-from just over 2 in. to just over 20 in.; almost everywhere in the State experienced a drought-year low of less than $10 \mathrm{in.} \mathrm{of} \mathrm{potential} \mathrm{recharge} \mathrm{per} \mathrm{year} \mathrm{sometime}$ during the 25-year simulation period. The statewide range in the 25 -year maximum potential recharge is much more variable (between 15 and 48 inches per year).

To quantify the uncertainty in the 25 -year average potential recharge that results from uncertainty in the best-fit values of each of the 500 or so parameters used in the calibration, a formal uncertainty calculation was done. Portraying 
the uncertainty in the results of the SWB modeling exercise is difficult because the study result is not a prediction of a change in some measurable volume or measurement of interest but rather a surface across the entire State. Techniques of uncertainty analyses using linear-based first-order, second-moment methods to analyze model response to specific conditions at a particular time and place are not readily applicable to this kind of output. Therefore, the null-space Monte Carlo analysis was used, in which several hundred alternate parameter sets were generated (that could theoretically satisfy the calibration criteria) and run through the SWB model. After running hundreds of alternate models, a grid of the standard deviation of the modeled potential recharge was calculated. This is the first SWB model to use this technique for uncertainty analysis.

This standard deviation grid provides a quantitative measure of the uncertainty in the Maine potential recharge grids that is a result of uncertainties in the model parameter values. The average (mean) standard deviation for the State is 2.6 in.; the 10th percentile is 1.5 and the 90 th percentile is 3.8 . To translate these into a 95-percent confidence interval of the average recharge for a given area, a typical method is to take plus or minus two times the standard deviation of the average potential recharge for the same area.

Other factors also contribute to the overall uncertainty in the recharge estimates, but their values cannot be changed to evaluate their contribution to the total uncertainty. These include: uncertainty in the DayMet climate data used in the simulation, uncertainty in the soils mapping from NRCS (including the hydrologic soil groups and AWC), and uncertainty in the land-use grid.

The 25-year average potential recharge grids were compared to recharge evaluated through groundwater flow models or other methods in four hydrogeologic settings at six study areas in the State. Several zones in each study area were checked - the average potential recharge and the 95-percent confidence interval in each zone were calculated and compared to the published value. In general, the Maine SWB model reproduced the published values for outwash sand and gravel aquifers better than some other settings. A key factor in the ability of the SWB model to reproduce the earlier study results was whether the AWC data as provided in the gSSURGO data were an appropriate match for the soil hydrologic group. The Maine SWB model does a good job in representing an accurate potential recharge under circumstances where the surficial mapped soils extend below the surface to the water-table aquifer and where the AWC data are in an appropriate range for the hydrologic soil group. One setting where the SWB model has difficulty in representing the potential recharge accurately is where there is a shallow impermeable layer in the unsaturated zone below the mapped soil unit that impeded vertical movement of potential recharge to the aquifer, such as a bedrock surface. Another hydrogeologic setting that was challenging for the model was where a silt and clay layer was below a shallow soil unit that did not have AWC data that were appropriate for the hydrologic soil group. In these cases, typically the AWC data were very low, not accounting for the impedance of water flow provided by the underlying soil.

The final 25-year annual potential recharge grids for the State are released along with this report (https://doi.org/ 10.5066/P9052ULY). The grids of potential annual recharge for Maine are intended to be used to provide first-cut estimates of recharge for geographic areas no smaller than the smallest watersheds used in the calibration of the model-or about 1.5 square miles. It is recommended that the grids are used to calculate an areal average recharge for any given area of study, and an uncertainty around the mean should be calculated from the standard deviation grid at the same time. The user of these data also should familiarize themselves with the model limitations and assumptions are described earlier in the report. The model archive (https://doi.org/10.5066/P9GRP7DH) documents all the model construction and other model information.

\section{Acknowledgments}

Randy Hunt and Mike Fienen provided assistance in helping to guide the parameter estimation, Monte Carlo analysis and uncertainty work, and especially in making the T.C. Chamberlin computing center available for the parallel processing runs using the HTCondor computer cluster. Luke Sturtevant of the New England Water Science Center assisted in some of the initial data preparation steps. Andrew Leaf provided advice and assistance on some of the python coding tasks.

\section{References Cited}

\author{
Allen, R.G., Pereira, L.S., Raes, D., and Smith, M., 1998, \\ Crop evapotranspiration-Guidelines for computing \\ crop water requirements: Rome, Food and Agriculture \\ Organization of the United Nations, Irrigation and Drainage \\ Paper 56, 174 p. [Also available at http://www.fao.org/3/ \\ X0490E/x0490e00.htm\#Contents.]
}

Anderson, M.P., Woessner, W.W., and Hunt, R.J., 2015, Applied groundwater modeling - Simulation of flow and advective transport 2nd ed. Elsevier Press, 564 p. [Also available at https://doi.org/10.1016/C2009-0-21563-7.]

Barlow, P.M., Cunningham, W.L., Zhai, T., and Gray, M., 2015, U.S. Geological Survey groundwater toolbox, a graphical and mapping interface for analysis of hydrologic data (version 1.0) - User guide for estimation of base flow, runoff, and groundwater recharge from streamflow data: U.S. Geological Survey Techniques and Methods, book 3, chap. B10, 27 p., accessed October 2017 at https://doi.org/ $10.3133 / \mathrm{tm} 3 \mathrm{~B} 10$. 
Chow, V.T., Maidment, D.R., and Mays, L.W., 1988, Applied hydrology: New York, McGraw-Hill, Inc., 572 p.

Cronshey, R., McCuen, R.H., Miller, N., Rawls, W., Robbins, S., and Woodward, D., 1986, Urban hydrology for small watersheds (2d ed.): Washington, D.C., U.S. Department of Agriculture, Soil Conservation Service, Conservation Engineering Division, Technical Release 55, 164 p.

Ditzler, C., Scheffe, K., and Monger, H.C., eds., 2017, Soil survey manual: Washington, D.C., U.S. Government Printing Office, U.S. Department of Agriculture, Handbook 18, 315 p., accessed November 2018 at https://www.nrcs.usda.gov/wps/portal/nres/main/soils/ref/.

Doherty, J.E., 2004, PEST-Model-independent parameter estimation user manual 5th ed.: Brisbane, Australia, Watermark Numerical Computing. [Also available at https://www.nrc.gov/docs/ML0923/ML092360221.pdf.]

Doherty, J.E., and Hunt, R.J., 2009, Two statistics for evaluating parameter identifiability and error reduction: Journal of Hydrology (Amsterdam), v. 366, no. 1-4, p. 119-127. [Also available at https://doi.org/10.1016/j.jhydrol.2008.12.018.]

Doherty, J.E., and Hunt, R.J., 2010, Approaches to highly parameterized inversion-A guide to using PEST for groundwater-model calibration: U.S. Geological Survey Scientific Investigations Report 2010-5169, 59 p. [Also available at https://doi.org/10.3133/sir20105169.]

Dudley, R.W., and Nielsen, M.G., 2011, Simulation of streamflow in the Pleasant, Narraguagus, Sheepscot, and Royal Rivers, Maine, using watershed models: U.S. Geological Survey Scientific Investigations Report 2010-5221, 31 p., accessed January 2017 at https://pubs.usgs.gov/sir/ 2010/5221/.

Feinstein, D.T., Hunt, R.J., and Reeves, H.W., 2010, Regional groundwater-flow model of the Lake Michigan Basin in support of Great Lakes Basin water availability and use studies: U.S. Geological Survey Scientific Investigations Report 2010-5109, 379 p. [Also available at https://doi.org/ 10.3133/sir20105109.]

Friesz, P.J., and Stone, J.R., 2014, Areas contributing recharge to production wells and effects of climate change on the groundwater system in the Chipuxet River and Chickasheen Brook Basins, Rhode Island: U.S. Geological Survey Scientific Investigations Report 2014-5216, 56 p., 1 pl., accessed June 2015 at https://doi.org/10.3133/sir20145216.

Gerber, R.G., and Hebson, C.S., 1996, Ground water recharge rates for Maine soils and bedrock, in Loiselle, M., Weddle, T.K., and White, C., eds., 1996, Selected papers on the hydrogeology of Maine: Augusta, Maine, Geological Society of Maine, Bulletin 4, p. 23-52.
Healy, R.W., 2010, Estimating groundwater recharge: Cambridge University Press, 245 p. [Also available at https://doi.org/10.1017/CBO9780511780745.]

Helsel, D.R., and Hirsch, R.M., 1992, Statistical methods in water resources-Studies in Environmental Science, v. 49: New York, Elsevier, 522 p.

Hill, M.C., and Tiedeman, C.R., 2007, Effective groundwater model calibration with analysis of data, sensitivities, predictions and uncertainty: Hoboken, N.J., John Wiley \& Sons, 455 p. https://doi.org/10.1002/0470041080.

Hunt, R.J., Prudic, D.E., Walker, J.F., and Anderson, M.P., 2008, Importance of unsaturated zone flow for simulating recharge in a humid climate: Ground Water, v. 46, no. 4, p. 551-560. [Also available at https://doi.org/10.1111/ j.1745-6584.2007.00427.x.]

Kim, H., 2017, Estimating evapotranspiration using the complementary relationship and the Budyko framework: Logan, Utah, Utah State University PhD Thesis, 144 p.

Lombard, P.J., 2015, Maine StreamStats - A water-resources web application: U.S. Geological Survey Fact Sheet 2015-3014, 2 p., accessed June 2016 at https://doi.org/ $10.3133 /$ fs 20153014 .

Maine Office of Geographic Information Systems, 2006, MELCD: Augusta, Maine Office of Geographic Information Systems, land cover map, accessed February 20, 2015, at https://www.maine.gov/megis/catalog/metadata/melcd.html.

Masterson, J.P., Pope, J.P., Monti, J., Jr., Nardi, M.R., Finklestein, J.S., and McCoy, K.J., 2013, Hydrogeology and hydrologic conditions of the Northern Atlantic Coastal Plain aquifer system from Long Island, New York, to North Carolina (ver. 1.1, September 2015): U.S. Geological Survey Scientific Investigations Report 2013-5133, 76 p. [Also available at https://doi.org/10.3133/sir20135133.]

McCoy, K.J., Yager, R.M., Nelms, D.L., Ladd, D.E., Monti, J., Jr., and Kozar, M.D., 2015, Hydrologic budget and conditions of Permian, Pennsylvanian, and Mississippian aquifers in the Appalachian Plateaus physiographic province (ver.1.1, October 2015): U.S. Geological Survey Scientific Investigations Report 2015-5106, 77 p. [Also available at https://doi.org/10.3133/sir20155106.]

Moriasi, D.N., Arnold, J.G., Van Liew, M.W., Bingner, R.L., Harmel, R.D., and Veith, T.L., 2007, Model evaluation guidelines for systematic quantification of accuracy in watershed simulations: Transactions of the ASABE, v. 50, no. 3, p. 885-900. [Also available at https://doi.org/ $10.13031 / 2013.23153$. 
Morrissey, D.J., 1983, Hydrology of the Little Androscoggin River valley aquifer, Oxford County, Maine: U.S. Geological Survey Water-Resources Investigations Report 83-4018, 79 p. [Also available at https://doi.org/10.3133/ wri834018.]

Nash, J.E., and Sutcliffe, J.V., 1970, River flow forecasting through conceptual models part I-A discussion of principles: Journal of Hydrology (Amsterdam), v. 10, no. 3, p. 282-290. [Also available at https://doi.org/10.1016/00221694(70)90255-6.]

Nielsen, M.G., 2002, Estimated quantity of water in fractured bedrock units on Mt. Desert Island, and estimated groundwater use, recharge, and dilution of nitrogen in septic waste in the Bar Harbor area, Maine: U.S. Geological Survey Open-File Report 2002-435, 45 p. [Also available at https://doi.org/10.3133/ofr2002435.]

Nielsen, M.G., 2019, Soil-Water-Balance (SWB) model archive used to simulate potential annual recharge in Maine, 1991-2015: U.S. Geological Survey data release, https://doi.org/10.5066/P9GRP7DH.

Nielsen, M.G., and Locke, D.B., 2012, Simulation of groundwater conditions and streamflow depletion to evaluate water availability in a Freeport, Maine, watershed: U.S. Geological Scientific Investigations Report 2011-5227, 72 p. [Also available at https://pubs.usgs.gov/sir/2011/5227/.]

Nielsen, M.G., and Locke, D.B., 2015, Simulation of groundwater flow and streamflow depletion in the Branch Brook, Merriland River, and parts of the Mousam River watersheds in southern Maine: U.S. Geological Survey Scientific Investigations Report 2014-5235, 78 p. [Also available at https://doi.org/10.3133/sir20145235.]

Nielsen, M.G., and Westenbroek, S.M., 2019, Simulated 25-year median potential recharge datasets for Maine, 1991-2015: U.S. Geological Survey data release, https://doi.org/10.5066/P9052ULY.

PRISM Climate Group, Oregon State University, 2012, United States average annual precipitation, 1981-2010 (800 m; ASCII GRID): Corvallis, Oreg., Oregon State University, Northwest Alliance for Computational Science \& Engineering, digital data, accessed February 21, 2019, at http://prism.oregonstate.edu/normals/.

Reitz, M., Senay, G.B., and Sanford, W.E., 2017, Combined remote sensing and water-balance evapotranspiration estimates (SSEBop-WB) for the conterminous United States: U.S. Geological Survey data release, accessed October 2018 at https://doi.org/10.5066/F7QC02FK.

Robert G. Gerber, Inc., 1986, City of Portland-Island ground water management study: Freeport, Maine, Robert G. Gerber, Inc., 54 p., 6 apps. [Also available at https://repository.library.noaa.gov/view/noaa/8264.]
Robinson, L., and Gerber, R.G., 2007, Impact on groundwater of future development in the Hadley Point area of Bar Harbor: Portland, Maine, Stratex Inc., 21 p.

Rutledge, A.T., 2007, Update on the use of the RORA program for recharge estimation: Ground Water, v. 45, no. 3, p. 374-382. https://doi.org/10.1111/j.17456584.2006.00294.x.

Smith, E.A., and Westenbroek, S.M., 2015, Potential groundwater recharge for the State of Minnesota using the SoilWater-Balance model, 1996-2010: U.S. Geological Survey Scientific Investigations Report 2015-5038, 85 p., accessed May 2015 at https://doi.org/10.3133/sir20155038.

Soil Survey Staff, 2016, Gridded Soil Survey Geographic (gSSURGO) Database for Maine (FY16 official release, November 15, 2016): U.S. Department of Agriculture, Natural Resources Conservation Service, accessed October 28, 2017, at https://gdg.sc.egov.usda.gov/.

Tepper, D.H., Morrissey, D.J., Johnson, C.D., and Maloney, T.J., 1990, Hydrogeology, water quality, and effects of increased municipal pumpage of the Saco River Valley glacial aquifer; Bartlett, New Hampshire to Fryeburg, Maine: U.S. Geological Survey Water-Resources Investigations Report 88-4179, 113 p. [Also available at https://doi.org/ 10.3133/wri884179.]

Thornthwaite, C.W., and Mather, J.R., 1957, Instructions and tables for computing potential evapotranspiration and the water balance: Centerton, N.J., Drexel Institute of Technology, Laboratory of Climatology, Publications in Climatology, v. 10, no. 3, 311 p.

Thornton, P.E., Thornton, M.M., Mayer, B.W., Wei, Y., Devarakonda, R., Vose, R.S., and Cook, R.B., 2018, Daymet-Daily surface weather data on a 1-km grid for North America (ver. 3): Oak Ridge, Tenn., Oak Ridge National Laboratory Distributed Active Archive Center, accessed July 13, 2016, at https://doi.org/10.3334/ ORNLDAAC/1328.

Tonkin, M., and Doherty, J.E., 2009, Calibration-constrained Monte Carlo analysis of highly parameterized models using subspace techniques: Water Resources Research, v.45, no. 12,17 p. [Also available at https://doi.org/10.1029/ 2007WR006678.]

Trost, J.J., Roth, J.L., Westenbroek, S.M., and Reeves, H.M., 2018, Simulation of potential groundwater recharge for the glacial aquifer system east of the Rocky Mountains, 1980-2011, using the Soil-Water-Balance model: U.S. Geological Survey Scientific Investigations Report 2018-5080, 49 p., accessed July 2018 at https://doi.org/ 10.3133/sir20185080. 
U.S. Department of Agriculture [USDA], Natural Resources Conservation Service [NRCS], 2007, Hydrologic soil groups, chap. 7 of Hydrology: Washington, D.C., National Engineering Handbook, pt. 630, 14 p., accessed August 2018 at https://directives.sc.egov.usda.gov/. [Directly accessible at https://directives.sc.egov.usda.gov/ OpenNonWebContent.aspx? content=22526.wba.]

Welter, D.E., White, J.T., Hunt, R.J., and Doherty, J.E., 2015, Approaches in highly parameterized inversion-PEST++ version 3, a Parameter ESTimation and uncertainty analysis software suite optimized for large environmental models: U.S. Geological Survey Techniques and Methods, book 7, chap. C12, 54 p., accessed May 2018 at https://doi.org/ $10.3133 / \mathrm{tm} 7 \mathrm{C} 12$.
Westenbroek, S.M., Engott, J.A., Kelson, V.A., and Hunt, R.J., 2018, SWB version 2.0 - A Soil-Water-Balance code for estimating net infiltration and other water-budget components: U.S. Geological Survey Techniques and Methods, book 6, chap. A59, 118 p., accessed October 2018 at https://doi.org/10.3133/tm6A59.

Westenbroek, S.M., Kelson, V.A., Dripps, W.R., Hunt, R.J., and Bradbury, K.R., 2010, SWB-A modified Thornthwaite-Mather Soil-Water-Balance code for estimating groundwater recharge: U.S. Geological Survey Techniques and Methods, book 6, chap. A31, 60 p. [Also available at https://doi.org/10.3133/tm6A31.]

White, J.T., Fienen, M.N., and Doherty, J.E., 2016, A python framework for environmental model uncertainty analysis: Environmental Modelling \& Software, v. 85, p. 217-228. [Also available at https://doi.org/10.1016/ j.envsoft.2016.08.017.] 
Appendixes 1-3 


\section{Appendix 1. Details of Soil-Water-Balance Model Input for Maine}

This appendix describes the data sources and data processing of the Soil-Water-Balance (SWB) model input in more detail than is presented in the main report. The climate data, land use data, and soils data are discussed. All the values of the calibrated lookup tables (land-use lookup table and irrigation lookup table) are presented in this appendix. The model input datasets and all the information needed to run this model are available in the U.S. Geological Survey (USGS) model archive for this model (https://doi.org/10.5066/P9GRP7DH; Nielsen, 2019).

\section{Climate Data}

The DayMet version 3 gridded estimates of daily climate data from the Oak Ridge National Laboratory were used in the Maine SWB model (Thornton and others, 2018; https://daac.ornl.gov/DAYMET/guides/Daymet_V3 CFMosaics.html\#citation). These data have a spatial resolution of 1 kilometer. Daily minimum and maximum temperature and daily precipitation data from 1990 to 2015 were used for the model. The files were downloaded using the Network Common Data Form (netCDF) format on July 13, 2016. A python script was used to subset the national DayMet files to include only the geographic area needed to run the Maine SWB model.

\section{Land Use}

Land-use data for the Maine SWB model were based on the Maine Land Cover Dataset (MELCD), with modifications of water, wetland areas, and gravel pits using gSSURGO soil data. The MELCD data are based on Landsat Thematic Mapper 5 and 7 imagery from 1999 and 2000, and have a spatial resolution of 5 meters (Maine Office of Geographic Information Systems, 2006). Several of the original land-use classifications were condensed so that the final landcover dataset used had 19 land-use classes. Wetland and openwater areas were compared to wetland areas from the Natural Resources Conservation Service (NRCS) soils data (described below). If the NRCS soil unit indicated a wetland but the land use did not, the land use was assigned to a "wetlands from soils" category. Additional cleanup also was done to prevent inconsistencies in the treatment of open water between the soil and land use layer. The final land-use classes in the SWB model are listed in table 2 and are mapped in figure 3 of the report. The crosswalk between the original MELCD codes and the Maine SWB land-use codes are in table 1.1.
Table 1.1. Crosswalk between original Maine Land Cover Dataset and land-use codes used in the Maine Soil-Water-Balance model.

[Shaded cells highlight changes from the original. SWB, Soil-Water-Balance; NA, not applicable]

\begin{tabular}{|c|c|c|c|}
\hline $\begin{array}{l}\text { Original } \\
\text { code }\end{array}$ & $\begin{array}{l}\text { 5-meter grid original } \\
\text { classes (from melcd.tif) }\end{array}$ & $\begin{array}{l}\text { Final Maine } \\
\text { SWB land- } \\
\text { use codes }\end{array}$ & $\begin{array}{l}\text { Final Maine SWB } \\
\text { land-use classes }\end{array}$ \\
\hline 2 & High intensity developed & 2 & $\begin{array}{l}\text { Developed-High } \\
\text { intensity }\end{array}$ \\
\hline 3 & $\begin{array}{l}\text { Medium intensity } \\
\text { developed }\end{array}$ & 3 & $\begin{array}{r}\text { Developed- } \\
\text { Moderate }\end{array}$ \\
\hline 4 & Low intensity developed & 4 & $\begin{array}{l}\text { Developed-Low } \\
\text { intensity }\end{array}$ \\
\hline 5 & Open space developed & 5 & $\begin{array}{l}\text { Developed-Open } \\
\text { space }\end{array}$ \\
\hline 6 & Cultivated crops & 6 & Cultivated crops \\
\hline 7 & Pasture/hay & 7 & Pasture/hay \\
\hline 8 & Grassland/herbaceous & 8 & Grassland \\
\hline 9 & Deciduous forest & 9 & Deciduous forest \\
\hline 10 & Evergreen forest & 10 & Evergreen forest \\
\hline 11 & Mixed forest & 11 & Mixed forest \\
\hline 12 & Scrub/shrub & 12 & Scrub/shrub \\
\hline 13 & Wetland forest & 13 & Wetland forest \\
\hline NA & NA & 14 & $\begin{array}{l}\text { Wetlands from } \\
\text { soils }\end{array}$ \\
\hline 15 & Wetlands & 15 & Wetlands \\
\hline 16 & Roads/runways & 16 & $\begin{array}{l}\text { Roads/runways/ } \\
\text { bare rock }\end{array}$ \\
\hline 19 & Unconsolidated shore & 21 & Open water \\
\hline 20 & Bare land & 20 & Bare land \\
\hline 21 & Open water & 21 & Open water \\
\hline 22 & Blueberry field & 22 & $\begin{array}{l}\text { Blueberry bar- } \\
\text { rens }\end{array}$ \\
\hline 23 & Recent clearcut & 12 & Scrub/shrub \\
\hline 24 & Light partial cut & 11 & Mixed forest \\
\hline 25 & Heavy partial cut & 12 & Scrub/shrub \\
\hline 26 & Regenerating forest & 12 & Scrub/shrub \\
\hline 27 & Alpine & 27 & Alpine/tundra \\
\hline NA & NA & 30 & Gravel pits \\
\hline
\end{tabular}




\section{Soils Data from Natural Resources Conservation Service}

Several groups of information for running the Maine SWB model were taken from the NRCS gridded soil survey data from 2016 (NRCS gridded Soil Survey Geographic Database [gSSURGO] data; Soil Survey Staff, 2016). The gSSURGO data are a compilation of soil survey data for all counties in the country. The gSSURGO data format is a raster of soil map unit keys at a 10-meter resolution. The map unit keys link the raster cells to many attribute tables, including (among others) soil unit names, soil unit descriptions, hydrologic soil groups, drainage classes, parent material, and available water capacity.

The soil unit names and descriptions were used in comparison with the land-use data to make sure that the input grids from the gSSURGO database were not inconsistent with the land-use data (for example, to make sure that if the land-use data indicated open water in a certain area, that the gSSURGO data were not coded for a terrestrial soil type). Cleanup of the final land-use layer and hydrologic soil group layer was done to prevent these types of inconsistencies.

\section{Hydrologic Soil Groups}

Data processing of the NRCS standard hydrologic soil groups included filling in missing data (for soils with no hydrologic soil groups code assigned) and modifying the D hydrologic group.

The gSSURGO "chorizon" table was the primary source for the hydrologic soils group ("hydgrp" field). For soils that did not have a valid value for the "hydgrp" field, values were assigned based on other soils in the same county with similar geologic material descriptions ("geomdesc" field).

As described earlier in the report, the hydrologic soil groups used for the Maine SWB model were modified from the NRCS standard hydrologic soil groups. The modification included dividing the " $\mathrm{D}$ " hydrologic group (high runoff potential when wet; water movement is restricted; typically clayey textures), which in Maine includes not only flat-lying clay textured soils, but also shallow bedrock "soils," often having very high slopes. The "D" hydrologic group was divided into three subgroups based on the soil drainage class for each soil unit: "D-Ex" are the group D soils that are also excessively drained (shallow soils over bedrock, often steep slopes); "D-SoEx" are primarily soils in subdued hilly areas and often are composed of glacial till; "D-Poor" are a group of several poorly drained soil types, including glacial clay deposits, silt loam soils (farmable, but not peats), silt-loams, and silty clay loams and silt loams (no plant material or peat mentioned). Some are tidal marshes or upland areas of poor drainage (forested). The nine hydrologic soil groups used in the Maine SWB model are listed in table 3 of the report, and the distribution is mapped in figure 4 of the report.

\section{Available Water Capacity}

The available water capacity (AWC) grid was derived from the U.S. Department of Agriculture, NRCS gSSURGO for Maine, 2016 data release (Soil Survey Staff, 2016). The attribute used from the gSSURGO data for available water capacity is the "awc_r" field in the "chorizon" table, or representative available water capacity, which are given as a volume fraction. The SWB program expects AWC as inches per foot, so the values were multiplied by 12 . Some soil units did not have a value for the available water capacity. In those instances, the soil description was used to find a soil unit in the same county (if possible) with a similar geologic material description ("geomdesc") that did have a value for the available water capacity, and the value was assigned from the other soil. The available water capacity data are in units of inches of water per foot of soil (fig. 6 in the report), ranging from 0 to 7.2 inches per foot.

\section{Soil-Water-Balance Lookup Tables}

The output of the model is controlled and by many values within two lookup tables (tab-delimited text files): the landuse lookup table and the irrigation lookup table. The land-use lookup table contains values for runoff curve numbers, plant rooting depths, and maximum infiltration rates (Westenbroek and others, 2010), which are unique for every combination of land-use class and hydrologic soil group in the model. Additional lookup values for interception of rainfall on vegetation are also input and vary with vegetation type (land use). The model performs calculations to apportion water input to a cell (rainfall or snowmelt) to components of the water budget based on the input grids, daily temperature data, and the lookup table values for runoff curve, maximum infiltration rate, and plant rooting depths (fig. 2). The lookup table values for the Maine SWB model were adjusted during the calibration process; the calibrated table values for the land-use lookup table are given here in table 1.2, which is available for download at https://doi.org/10.3133/sir20195125.

The evapotranspiration calculations for the Maine SWB model were done using the optional Food and Agriculture Organization of the United Nations Drainage and Irrigation Paper 56 (FAO56) method (Allen and others, 1998;

Westenbroek and others, 2018), which requires a second lookup table, the irrigation lookup table. Although this table is used to calculate crop irrigation needs, it does so by calculating crop/land use specific transpiration and soil evaporation, which are the output desired for this application of the model. The values that control the transpiration and soil evaporation calculations were modified during the model calibration process; other values were taken from example datasets (Westenbroek and others, 2018). The final (calibrated) values for the irrigation lookup table are given in table 1.3, which is available for download at https://doi.org/10.3133/sir20195125. 


\section{References Cited}

Allen, R.G., Pereira, L.S., Raes, D., and Smith, M., 1998, Crop evapotranspiration-Guidelines for computing crop water requirements: Rome, Food and Agriculture Organization of the United Nations, Irrigation and Drainage Paper 56, 174 p. [Also available at http://www.fao.org/3/ X0490E/x0490e00.htm\#Contents.]

Maine Office of Geographic Information Systems, 2006, MELCD: Augusta, Maine Office of Geographic Information Systems, land cover map, accessed February 20, 2015, at https://www.maine.gov/megis/catalog/metadata/melcd.html.

Nielsen, M.G., 2019, Soil-Water-Balance (SWB) model archive used to simulate potential annual recharge in Maine, 1991-2015: U.S. Geological Survey data release, https://doi.org/10.5066/P9GRP7DH.

Soil Survey Staff, 2016, Gridded Soil Survey Geographic (gSSURGO) Database for Maine (FY16 official release, November 15, 2016): U.S. Department of Agriculture, Natural Resources Conservation Service, accessed October 28, 2017, at https://gdg.sc.egov.usda.gov/.
Thornton, P.E., Thornton, M.M., Mayer, B.W., Wei, Y., Devarakonda, R., Vose, R.S., and Cook, R.B., 2018, Daymet - Daily surface weather data on a 1-km grid for North America (ver. 3): Oak Ridge, Tenn., Oak Ridge National Laboratory Distributed Active Archive Center, accessed July 13, 2016, at https://doi.org/10.3334/ ORNLDAAC/1328.

Westenbroek, S.M., Engott, J.A., Kelson, V.A., and Hunt, R.J., 2018, SWB version 2.0 - A Soil-Water-Balance code for estimating net infiltration and other water-budget components: U.S. Geological Survey Techniques and Methods, book 6, chap. A59, 118 p., October 2018 at https://doi.org/ 10.3133/tm6A59.

Westenbroek, S.M., Kelson, V.A., Dripps, W.R., Hunt, R.J., and Bradbury, K.R., 2010, SWB-A modified Thornthwaite-Mather Soil-Water-Balance code for estimating groundwater recharge: U.S. Geological Survey Techniques and Methods, book 6, chap. A31, 60 p. [Also available at https://doi.org/10.3133/tm6A31.] 


\section{Appendix 2. Details of Soil-Water-Balance Model Calibration Information}

This appendix includes information on the parameters used for the land-use lookup table and the irrigation lookup table, and the recharge, runoff, and evapotranspiration observations used during the calibration. The parameter information includes whether the parameter was adjusted during the final calibration and the final calibration values used for each parameter. Also included is information on the Monte Carlo runs used to calculate the standard deviation on the median potential recharge grid.

\section{Parameters}

The model calibration used values from the land-use lookup table and the irrigation table as parameters. The individual values for the land-use lookup table entries for runoff curve numbers, maximum potential recharge, rooting depths, and interception values were treated as parameters and are included in table 2.1, which is available for download at https://doi.org/10.3133/sir20195125. The irrigation table parameters included 13 individual values for the plantgrowth coefficients $\left(\mathrm{K}_{\mathrm{cb}}\right)$ and 15 values that were multipliers for sections of the irrigation table. These multipliers acted on an initial set of table values. The irrigation parameters and a description of each are included in table 2.2, which is available for download at https://doi.org/10.3133/sir20195125. The land-use parameters are a one-for-one substitution of values for the land-use lookup table, but the irrigation table parameters include several multipliers that act on blocks of values in the irrigation lookup table, as well as some values that are direct substitutions for values in the irrigation lookup table.

\section{Observations}

The development of the observations for the model calibration included an extensive analysis of streamflow data for the recharge and runoff observations for each of the calibration watersheds, described below. The model calibration also used annual evapotranspiration observations for each of the calibration watersheds, which are described as well.

\section{Analysis of Streamflow Data for Calibration Targets}

The annual hydrograph for each gage location was separated into a base flow and direct runoff component using nine hydrograph separation techniques (table 2.3). Each base flow-separation technique uses different methods of identifying the base flow versus direct runoff components of flowsome assign a relatively larger portion of flow to base flow (recharge), some less. None of them can exactly represent the movement of water into and out of bank storage, which is an important process that often occurs on a shorter time scale than represented in the daily streamflow data that is used by most hydrograph separation techniques, and there is no consensus on which method most accurately achieves this division of flow, as it varies with watershed size and other factors (Risser and others, 2005). The Rorabaugh method, as implemented in the recession-curve displacement method RORA algorithm (Rorabaugh, 1964; Rutledge, 1998) incorporates more site-specific detail and event-based processes than other methods (Barlow and others, 2015; Risser and others, 2005). However, Risser and others (2005) found that the RORA method produced values greater than direct measurements using lysimeters. In a comparison of methods for this study, the RORA method yielded estimates that were often significantly higher than other methods, and less water was available for direct runoff. During initial calibration runs using only RORA as calibration targets, the Soil-Water-Balance

Table 2.3. Base flow-separation techniques used for annual recharge and runoff calculations.

\begin{tabular}{ll}
\hline \multicolumn{1}{c}{ Method } & \multicolumn{1}{c}{ Reference } \\
\hline Base Flow Index-Standard & Wahl and Wahl, 1995; Institute of Hydrology, 1980a, b \\
Base Flow Index - Modified & Wahl and Wahl, 1995; Institute of Hydrology, 1980a, b \\
HYSEP_Fixed Interval & Sloto and Crouse, 1996; Pettyjohn and Henning, 1979 \\
HYSEP_Sliding Interval & Sloto and Crouse, 1996; Pettyjohn and Henning, 1979 \\
HYSEP_Local Minimum & Sloto and Crouse, 1996; Pettyjohn and Henning, 1979 \\
PART & Rutledge, 1998 \\
RORA and RECESS & Rorabaugh, 1964; Rutledge, 1998 \\
SWAT Bflow (Digital Filter One Parameter) & Arnold and others, 1995; Arnold and Allen, 1999 \\
Eckhardt Digital Filter, Two Parameter & Eckhardt, 2005; Eckhardt, 2008 \\
\hline
\end{tabular}


(SWB) model was unable to reproduce the division of water into the two hydrograph components without using unrealistic values for many of the lookup table parameters. Therefore, the calibration targets chosen for this study are calculated as the median value of the nine methods, which is intended to average out the estimation inaccuracies inherent in each method.

Besides providing an averaged estimate of recharge and direct runoff, the use of so many different estimates enabled a mean and variance to be calculated, which was used to generate initial weights on the calibration targets (see below). The U.S. Geological Survey Groundwater Toolbox (Barlow and others, 2015) software package (version 1.3) was used to download and process the streamflow data for each streamgage location and compute the annual base flow and direct runoff values. A table of the annual mean base flow and direct runoff estimates and the variances for each year are given in table 2.4, which is available for download at https://doi.org/10.3133/sir20195125.

\section{Evapotranspiration Observations for Model Calibration}

The third set of calibration targets consisted of annual evapotranspiration (ET) across each watershed. Observations of ET were obtained from Reitz and others (2017), who have published monthly ET estimates for the conterminous United States based on remote sensing data (data downloaded from https://www.sciencebase.gov/catalog/item/ $59 \mathrm{~d} 3 \mathrm{~d} 13 \mathrm{ce} 4 \mathrm{~b} 05 \mathrm{fe} 04 \mathrm{cc} 3 \mathrm{~d} 278$ on October 10, 2018). The original data are gridded at a 90 -meter cell size. The monthly grids were summed for each year of the calibration period (2000-12) to get an annual grid, and the average value of annual ET over each watershed was calculated to use as the annual ET observation value. The annual values of average ET for each year and each watershed are given in table 2.5, available for download at https://doi.org/ 10.3133/ sir20195125.

The model calibration used all the observations from 2000 through 2012, but because the year 2000 is a year that sets up the snow and soil moisture storage for the first calibration year (2001), it is included in the calibration data but given zero weight in the parameter estimation process. The discussion of the selection and modification of weights is given in the body of the report. The final values are listed in table 2.6, which is available for download at https://doi.org/10.3133/ $\operatorname{sir} 20195125$.

\section{References Cited}

Arnold, J.G., Allen, P.M., Muttiah, R., and Bernhardt, G., 1995, Automated base flow separation and recession analysis techniques: Ground Water, v. 33, no. 6, p. 1010-1018. [Also available at https://doi.org/10.1111/j.17456584.1995.tb00046.x.]
Arnold, J.G., and Allen, P.M., 1999, Automated methods for estimating baseflow and ground water recharge from streamflow records: Journal of the American Water Resources Association, v. 35, no. 2, p. 411-424. [Also available at https://doi.org/10.1111/j.1752-1688.1999.tb03599.x.]

Barlow, P.M., Cunningham, W.L., Zhai, T., and Gray, M., 2015, U.S. Geological Survey groundwater toolbox, a graphical and mapping interface for analysis of hydrologic data (version 1.0)-User guide for estimation of base flow, runoff, and groundwater recharge from streamflow data: U.S. Geological Survey Techniques and Methods, book 3, chap. B10, 27 p., accessed October 2017 at https://doi.org/ $10.3133 / \mathrm{tm} 3 \mathrm{~B} 10$.

Eckhardt, K., 2005, How to construct recurvsive digital filters for base flow separation: Hydrological Processes, v. 19, no. 2, p. 507-515. [Also available at https://doi.org/ 10.1002/hyp.5675.]

Eckhardt, K., 2008, A comparison of base flow indices, which were calculated with seven different base flow separation methods: Journal of Hydrology (Amsterdam), v. 352, no. 1-2, p. 168-173. [Also available at https://doi.org/ 10.1016/j.jhydrol.2008.01.005.]

Institute of Hydrology, 1980a, Research report, v. 1 of Low flow studies: Wallingford, United Kingdom, Institute of Hydrology, 42 p.

Institute of Hydrology, 1980b, Catchment characteristic estimation manual, v. 3 of Low flow studies: Wallingford, United Kingdom, Institute of Hydrology, 27 p.

Pettyjohn, W.A., and Henning, R., 1979, Preliminary estimate of ground-water recharge rates, related streamflow and water quality in Ohio: Columbus, Ohio State University, Water Resources Center Project Completion Report $552,323 \mathrm{p}$.

Reitz, M., Senay, G.B., and Sanford, W.E., 2017, Combined remote sensing and water-balance evapotranspiration estimates (SSEBop-WB) for the conterminous United States: U.S. Geological Survey data release, accessed October 2018 at https://doi.org/10.5066/F7QC02FK.

Risser, D.W., Gburek, W.J., and Folmar, G.J., 2005, Comparison of methods for estimating ground-water recharge and base flow at a small watershed underlain by fractured bedrock in the eastern United States: U.S. Geological Survey Scientific Investigations Report 2005-5038, 31 p. [Also available at https://doi.org/10.3133/ sir20055038.]

Rorabaugh, M.I., 1964, Estimating changes in bank storage and ground-water contribution to streamflow: International Association of Scientific Hydrology, v. 63, p. 432-441. 
Rutledge, A.T., 1998, Computer programs for describing the recession of ground-water discharge and for estimating mean ground-water recharge and discharge from streamflow records-Update: U.S. Geological Survey Water-Resources Investigations Report 98-4148, 43 p. [Also available at https://pubs.usgs.gov/wri/wri984148/.]

Sloto, R.A., and Crouse, M.Y., 1996, HYSEP-A computer program for streamflow hydrograph separation and analysis: U.S. Geological Survey Water-Resources Investigations Report 96-4040, 54 p. [Also available at https://water.usgs.gov/software/HYSEP/code/doc/ hysep.pdf.]

Wahl, K.L., and Wahl, T.L., 1995, Determining the flow of Comal Springs at New Braunfels, Texas, in Proceedings of Texas Water 95, August 16-17, 1995, San Antonio, Tex.: American Society of Civil Engineers, p. 77-86. 


\section{Appendix 3. Annual Values of Modeled Recharge, Runoff, Evapotranspiration, and Precipitation for Calibration Watersheds, 1991-2015}

This appendix contains all the model-derived values of annual precipitation, recharge, runoff, and evapotranspiration for each calibration watershed, for the whole simulation period (1991-2015; table 3.1, available for download at https://doi.org/10.3133/sir20195125). 
For more information about this report, contact: Director, New England Water Science Center U.S. Geological Survey 331 Commerce Way, Suite 2

Pembroke, NH 03275

dc_nweng@usgs.gov or visit our website at https://www.usgs.gov/centers/new-england-water

Publishing support provided by the Pembroke and Rolla Publishing Service Centers 


\section{$\frac{\mathbb{2}}{3}$}

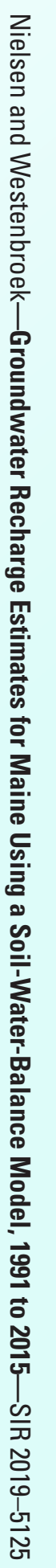

